University of Nebraska - Lincoln

DigitalCommons@University of Nebraska - Lincoln

\title{
9-27-2012
}

\section{The geologic records of dust in the Quaternary}

Daniel R. Muhs

Follow this and additional works at: https://digitalcommons.unl.edu/usgsstaffpub

Part of the Geology Commons, Oceanography and Atmospheric Sciences and Meteorology Commons, Other Earth Sciences Commons, and the Other Environmental Sciences Commons

This Article is brought to you for free and open access by the US Geological Survey at DigitalCommons@University of Nebraska - Lincoln. It has been accepted for inclusion in USGS Staff -- Published Research by an authorized administrator of DigitalCommons@University of Nebraska - Lincoln. 
Review Article

\title{
The geologic records of dust in the Quaternary
}

\author{
Daniel R. Muhs \\ US Geological Survey, MS 980, Box 25046, Federal Center, Denver, CO 80225, USA
}

\section{A R T I C L E I N F O}

\section{Article history:}

Available online 27 September 2012

\section{Keywords:}

Dust

Loess

Lake sediments

Soils

Marine sediments

Ice cores

\begin{abstract}
A B S T R A C T
Study of geologic records of dust composition, sources and deposition rates is important for understanding the role of dust in the overall planetary radiation balance, fertilization of organisms in the world's oceans, nutrient additions to the terrestrial biosphere and soils, and for paleoclimatic reconstructions. Both glacial and non-glacial processes produce fine-grained particles that can be transported by the wind. Geologic records of dust flux occur in a number of depositional archives for sediments: (1) loess deposits; (2) lake sediments; (3) soils; (4) deep-ocean basins; and (5) ice sheets and smaller glaciers. These archives have several characteristics that make them highly suitable for understanding the dynamics of dust entrainment, transport, and deposition. First, they are often distributed over wide geographic areas, which permits reconstruction of spatial variation of dust flux. Second, a number of dating methods can be applied to sediment archives, which allows identification of specific periods of greater or lesser dust flux. Third, aeolian sediment particle size and composition can be determined so that dust source areas can be ascertained and dust transport pathways can be reconstructed. Over much of the Earth's surface, dust deposition rates were greater during the last glacial period than during the present interglacial period. A dustier Earth during glacial periods is likely due to increased source areas, greater aridity, less vegetation, lower soil moisture, possibly stronger winds, a decreased intensity of the hydrologic cycle, and greater production of dust-sized particles from expanded ice sheets and glaciers.
\end{abstract}

Published by Elsevier B.V.

\section{Contents}

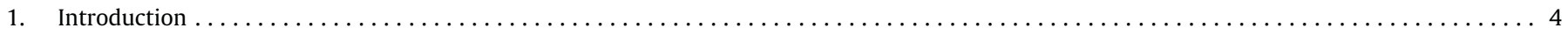

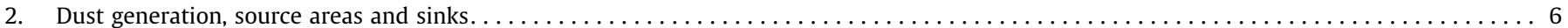

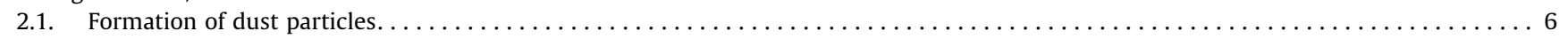

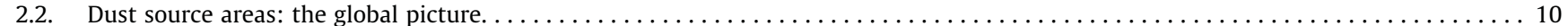

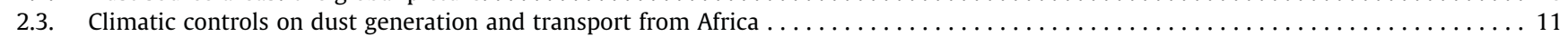

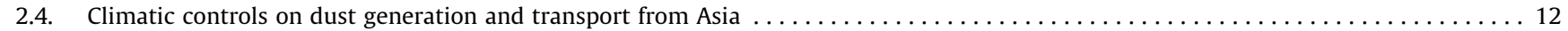

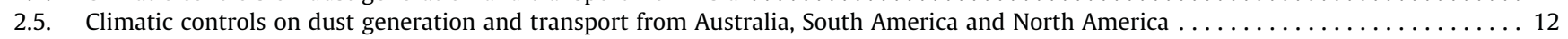

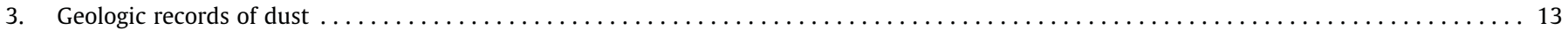

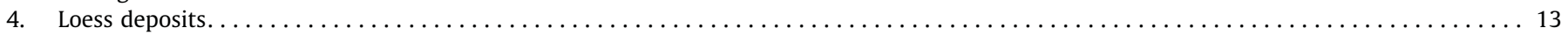

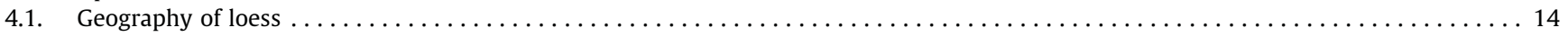

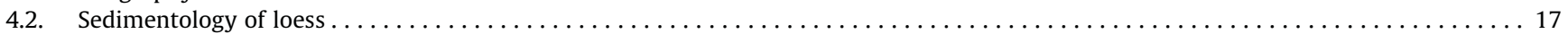

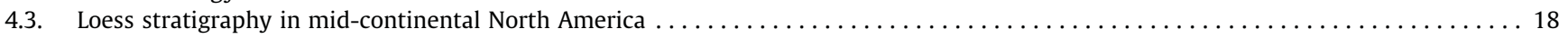

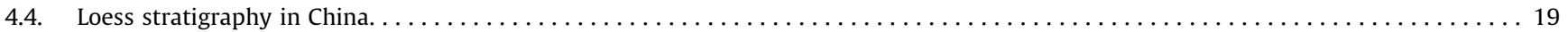

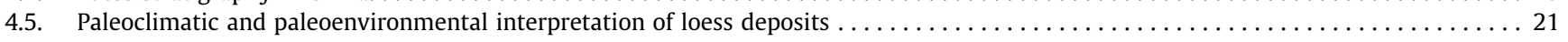

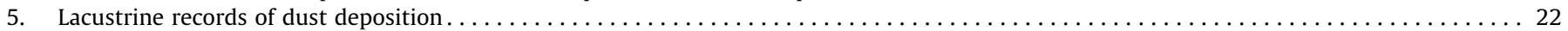

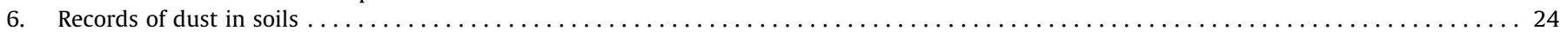

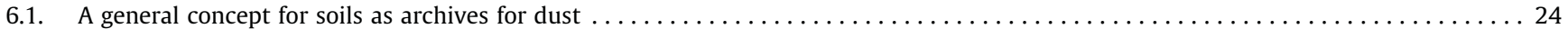

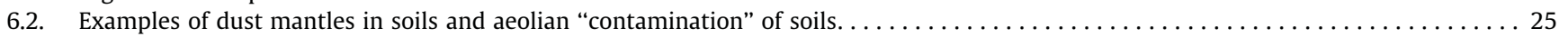

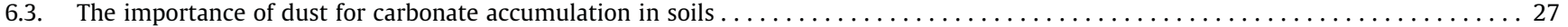

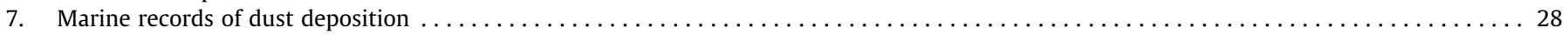

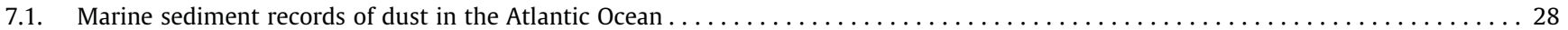

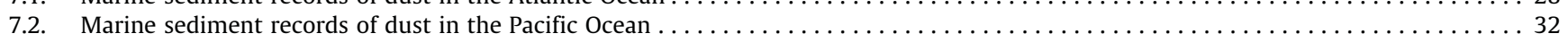

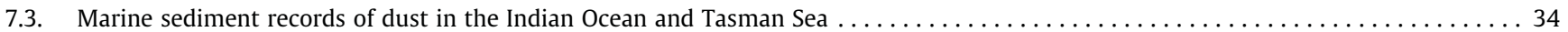




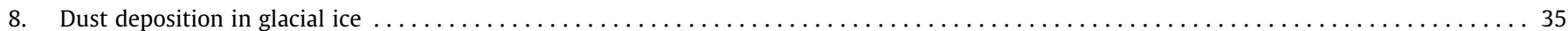

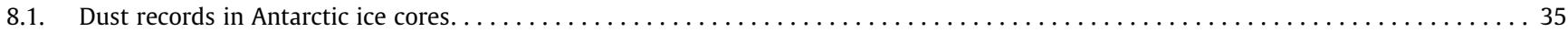

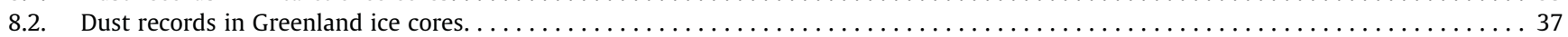

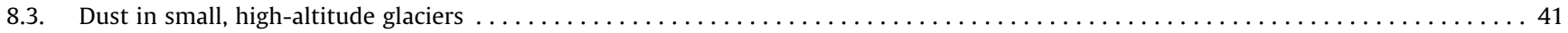

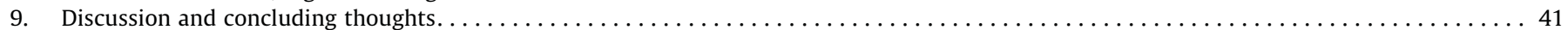

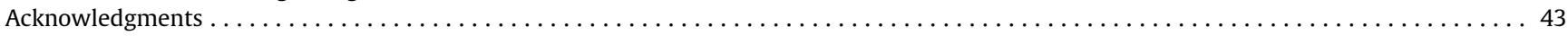

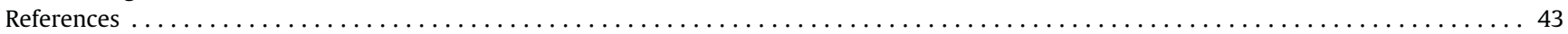

"I wish those dusty Santa Ana winds would come and carry me out to sea..."

-from "Santa Ana Winds," written by Steve Goodman, Mary Gaffney and Mike Jordan, published by Big Ears Music, Inc. o/b/o itself E' Red Pajamas Music (ASCAP).

\section{Introduction}

There has been an increasing awareness of the significance of mineral dust in the Earth's physical systems and biosphere. This new interest in dust is highly interdisciplinary, spanning the fields of geology, biology, and atmospheric sciences, and even integrating work from the extraterrestrial scientific community. In recent reviews, Kohfeld and Harrison (2000, 2001), Harrison et al. (2001), Tegen (2003), Goudie and Middleton (2006), Kohfeld and Tegen (2007), Maher et al. (2010) and Shao et al. (2011) summarize a number of important impacts of mineral dust on the Earth-atmosphere system. Because dust can have high concentrations in the atmosphere, it can change the overall planetary radiation balance through direct effects on radiation at both solar (shortwave) and terrestrial (longwave) portions of the electromagnetic spectrum (Tegen, 2003). Authors of the 2007 IPCC report specifically identify dust as an important component in the global radiation balance (Forster et al., 2007). Fine-grained dust can be a significant carrier of Fe and phytoplankton blooms can occur in the ocean after dustderived Fe fertilization (Falkowski et al., 1998; Jickells et al., 2005; Mahowald et al., 2009). Such blooms can result in significant carbon dioxide drawdown from the atmosphere, thus altering the planetary carbon balance. An often-overlooked process is that dust can have important effects on the biogeochemical cycle of terrestrial ecosystems, adding nutrients to soils and the vegetation they support. Numerous studies now document evidence for far-traveled dust additions to soils (Rex et al., 1969; Jackson et al., 1971; Birkeland, 1999; Kurtz et al., 2001; Reynolds et al., 2001; Muhs et al., 2007a, 2007b, 2010). Finally, dust can have tremendous importance in paleoclimate studies. Because dust is entrained and transported by wind, geologic records of dust are some of the few direct indicators we have of atmospheric circulation in the past. Thus, dust records of the past are of considerable importance in testing general circulation models (GCMs) (Mahowald et al., 1999, 2006).

This review summarizes some of what is known about geologic records of dust. Dust monitoring and dust trapping programs have given us valuable records of modern dust flux. Some of the longer dust monitoring and trapping programs include those on Barbados and in Florida (Prospero, 1999; Prospero and Nees, 1977, 1986; Prospero and Lamb, 2003) and those in the southwestern United States (Gile and Grossman, 1979; Reheis, 2003, 2006; Reheis and Kihl, 1995). Nevertheless, although these programs constitute some of the longer direct measurement records we have, the length of such records is on a timescale of decades. In order to understand the links between dust flux and major climate changes of the Quaternary, it is necessary to examine geologic records of fine-grained particle deposition by the wind.
In this paper, the use of the word dust follows that of Pye (1987), who defines dust as a suspension of solid particles in a gaseous medium. A corollary to this is that the term dust also refers to deposits of such particles. Crucial in this definition is the term suspension, which refers to the mode of transport in the atmosphere. Dust particles are those that have been entrained by the wind and are transported horizontally without contact with the ground surface. Suspension requires a vertical component of wind flow, such that grains are kept aloft as long as the vertical component of the wind exceeds the particle settling velocity (Pye, 1987). This distinguishes dust particles from larger grains, such as sand, that can also be transported by the wind. Sand-sized particles, when transported by the wind, do so largely by saltation, a bouncing type of particle motion with periodic contact with the ground surface, or by surface creep, where there is constant contact with the ground surface during horizontal transport. Pye (1987) distinguishes between short-term suspension, which is that experienced by particles that have diameters of $\sim 70 \mu \mathrm{m}$ to $\sim 20 \mu \mathrm{m}$ and longterm suspension, which is that experienced primarily by particles with diameters $<20 \mu \mathrm{m}$. Thus, grains larger than $\sim 20 \mu \mathrm{m}$ tend to be deposited within $\sim 30 \mathrm{~km}$ of their source, whereas grains $<20 \mu \mathrm{m}$ and particularly those $<10 \mu \mathrm{m}$ are capable of long-range transport (LRT), up to thousands of kilometers away from their source.

There are important exceptions to these theoretical concepts about dust particle sizes and distance of transport in long-term suspension. Betzer et al. (1988) document the presence of mineral particles $>75 \mu \mathrm{m}$ diameter that have been transported to the Pacific Ocean, more than $10,000 \mathrm{~km}$ from their sources in Asia. Off the west coast of Africa, from studies of dust traps that are $\sim 300-$ $450 \mathrm{~km}$ from the closest possible coastal sources, Ratmeyer et al. (1999) report that mean particle sizes range from $\sim 10$ to $\sim 20 \mu \mathrm{m}$, but particles as large as $\sim 55 \mu \mathrm{m}$ were also found. Stuut et al. (2005) made shipboard dust collections, also off the coast of western Africa, and report modal particle sizes of $8-42 \mu \mathrm{m}$, but also find a significant number of particles with diameters $>100 \mu \mathrm{m}$.

The term aerosol is sometimes used when referring to dust, particularly LRT dust, commonly those particles with diameters $<10 \mu \mathrm{m}$. In its broadest sense, aerosol refers to a suspension of fine liquid and/or solid particles dispersed within a gaseous medium (Prospero et al., 1983). Thus, aerosols can be mineral particles, but also include volcanic glass particles, sea salt, hydrocarbons, smoke, mist, fumes and fog. Aerosols that are not mineral particles are not included in this review.

There is often some confusion about the term "dust" and the term "loess." Loess is defined as silt-dominated sediment that has been entrained, transported, and deposited by the wind (see reviews by Pye $(1987,1995)$ and Muhs (2007, in press)). Loess can be recognized in the field as a distinctive, terrestrial sedimentary body and can be mapped as a geologic unit. Its thickness, however, is highly variable and can range from a few centimeters to several hundred meters. Loess occupies an intermediate position in a continuum of aeolian sediments (from sand to LRT dust), with a mean particle size that is smaller than windblown sand (2$0.05 \mathrm{~mm}$ ), but coarser than LRT dust (typically $<10-20 \mu \mathrm{m}$ ). 


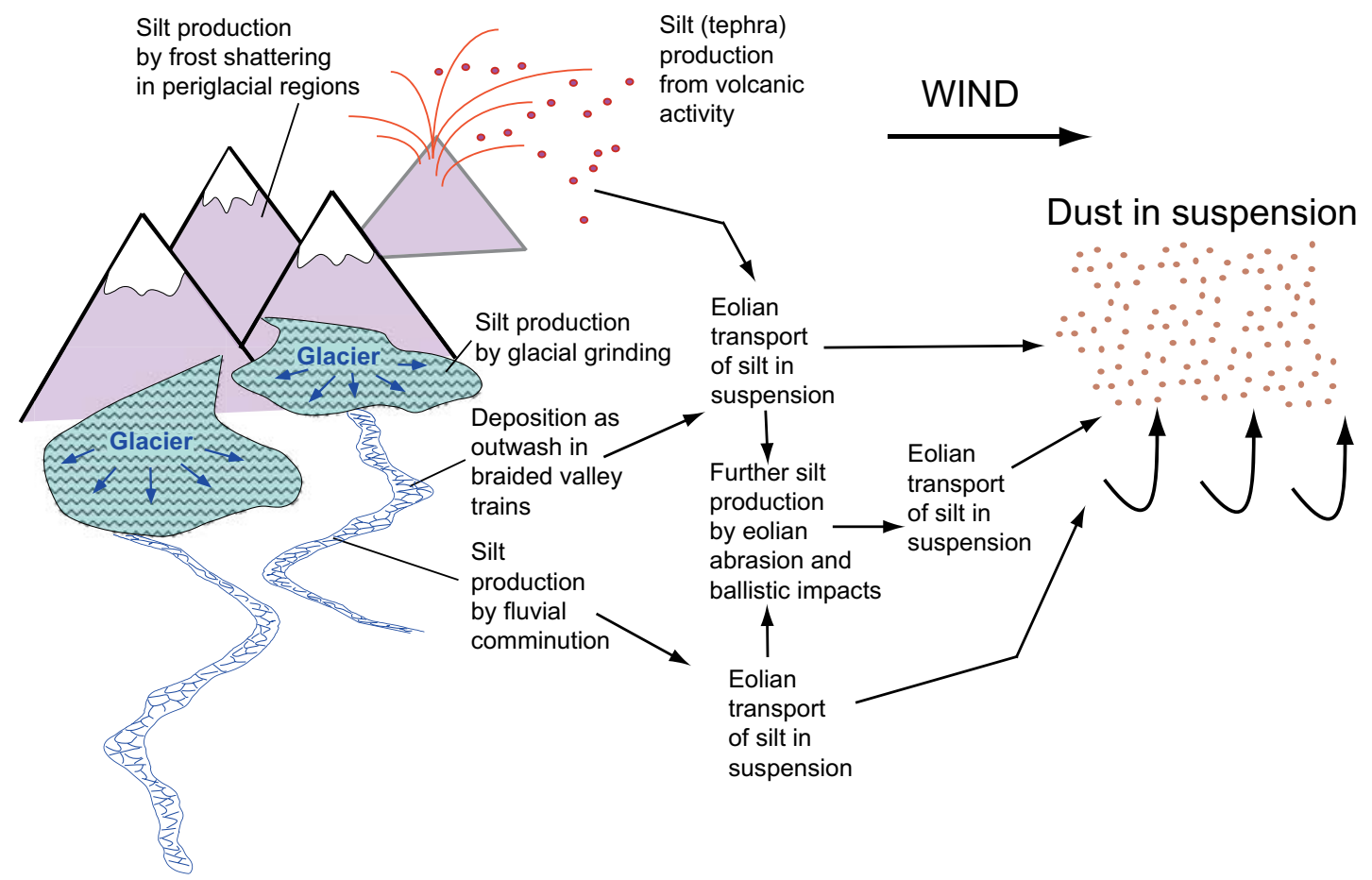

Fig. 1. Simplified model of fine (silt-sized) particle production to generate dust in glacial environments. Modified from Muhs and Bettis (2003).

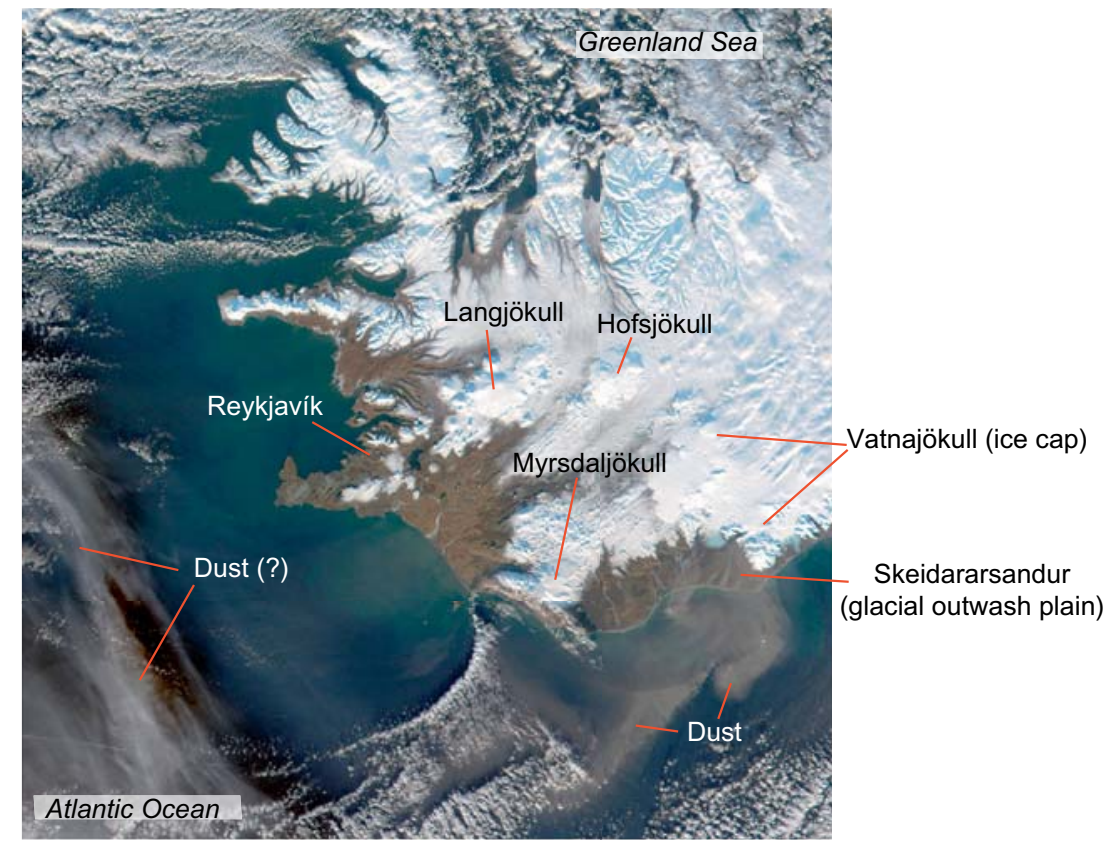

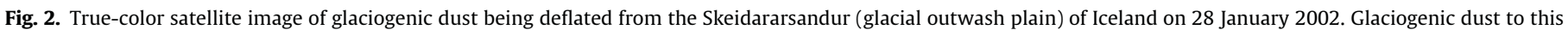

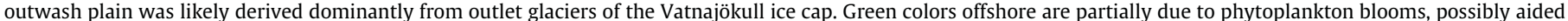
by dust fertilization. MODIS image from the Terra satellite, provided courtesy of Jacques Descloitres, MODIS Land Rapid Response Team, NASA/GSFC.

Commonly, loess contains $60-90 \%$ silt-sized (50-2 $\mu$ m diameter) particles, but also usually small percentages of sand (particles $>50 \mu \mathrm{m})$ and clay $(<2 \mu \mathrm{m})$. Thus, using Pye's (1987) general concepts of modes of aeolian transport and particle size, loess sediments at a given site might include a suite of particles, some of which were transported by saltation, some by short-term suspension, and some by long-term suspension. Because almost all loess deposits contain significant amounts of particles with diameters
$<20 \mu \mathrm{m}$, loess deposits can be considered to at least contain dust particles, and some distal loess deposits are composed dominantly of dust particles.

In this review, no restrictions are put on the mode of origin of mineral dust particles, their source areas, their distance of transport, or their ultimate "sinks" or final loci of deposition. Indeed, the focus of the review is on the variety of naturally occurring sediment sinks that constitute the geologic record of dust deposition. 


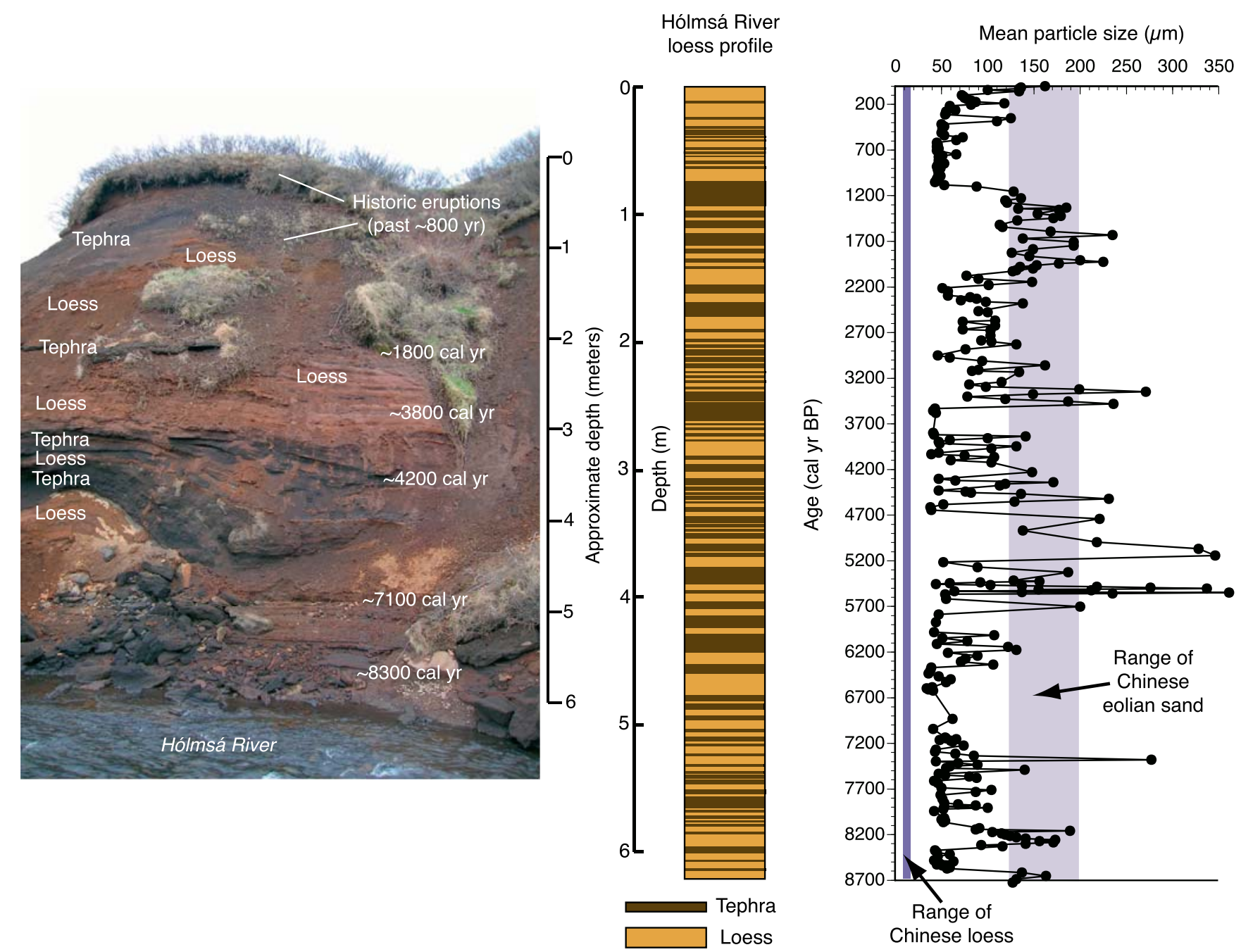

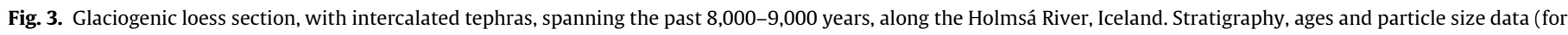

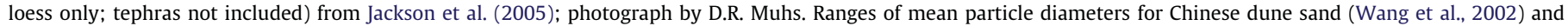
Chinese loess (Lu et al., 2001) are shown for comparison.

Major themes explored here are the advantages and disadvantages of various dust sinks as geologic records for paleoclimatic reconstruction.

\section{Dust generation, source areas and sinks}

\subsection{Formation of dust particles}

Dust particles can be generated naturally by a wide variety of processes on the Earth. In a simplified fashion, these processes can be classified into four groups: (1) volcanogenic, (2) physical processes of larger particle reduction, (3) chemical processes of larger particle reduction, and (4) inheritance from fine-grained rocks. Fine-grained particles can be produced directly by volcanic processes as tephra or ash. Although many particles in volcanic ash are too coarse-grained to be considered dust, some are of fine-silt size and even clay size. Because these particles are ejected from a volcanic source vent directly into the atmosphere, they do constitute a form of "dust" although the initial emplacement into the atmosphere is not by the transporting force of the wind. Nevertheless, once volcanic ash has entered the atmosphere, which is almost immediately, wind becomes a very important determinant of how ash is transported and to where it is deposited. Ash trans- port over more than a thousand kilometers has been documented (Carey and Sigurdsson, 1980), although this is largely from particles that have been ejected into the stratosphere. Most ash within the troposphere is deposited within a few hundreds to a kilometer of its source (Grainger and Highwood, 2003). Large eruptions in historic time have had significant effects on the Earth's overall temperature through albedo increases that have reduced the amount of incoming short-wave solar radiation, similar to effects modeled for non-volcanic dust. There is clear evidence of overall cooling due to radiative forcing from the 1982 El Chichón eruption and even more dramatically from the 1991 Mount Pinatubo eruption (Minnis et al., 1993; Grainger and Highwood, 2003). Finally, both primary and reworked tephra particles can be an important component of loess, as documented in South America (Zárate, 2003, 2007), New Zealand (Eden and Hammond, 2003), Alaska (Muhs et al., 2004), Iceland (Jackson et al., 2005), and Japan (Matsu'ura et al., 2011).

Most mineral dust is produced by coarse particle reduction by either physical or chemical processes. For more than a century, loess has been considered to be produced primarily by physical reduction of coarse particles through glacial grinding (Fig. 1). As an ice sheet or valley glacier moves over rock of any kind-igneous, sedimentary or metamorphic-silt-sized particles are produced efficiently by grinding. In regions that have valleys with glaciers and 


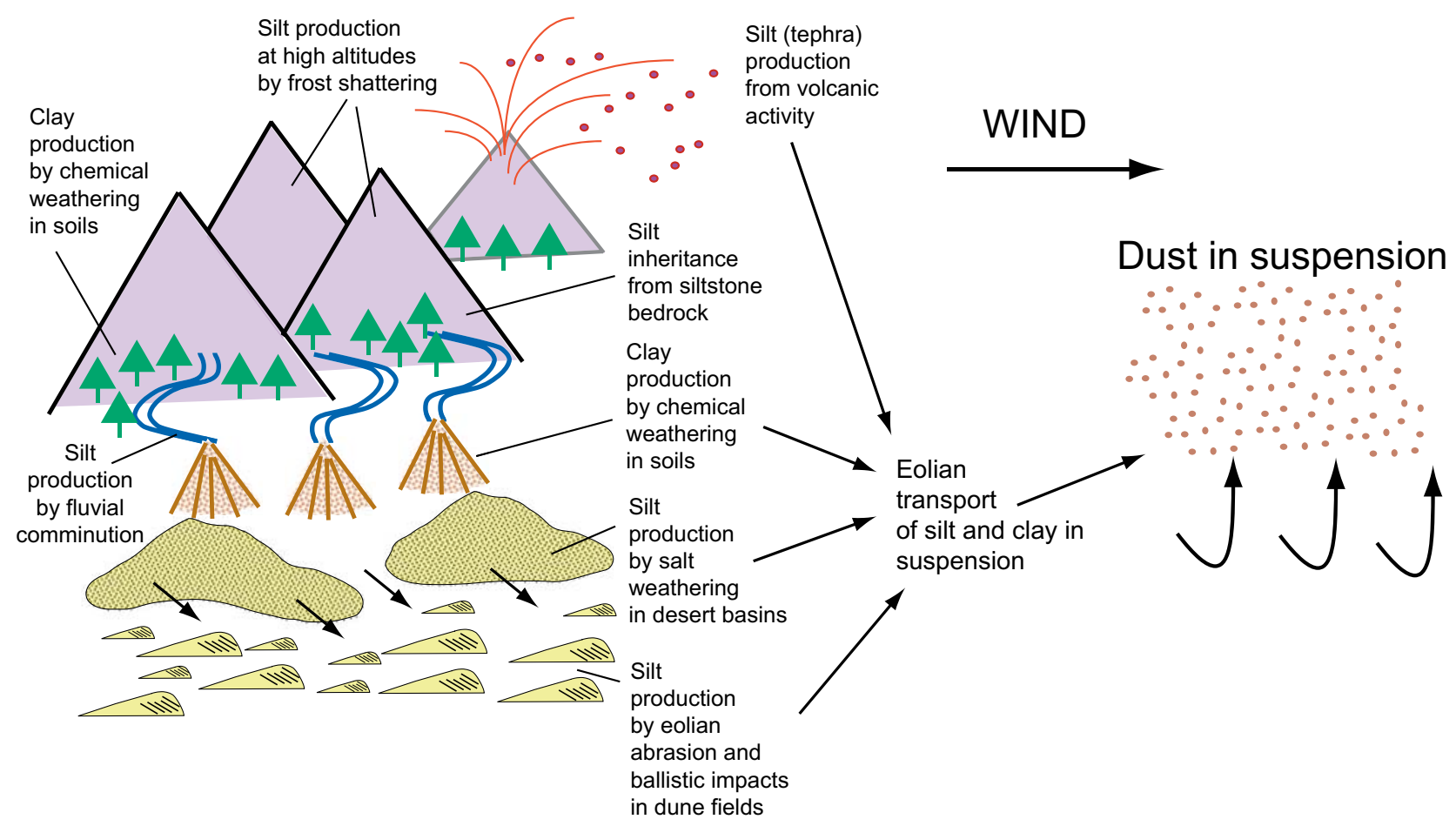

Fig. 4. Simplified model of fine (silt-and-clay-sized) particle production to generate dust in non-glacial environments. Modified from Muhs and Bettis (2003).

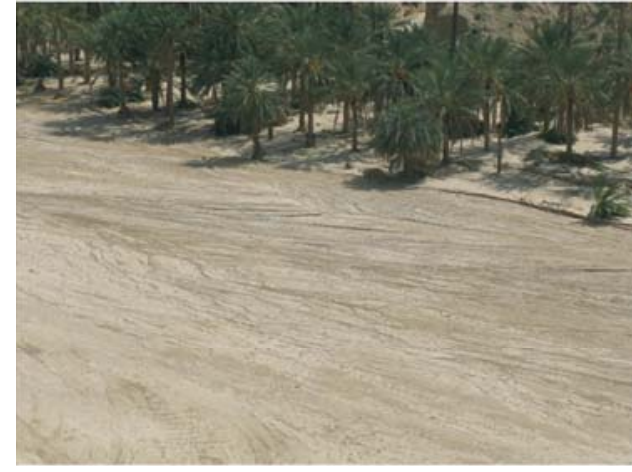

(a) Dry wash sediments in Oued el Khanga, draining the Atlas Mountains

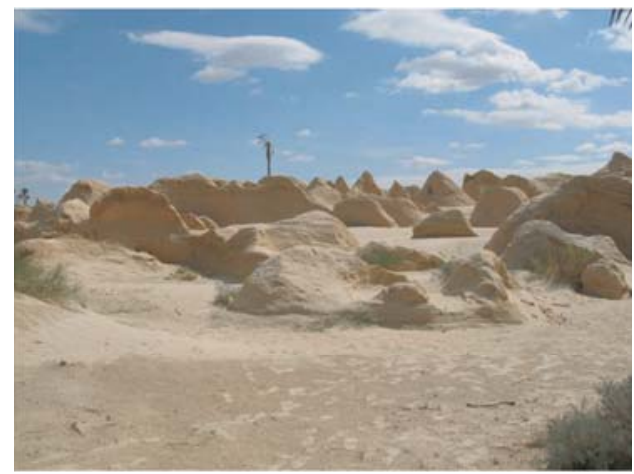

(b) Yardangs, Dbebcha

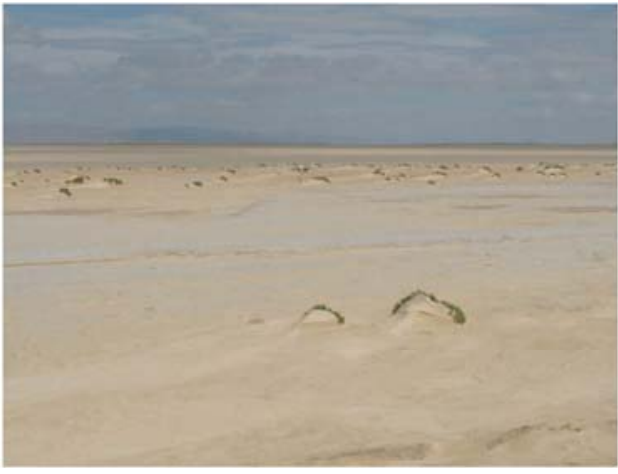

(c) Nebkas (coppice dunes) on Chott el Jerid (playa)

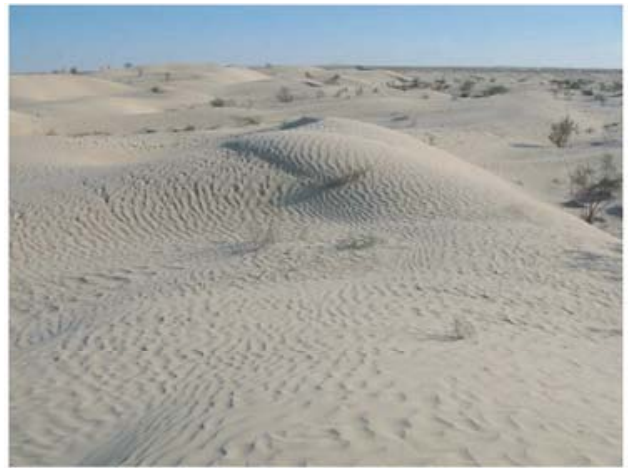

(d) Active dune sand, Grand Erg Oriental

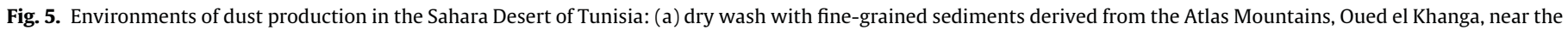

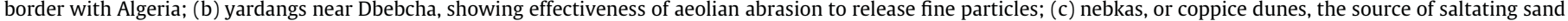

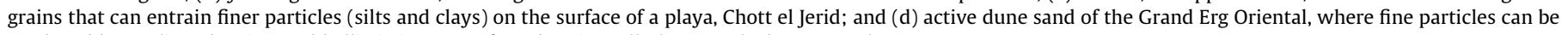
produced by aeolian abrasion and ballistic impacts of sand grains. All photographs by D.R. Muhs. 


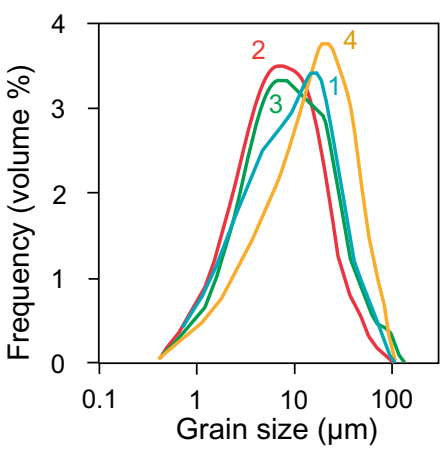

1. Off central Morocco

2. Off the Canary

Islands

3. Off southern

Morocco

4. Off the Morocco-

Mauritania border

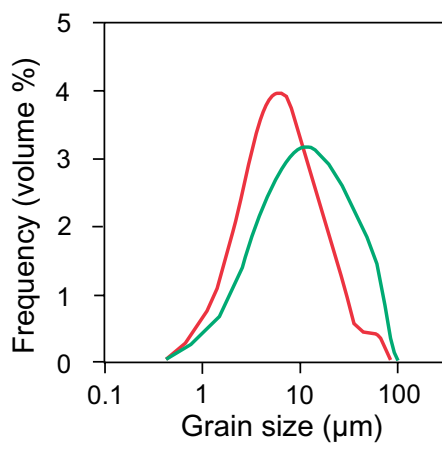

Off West Africa,

south of Morocco

Fig. 6. Grain size distribution (done by laser particle size analyses) of modern dust collected onboard a ship off the coast of Africa. Data from Stuut et al. (2005).

adjacent valleys with no glaciers, fine-grained sediment yields are much higher in glaciated valleys (Hallet et al., 1996; Wada et al., 2011). Although much silt-sized material is produced in this fashion, further particle size reduction can occur by fluvial comminution as particles are carried away from glaciers by valley trains (streams carrying glacial outwash). Good examples of glaciogenic silt production can be found today where glaciers still exist, such as in Svalbard, Iceland, Alaska, and Canada. In Iceland, modern ice caps (such as the Vatnajökull) are analogs for the larger ice sheets that once covered North America and Eurasia; outwash plains such as the Skeidararsandur are analogs for the outwashfilled valley trains and plains that drained those ice sheets (Fig. 2). As aeolian entrainment from glacial river valleys commences, more particle size reduction can take place by aeolian abrasion and ballistic impacts (Fig. 1). Thus, fine-grained particles in a glacial setting can be produced by physical reduction of coarser particles through glacial, fluvial and aeolian processes. As a consequence, loess derived from glacial settings will have a range of particle sizes, but with many falling within the range of coarse and medium silt, and including some fine silt that can be considered dust-sized particles (Fig. 3).

It has been observed that there is little loess that accumulates in non-glacial settings, such as desert regions (Tsoar and Pye, 1987). Thus, some investigators have proposed that glacial grinding is the only efficient means by which silt-sized particles can be produced (Smalley, 1966, 1995; Smalley and Vita-Finzi, 1968). Experimental work has shown, however, that although glacial grinding is indeed a significant method of silt particle production, other processes, including fluvial and aeolian abrasion, are surprisingly efficient mechanisms of silt particle production (Smith et al., 2002; Wright and Smith, 1993; Wright et al., 1998; Wright, 2001a,b). In non-glacial settings, such as many of the world's desert regions, fluvial comminution in stream valleys, aeolian abrasion and ballistic impacts in dune fields, and salt weathering in playas and on alluvial fans have all been shown to produce silt-sized particles (Fig. 4). For example, in the northern part of the Saharan Desert in southern Tunisia, fluvial comminution can take place in large wadis or dry washes that drain major mountain ranges such as the Atlas Mountains (Fig. 5a). Aeolian abrasion of landforms can yield fine-grained particles and the evidence of this process can take the form of residual yardangs (Fig. 5b). Fine-grained sediments, derived from fluvial erosion of desert mountain ranges, accumulate in topographic depressions where playas (or "chotts") occur. Although these fine-grained particles are often flocculated or cemented by salts, they can be broken apart and entrained by saltating sand-sized grains if dunes occur on or near the playas (Fig. 5c). Fine-grained particles can also be produced within dune fields themselves, by aeolian abrasion of coarse particles and ballistic impacts (Fig. 5d). Indeed, dune-field generation of finegrained particles has recently been proposed as a major source for at least the coarsest fraction of desert loess (Crouvi et al., 2008, 2010). In addition, however, at high altitudes or high latitudes in desert regions, coarse particles can be reduced to silt size through frost shattering, with the volumetric expansion of water upon freezing. Collectively, these processes can generate significant amounts of silt-sized particles, some of them dust-sized, in non-glacial settings.

Despite the importance of physical processes of silt production, much LRT dust consists of clay-sized particles with diameters less than $2 \mu \mathrm{m}$, or clay-sized material. For example, Stuut et al. (2005) show that modern dust collected off the African coast consists dominantly of particles less than $20 \mu \mathrm{m}$ diameter (Fig. 6). LRT dust derived from Africa, carried across the Atlantic and collected on Barbados, consists almost entirely of particles less than $20 \mu \mathrm{m}$ and about half of this is comprised of particles with diameters less than $2 \mu \mathrm{m}$ (Prospero et al., 1970; Glaccum and Prospero, 1980). Physical processes of coarse particle reduction are not likely to produce mineral grains with diameters of $2 \mu \mathrm{m}$ or less. Furthermore, many (though not all) clay-sized particles have a very different mineralogy compared to that of coarse particles. Coarse particles, greater than $\sim 2 \mu \mathrm{m}$, consist largely of primary, rockforming minerals produced by igneous rock formation. Primary rock-forming minerals include quartz, plagioclase, K-feldspars, amphiboles, biotite, muscovite and a host of accessory minerals (in igneous rocks), as well as calcite and dolomite (in carbonate rocks). In contrast, many clay-sized particles are phyllosilicates, or layered aluminosilicate minerals, such as micas, kaolinite, smectite, vermiculite, and chlorite. Although micas (biotite and muscovite) are phyllosilicate minerals, they generally crystallize in rock-forming environments, through either igneous or metamorphic petrogenesis. In addition, some micas, such as illite, can form at low temperatures in the marine environment, through the alteration of volcanic ash that has been deposited in the ocean. However, kaolinite, smectite, vermiculite and many chlorites form at low temperatures at or near the Earth's surface, primarily in soils (Birkeland, 1999; Schaetzl and Anderson, 2005). The process is typically alteration of primary rock-forming minerals such as feldspars to phyllosilicate clay minerals by hydrolysis. Phyllosilicate clay minerals form a very important component of LRT dust (Glaccum and Prospero, 1980; Biscaye et al., 1997; Stuut et al., 2005) and identifying dust source areas requires a good understanding of how clay minerals form in soils and how clay mineralogy changes with soil geography.

Finally, a process that is often overlooked in studies of dust origins is particle inheritance from sedimentary rocks, such as siltstones or shales. In Australia, for example, siltstones may be the primary source of much of the silt-sized dust derived from arid basins (McTainsh, 1989). In the Great Plains of North America, Aleinikoff et al. (1999, 2008) show that sedimentary rock (volcaniclastic siltstone) is the most important source of silt-sized particles in loess of last-glacial age. Silt is abundant in the sedimentary rock record. Indeed, Blatt (1987) estimates that fully half 


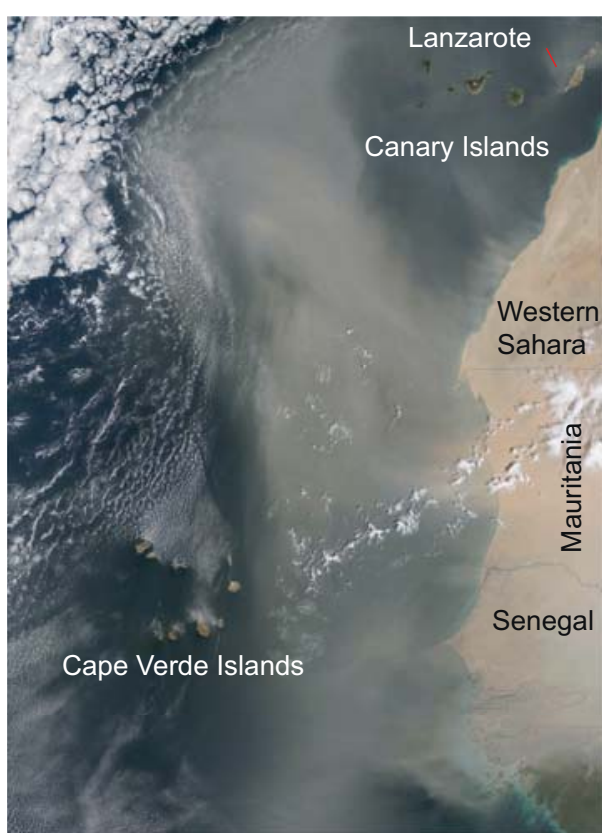

(a) 8 March 2006

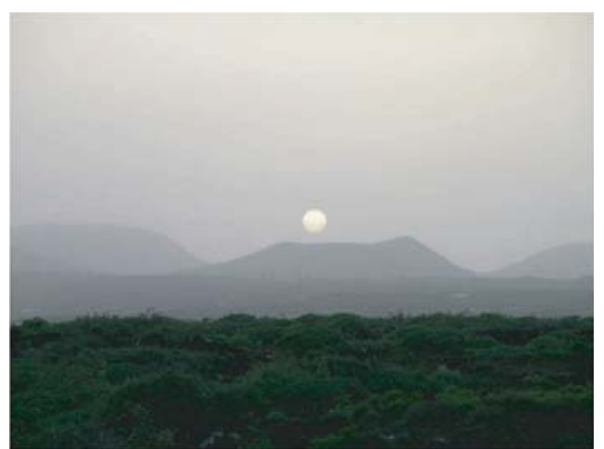

(b) 8 March 2006, Arrietta, Lanzarote

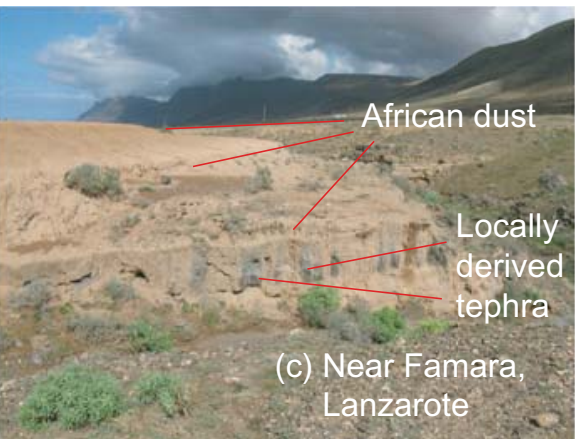

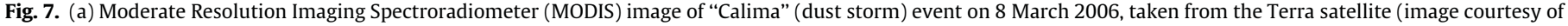

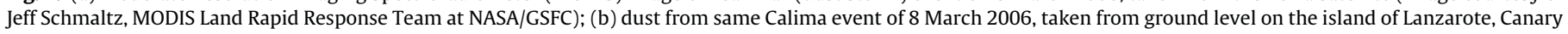
Islands; (c) mantle of long-term, African-derived dust on island of Lanzarote. Photographs in (b) and (c) by D.R. Muhs.

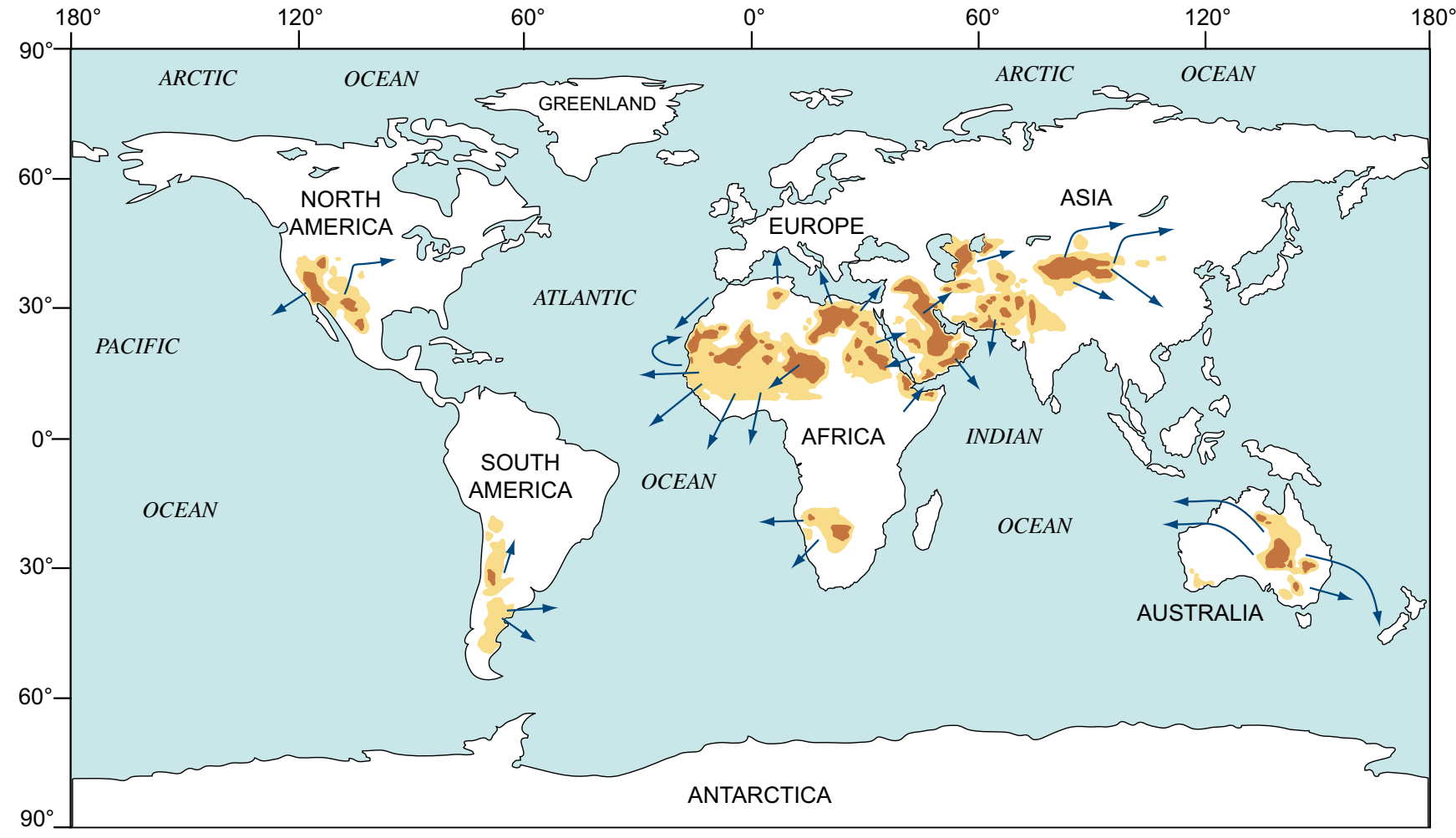

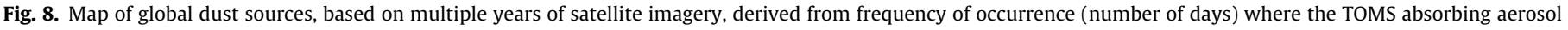

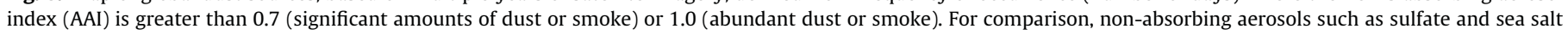

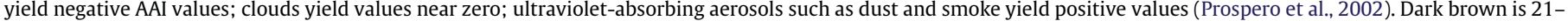

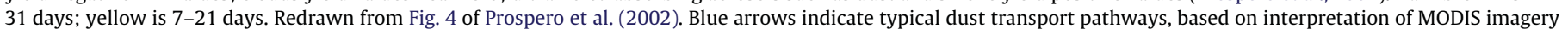
from Terra and Aqua satellites by D.R. Muhs. 


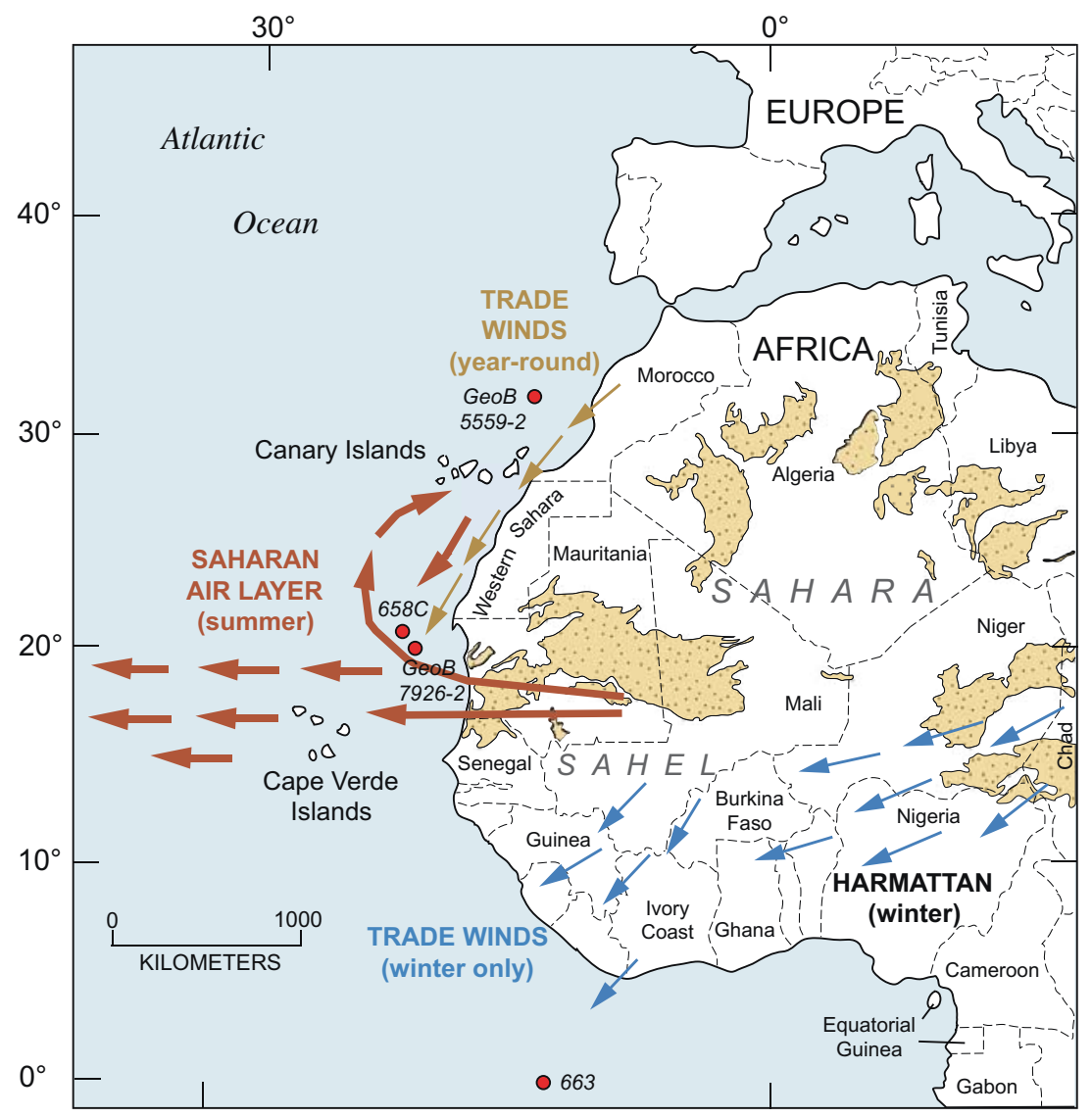

Fig. 9. Map showing northwestern Africa, localities referred to in the text, and the main dust-transporting winds and their seasons of transport. Dust-bearing wind paths generalized from Dubief (1979), Kalu (1979), Sarnthein et al. (1981), McTainsh and Walker (1982), Stein and Sarnthein (1984), Tetzlaff and Peters (1986), Pye (1987), Middleton and Goudie (2001), Stuut et al. (2005), and Schwanghart and Schütt (2008). Also shown (yellow stippled areas) are major active sand seas, generalized from "Global Soil Regions" map (http://www.soils.usda.gov/use/worldsoils/mapindex/order.html). Numbered red dots offshore are marine core locations where aeolian records are shown (Figs. 33-35).

of the detrital quartz in the world's sedimentary rocks is comprised of silt-sized particles.

\subsection{Dust source areas: the global picture}

The past couple of decades have added greatly to our identification of dust source areas, primarily through the use of Earth-orbiting satellites and a wide variety of sensors onboard these platforms. For example, as recently as a decade ago, there was little agreement about sources of dust in Africa, beyond the broad recognition of the importance of the Sahara and Sahel regions (Herrmann et al., 1999; Middleton and Goudie, 2001). In the past decade, analyses of satellite imagery, aerosol sampling networks, and back-trajectory calculations have allowed the sources of dust from Africa to be much better understood (Chiapello et al., 1997; Goudie and Middleton, 2001, 2006; Middleton and Goudie, 2001; Caquineau et al., 2002; Prospero et al., 2002; Washington et al., 2003). Direct observation of dust storms and dust source areas on a synoptic scale, within the visible spectrum, is now possible on a routine basis through MODIS and MISR imagery acquired from NASA's Terra and Aqua satellites. For example, a common occurrence is dust from the Sahara and Sahel regions of Africa transported to the eastern Atlantic Ocean off northwestern and western Africa (Fig. 7a). The scale of this imagery is such that it is possible to identify dust source areas, dominant pathways of dust transport (and their seasonal variability) and the areas over which dust is deposited. Following this, one can match these observations with short-term (Fig. 7b) and long-term (Fig. 7c) records of dust deposition on the ground.
A powerful tool for global dust source identification and transport pathways is also now available on a routine basis from other forms of satellite imagery. Aerosol indexes (AI) derived from the orbiting TOMS (total ozone mapping spectrometer) instrument have demonstrated that broad source areas for dust can be identified (Goudie and Middleton, 2001, 2006; Middleton and Goudie, 2001; Prospero et al., 2002; Washington et al., 2003). These studies have shown that the two most important dust source areas in the world at present are in the Sahara: the Bodéle depression in Chad and an area in the southwestern Sahara Desert region of Mali, Mauritania, and Algeria. The Bodéle Depression is estimated to be the largest single source of dust on the Earth at present based on TOMS data (Goudie and Middleton, 2001, 2006; Prospero et al., 2002; Washington et al., 2003). Recent field studies in the basin itself confirm the rapid rate of sediment removal by wind (Bristow et al., 2009).

Prospero et al. (2002) used TOMS imagery derived from several years to generate a global map of dust source areas. This map, combined with observations made from MODIS and MISR imagery, can give a global picture of dust sources and their dominant transport pathways (Fig. 8). Major dust source areas include the Sahara and Sahel regions of Africa, as noted above, but also the Arabian Peninsula, Central Asia, desert basins in China, central and southeastern Australia, the Mojave, Sonoran, and Chihuahuan deserts and Great Plains region of western North America, and the Pampas and Patagonian regions of southern South America. Prospero et al. (2002) point out that most dust source areas identified by interpretation of TOMS imagery are dominantly in topographic depressions and are usually remote from areas of human settlement. Thus, they 

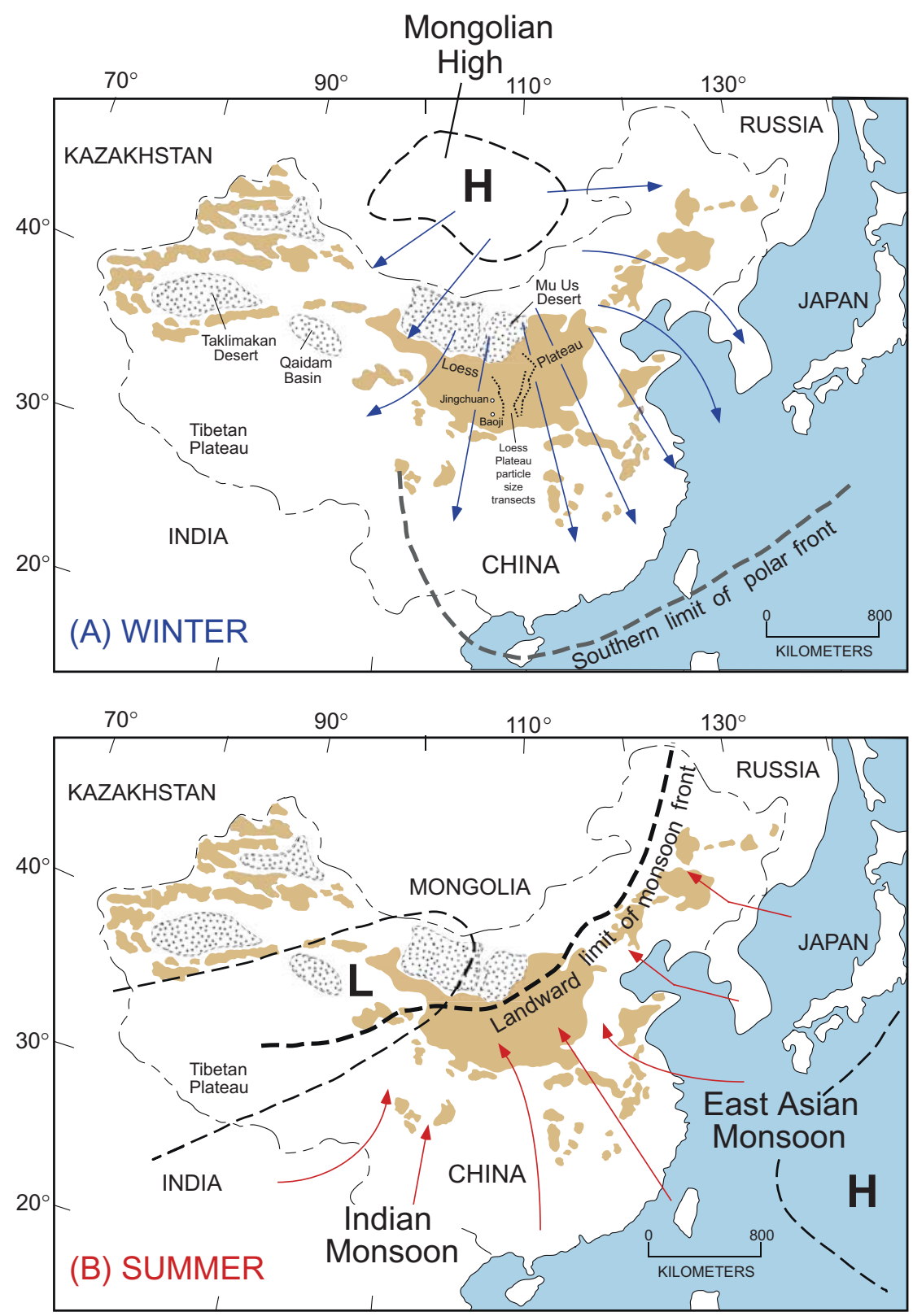

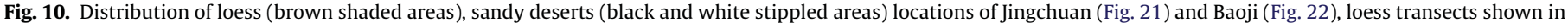

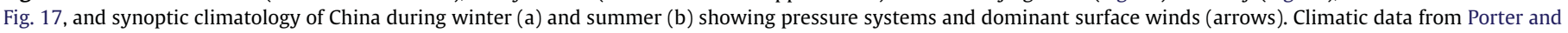
An (1995); loess distribution from Liu (1985).

conclude that most dust generation at present is due to natural processes, rather than anthropogenic causes, such as agriculture or urban development.

\subsection{Climatic controls on dust generation and transport from Africa}

With the wide variety of tools now available, it is possible to infer many of the details of specific dust sources areas using a combination of satellite imagery interpretation, back-trajectory analyses, geochemistry, and mineralogy. Dust generation in Africa and seasonal transport pathways from the continent are given here as an example (Fig. 9). It is important to note that this discussion refers to present-day pathways of dust transport and their climatic controls. In the geologic past, particularly during glacial periods, dust source areas changed in Africa and some dust transport pathways became more important than others. These climate changes give the geologic records of dust emissions from Africa a rich var- iability that is explored in detail in the individual sections on dust records.

One important contemporary dust pathway from Africa to the eastern Atlantic Ocean is powered by the northeasterly trade winds. These winds occur at relatively low altitudes $(0.5-1.5 \mathrm{~km})$ and can be dominant during any time of the year, although Stein and Sarnthein (1984) suggest that they transport dust only during winter and spring. According to Pye (1987), Sarnthein et al. (1981), Stein and Sarnthein (1984) and Stuut et al. (2005), the trade winds in this region entrain dust from the Atlas Mountains, the coastal region of Morocco, and parts of the northern Sahara. This dust is deposited along the African coast, onshore and offshore, in a zone extending from the Canary Islands to the Cape Verde Islands. Stein and Sarnthein (1984) suggest that the trade winds can also entrain "fallout" dust from the Saharan Air Layer, a second mode of transport discussed below. A number of investigators (Coudé-Gaussen et al., 1987; Bergametti et al., 1989; Grousset et al., 1992; Rognon 
et al., 1996) have emphasized the importance of relatively small, proximal areas in southern Morocco as sources for dust in the Canary Islands and adjacent parts of the eastern Atlantic Ocean via the trade winds.

A second pattern of wind transport is the dust-bearing Saharan Air Layer, or SAL, which occurs predominantly in boreal summer (Prospero et al., 1970; Carlson and Prospero, 1972; Prospero and Carlson, 1972; Prospero and Lamb, 2003). In boreal summer, the intertropical convergence zone (ITCZ) migrates north, and moist, tropical air from the south converges with dry, hot Saharan air from the north. With the convergence of these two contrasting air masses, the SAL is generated as dust is lifted by strong winds between about $15^{\circ} \mathrm{N}$ and $22^{\circ} \mathrm{N}$, associated with squall lines that occur at the ITCZ between $\sim 10^{\circ} \mathrm{N}$ and $15^{\circ} \mathrm{N}$ (see Fig. 4 in Tetzlaff and Peters, 1986). Near its sources in Africa, the SAL can reach altitudes as high as $5-7 \mathrm{~km}$, in the mid-troposphere and above the trade wind zone. At these higher altitudes, the winds are easterly and therefore dust is transported toward the Atlantic Ocean. By the time the SAL has reached the western Atlantic region, dust concentrations are greatest at altitudes of $1.5-3.7 \mathrm{~km}$, within the lower troposphere. Dust from the SAL can reach the island of Barbados in the Caribbean within about a week or less after departure from the western African coast (Prospero et al., 1970). In summer, dust from Africa is transported at least as far west and north as Florida (Prospero and Nees, 1987; Prospero, 1999) and very likely into the central and eastern United States (Perry et al., 1997; Kallos et al., 2006). Sarnthein et al. (1981), Stein and Sarnthein (1984), Tetzlaff and Peters (1986), and Pye (1987) point out that although the main direction of dust transport in the SAL is to the west at latitudes between $\sim 15^{\circ} \mathrm{N}$ and $\sim 21^{\circ} \mathrm{N}$, a south-to-north component of flow can occur in the lee of an easterly wave, and a "hook-like" trajectory of movement is observed (Fig. 9). This pattern of movement is shown on satellite imagery in Muhs et al. (2010) and was used to explain the origin of Sahel-derived dust to localities as far north as the Canary Islands.

A third pattern of dust transport from Africa to the Atlantic Ocean comes from the Harmattan winds. In contrast to the SAL, Harmattan winds occur during boreal winter, usually October to May (McTainsh, 1985), when the ITCZ migrates southward over southern Nigeria (Pye, 1987). Thus, these winds are essentially part of the boreal wintertime trade wind belt over Africa. Harmattan winds in winter are largely surface winds, with dust loads found at altitudes below $\sim 2 \mathrm{~km}$ (Dubief, 1979). Dust in Harmattan winds is carried southwestward over Niger and Burkina Faso, as well as over a broad zone of western Africa from Nigeria to Ghana (Fig. 9). Soils over a significant part of northern Nigeria are derived from Harmattan dust (McTainsh, 1984). When Harmattan winds reach the ITCZ in southern Nigeria, warm, moist, tropical air can undercut them, resulting in uplift of the dust-transporting air parcels (Kalu, 1979; Pye, 1987). As a consequence, LRT dust movement can take place westward within tropical latitudes. This phenomenon may explain wintertime dust deposition as far west and south as eastern South America (Prospero et al., 1981).

\subsection{Climatic controls on dust generation and transport from Asia}

Dust transport in Asia occurs mostly during the springtime transition between the seasonally alternating dominance of two principal air masses that reside over the eastern part of the continent (Porter and An, 1995). During the winter, the region is dominated by the Mongolian high-pressure system, which delivers cold, dry air to China with northerly winds (Fig. 10). Northerly winds are the driving force behind dust entrainment and transport to the Chinese Loess Plateau, but dust storms at present are most frequent at the end of the winter, in April (Sun et al., 2001). In summer, low pressure develops over the Asian continental interior and higher pressure over the western Pacific Ocean generates the East Asian Monsoon, with a landward flow of warm, humid air to China under gentle winds (Fig. 10). Little or no dust entrainment occurs under these conditions of humid air, weak winds and abundant precipitation. As will be shown later, it is thought that during glacial periods, the residence time of the present wintertime regime was longer and the residence time of the summertime regime shorter than is the case today. As a result, the flux of dust was greater during glacial periods and is reflected in the geologic records of loess deposits and lake sediments in Asia and marine sediments of the Pacific Ocean.

\subsection{Climatic controls on dust generation and transport from Australia, South America and North America}

Dust generation in Australia has been reviewed extensively by Hesse and McTainsh (2003) and is summarized here. As is apparent from TOMS imagery (Fig. 8), there are two major dust pathways, both originating in basins in the east-central part of the continent. These dust source areas are primarily the Lake Eyre basin and the western part of the Murray-Darling Basin. Both transport pathways are associated with frontal systems, the southeast dust plume with those in the zonal westerly system and the northwest dust plume with those in the trade wind zone. Of the two dust paths, the southeast one is the most important, but both were intensified during the last glacial period. Hesse and McTainsh (2003) infer that the more dramatic dust flux along the southeastern path during the last glacial period was likely due not to stronger winds but to a weaker hydrological cycle. Geologic records of dust from the northwest plume are found in marine cores of the Indian Ocean, whereas records of dust from the southeast plume are found in cores taken from the Tasman Sea and the southwest Pacific Ocean, as well as on New Zealand.

The main dust source areas in South America at the present time are Patagonia, central-western Argentina, and the Puna-Altiplano plateau, based on interpretation of TOMS imagery (Fig. 8) by Prospero et al. (2002). Of these three areas, Patagonia is thought to be the most important source. Pacific-derived air masses lose moisture on the western side of the Andes so upon arrival in Patagonia, on the eastern side of the mountains, they are relatively dry. Gaiero et al. (2003) point out that the dry, westerly winds in this region sweep over broad glacial outwash plains to the east of the Andes. During the maximum extent of glacial ice from the Andes during the last glacial period, there was a greater delivery of source sediments to these outwash plains (Sugden et al., 2009).

In North America, TOMS imagery indicates that the main sources of dust at present are in the desert basins of the southwestern US and northwestern Mexico, with some additional sources in other parts of the Basin and Range province and the southern Great Plains (Fig. 8). In the Mojave and Amargosa Deserts of the southwestern U.S., two of the major dust-producing regions, Reheis (2006), Reheis and Kihl (1995) and Reheis et al. (2002, 2009) identify four main dust-generating sources in these basins: (1) alluvial sediments; (2) playas; (3) the human-induced dry playa of Owens Lake; and (4) local anthropogenic and/or volcanic emissions. Thus, this region is an exception to the general global observation of Prospero et al. (2002) that the majority of dust source areas at present are not due to anthropogenic disturbances. Winds that entrain dust in the southwestern US and northwestern Mexico at present are dominantly from the west, but under Santa Ana conditions that develop in fall, winter and spring, dust-generating winds are easterly (Muhs et al., 2007b, 2008c). In the southern Great Plains region, Gillette and Hanson (1989) show that the time of maximum dust production is in the spring, with summer being the time of minimum dust production. During the last glacial period, the main locus of dust generation was in the central part of North America, in the Great 

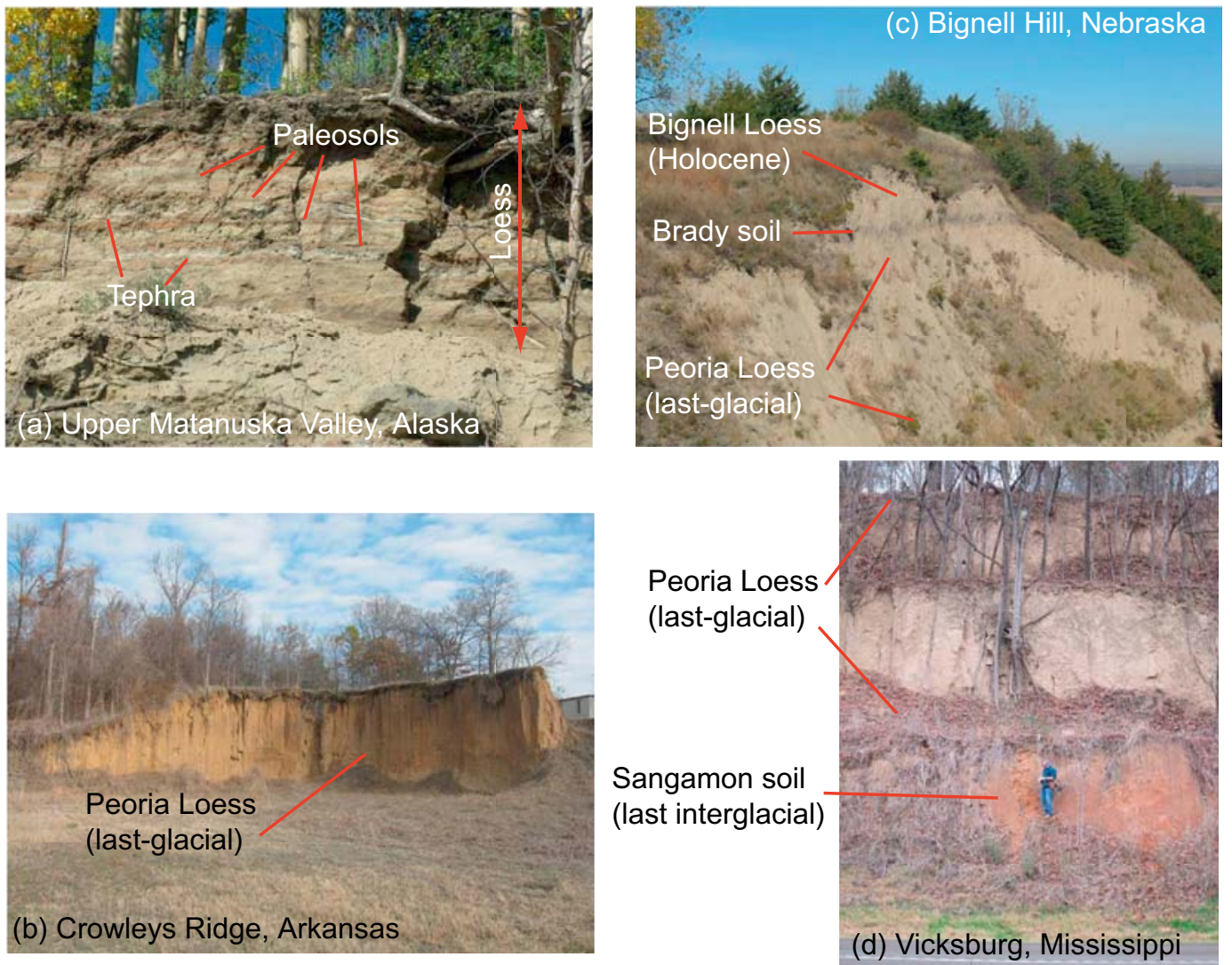

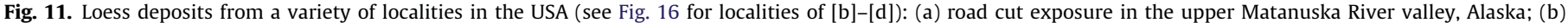
Crowleys Ridge, Arkansas; (c) Bignell Hill, Nebraska; (d) Vicksburg, Mississippi. Photographs by D.R. Muhs (a,b, and c) and John Aleinikoff (d).

Plains and greater Mississippi River basin, to the southwest and south of the Laurentide ice sheet (see reconstructions by Mahowald et al., 2006). Both glacial and non-glacial sources generated dust and winds were dominantly from the west, as they are today (Muhs and Bettis, 2000; Muhs et al., 2008a).

\section{Geologic records of dust}

In this review, five types of geologic records of dust are summarized. By "geologic records," the implication is that these are records of dust deposition that are of longer duration than those possible via monitoring within the historic period of human observation. Emphasis is placed on the role that such records play in inferring paleoclimate. Each type of dust record, like all geologic records, has its own particular advantages and disadvantages with regard to inference about paleoclimate. Dust can be deposited as marine sediment of the deep-ocean floor, in lakes, as loess deposits, in polar ice sheets, and in soils on the continents. Viewed in this context, the array of geologic archives shows that dust in some form can reach and be retained in almost all parts of the Earth's surface, whether on land or in the ocean. In reviewing these various records, I start with where dust is generated, on the continents, and examine the dust records in loess, lakes, and soils. Following that, I review dust records where the particles have traveled farther from the continents, to the oceans and polar ice sheets.

\section{Loess deposits}

Loess is aeolian sediment dominated by silt-sized particles. As such, it can be considered to be a geologic record of dust, although, as emphasized earlier, much loess has been transported relatively short distances (less than $\sim 100 \mathrm{~km}$ ) as opposed to LRT dust. It is one of the most extensive deposits on the land surface of the Earth and soils developed in it form some of the most productive agricultural land in the world. Loess is also one of the most important archives of Quaternary climate change. Combined with intercalated paleosols (buried soils), loess provides one of the most complete terrestrial records of interglacial-glacial cycles. Thus, given favorable circumstances, loess can be used to reconstruct synoptic-scale paleoclimatology over millennial timescales. In addition, fossil organisms or their remnants (gastropod shells, mammal remains, pollen and organic matter) also provide valuable paleoclimatic information. One distinct advantage of loess compared to other Quaternary sediments (such as till, alluvium or colluvium) is that it can be dated directly, using luminescence methods. Roberts (2008), Singhvi and Porat (2008) and Wintle (2008) review some of the most recent advances in luminescence dating as they apply to loess deposits. Loess deposits are also commonly the host sediments for the shells of minute gastropods (land snails), and have been used extensively for paleoclimatic interpretations in North America, Europe and China. Radiocarbon dating of mollusks has had a controversial history, but new studies by Pigati et al. (2010) have shown that certain genera of land snails do not incorporate significant amounts of "dead" carbon from calcareous substrates. These same genera are common in loess and yield radiocarbon ages that are in good agreement with radiocarbon ages of stratigraphically equivalent plant macrofossils.

Loess can be recognized in the field as a distinctive sedimentary body (Fig. 11). Its thickness is highly variable and can range from a few centimeters to several hundred meters. Variability of loess thickness is, in fact, one of its advantages as a paleoclimate 
indicator, as spatial trends in loess thickness provide information about paleowind directions. Loess deposits are commonly draped over pre-existing landforms as a mantle, with thickest accumulations in protected, low-lying areas or broad, flat, stable upland divides, close to source areas. Thinnest accumulations occur on narrow, rounded hillcrests and/or locations distant from source areas. Unlike aeolian sands, fluvial sediments, or marine sediments, primary structures in loess are subtle or, more frequently, absent altogether. Faint, horizontal laminations and, less commonly, cross-bedding are sometimes apparent in loess deposits, but are the exception rather than the rule. Nevertheless, interparticle binding by phyllosilicate clay minerals or secondary calcite accumulation often results in a significant amount of material strength in loess. This sediment strength explains the ability of loess deposits to form vertical faces along river or stream banks and road cuts (Fig. 11). While primary structures in loess are generally lacking, secondary structures are common, and consist of fractures, burrows, rhizoliths (root casts composed of Fe-oxides or carbonate), carbonate nodules or concretions, oxidation or reduction streaks or bands, and paleosols. Loess typically has a mineralogy that includes quartz, plagioclase, K-feldspar, mica, calcite (sometimes with dolomite), and phyllosilicate clay minerals (smectite, chlorite, mica, and kaolinite). Heavy minerals are usually present, but in small amounts.

\subsection{Geography of loess}

Some of the most extensive tracts of loess in the world are found in Asia. The largest contiguous area, and that which has received the most study, is the Loess Plateau in the central part of the China (Fig. 10). In the northwestern part of the Loess Plateau, near Lanzhou, loess deposition has been ongoing for more than a million years and, in fact, the accumulation of loess in this area may be the thickest occurrence on Earth. Smaller but still significant areas of loess are found to the northeast of the Loess Plateau between Mongolia and North Korea. Loess is also found around the rim of the Tarim Basin (Taklimakan Desert) in western China and in extreme northwestern China, to the north of the Tarim Basin, between Mongolia and Kazakhstan. Loess in Central Asia is found primarily in Tajikistan, Kyrgyzstan, Turkmenistan, Uzbekistan and Kazakhstan (Fig. 12). Loess occurs in a number of regions within Siberia, although the spatial extent of some loess bodies is better known than others and there is still debate about whether some silt-rich deposits in parts of Siberia are truly aeolian or not (Péwé and Journaux, 1983; Schirrmeister et al., 2011). Loess in northern Kazakhstan extends into a larger area of loess in the southern part of western Siberia.

In Europe, loess is found over a broad area from France to Russia (Fig. 13). It has not been found in significant amounts north of the southern extent of the Fennoscandian ice sheet, nor has it been reported in thick accumulations in southern Europe. Thus, except for Iceland, discussed earlier, loess is absent from the Scandinavian countries and in most countries bordering the Mediterranean. Much loess in western and central Europe is found bordering major river systems, such as the Danube and the Rhine, which carried silt-sized particles derived from the Alps or Carpathian Mountains. Farther north, and particularly farther northeast in Russia, many large loess bodies are also situated adjacent to major river systems (Dnepr, Don and Volga rivers) and this sediment ultimately may have been derived from glacial deposits of the Fennoscandian ice sheet (Smalley et al., 2009). Frechen et al. (2003), Rousseau et al. (2007) and Haase et al. (2007) review the origins, distribution and and ages of loess in Europe.

In contrast to Eurasia, loess is not extensive in either Africa or adjacent parts of the Middle East. Given the identification of Africa as the most important source of dust at present (Fig. 8), this comes

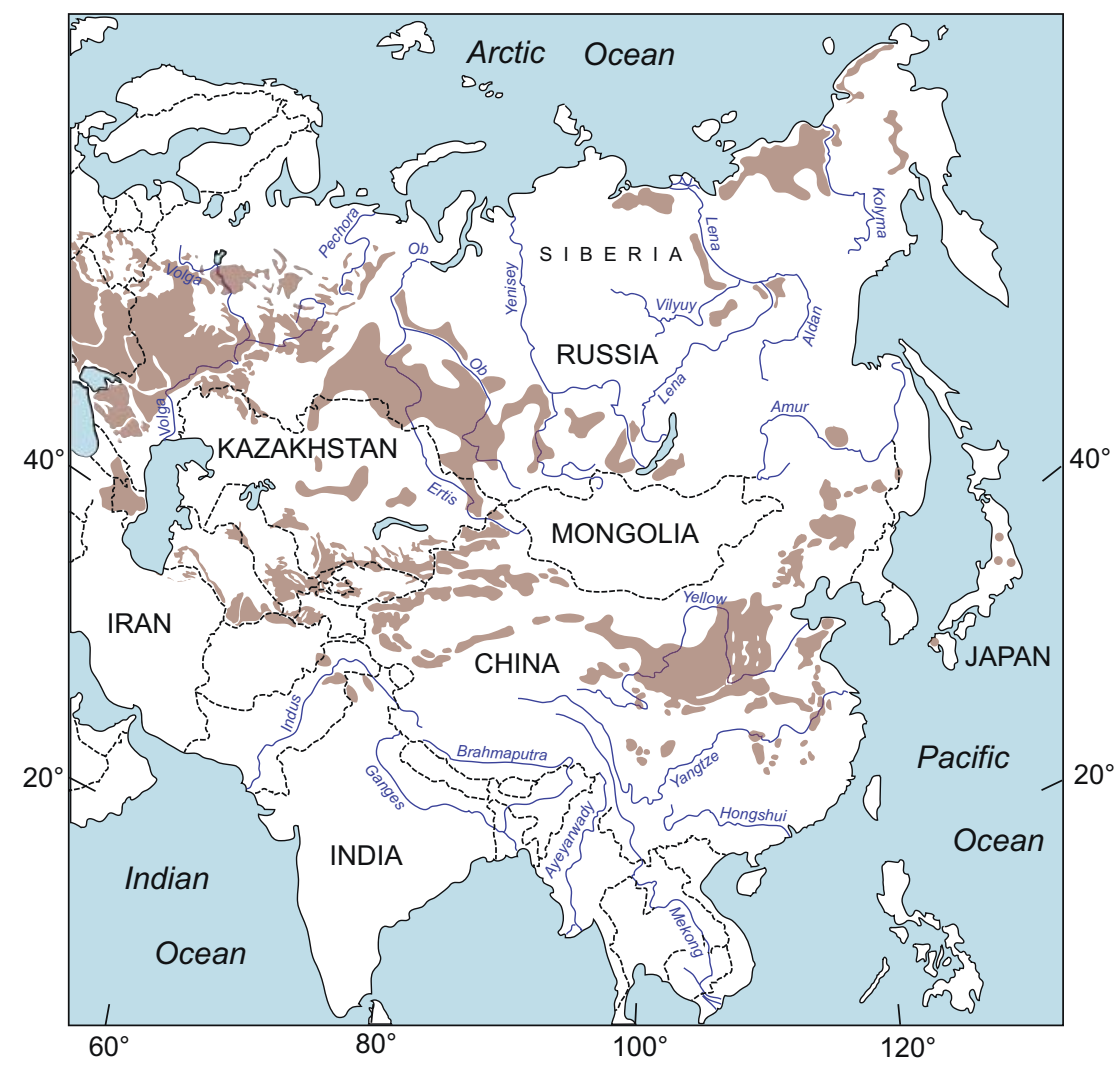

Fig. 12. Distribution of loess in Asia, compiled from Velichko et al. (1984, 2006), Liu (1985), Dodonov (2007) and Frechen et al. (2009). 


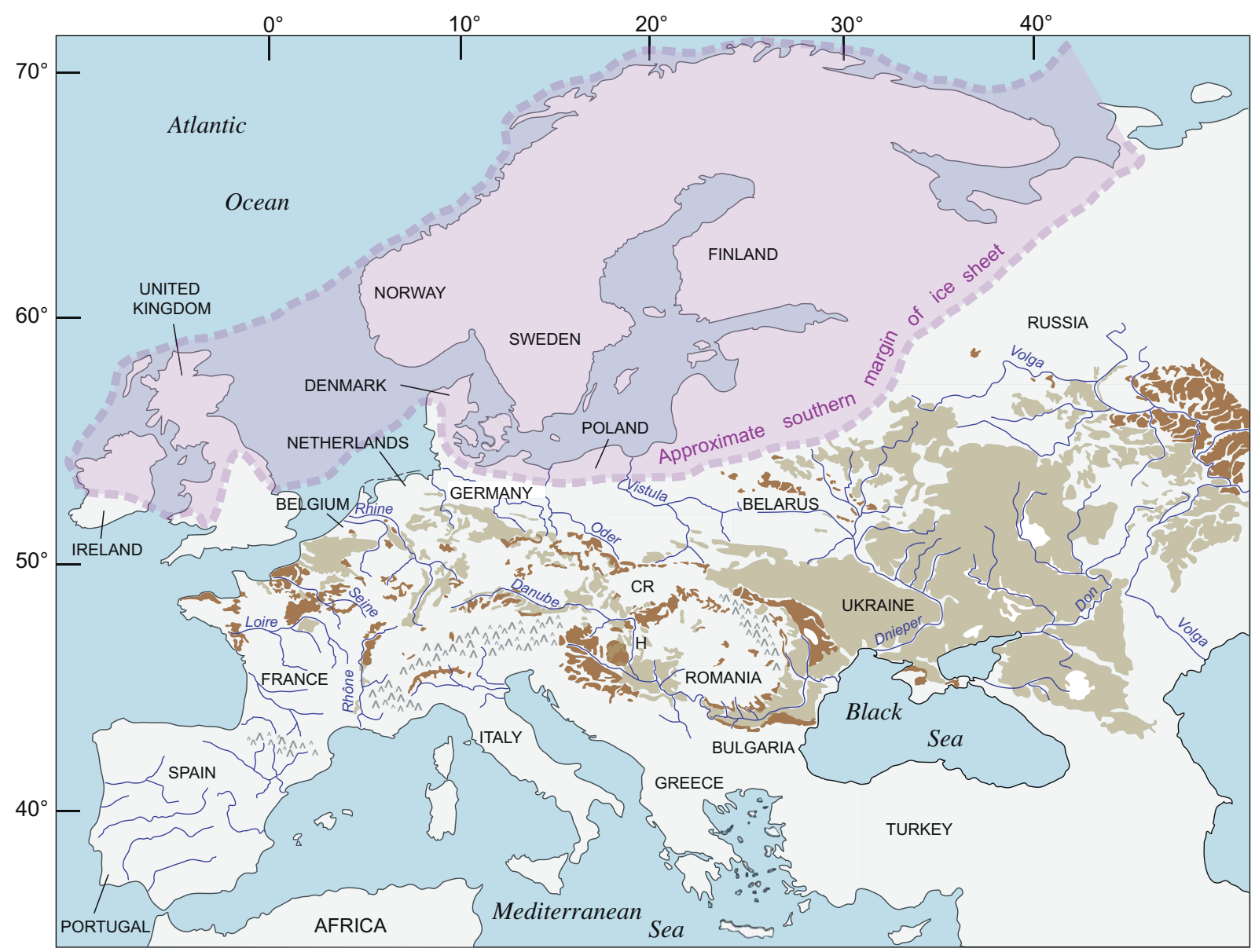

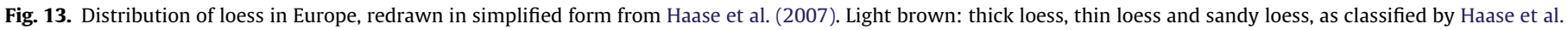

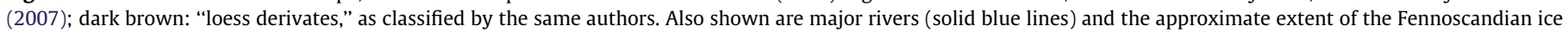
sheet during the last glacial period (light purple shade), simplified from Flint (1971). CR, Czech Republic; H, Hungary.

as something of a surprise, although Tsoar and Pye (1987) point out that arid regions rarely have the necessary conditions for trapping loess. Nevertheless, small and widely separated occurrences of loess or loess-like deposits are documented in parts of North Africa, the Middle East and the Arabian Peninsula, based on a recent compilation by Crouvi et al. (2010). Loess-like deposits have also been described on the Canary Islands, off the northwestern coast of Africa (Von Suchodoletz et al., 2009; Muhs et al., 2010) and the Cape Verde Islands (Rognon et al., 1996). Loess in Israel has received the most attention of any in this region, beginning with pioneering studies by Dan and Yaalon (1971). Dust is transported to Israel in part from desert areas to the west in Sinai and possibly the Sahara (Dan and Yaalon, 1971) and in part from dune fields nearby (Crouvi et al., 2008). A long-term record of loess can be found in parts of western Israel (Fig. 14). Optically stimulated luminescence ages indicate that the Israeli loess record here goes back at least to the penultimate glacial period and perhaps older (Wieder et al., 2008; Crouvi et al., 2008).

Loess is extensive in North America, south of the area that was occupied by the Laurentide and Cordilleran ice sheets (Fig. 15a). Significant areas of loess are found in the Palouse area of eastern Washington and adjacent Oregon and the Snake River Plain and adjacent uplands of Idaho. Loess is also found discontinuously in Alaska (USA) and the adjacent western part of Yukon Territory (Canada). Most of Canada has little loess, however, because the region was covered by the Laurentide and Cordilleran ice sheets during the last and previous glaciations (Fig. 15a). Even after deglaciation, little loess accumulated in Canada, because silt-sized particles carried by outwash were deposited in large proglacial lakes (Flint, 1971). Vegetation colonized most of the former lake surfaces shortly after lake drainage and thus there was little opportunity for aeolian entrainment of silt. However, south of the Laurentide ice sheet, there was extensive loess deposition during the last and previous glaciations. By far the greatest extent of loess (and that with the greatest thickness) in North America is in the Great Plains region east of the Rocky Mountains and extending into the greater Mississippi River drainage basin, from Colorado to Ohio. As in Europe, loess bodies of the North American mid-continent appear to be continuous when viewed broadly. On a finer scale, however, it is apparent that individual loess bodies have very different thickness trends that are not part of a larger regional trend (Fig. 16).

Although less extensive than in the Northern Hemisphere, loess is also found in the Southern Hemisphere. In South America, loess is found in the southern part of the continent, especially in Argentina (Fig. 15b). In this country, there are two major loess belts, informally referred to as the Pampas loess in central Argentina and the Chaco loess in northern Argentina (Zárate, 2003, 2007). Smaller areas of loess may be present in southern Bolivia and loess is tentatively mapped in the western and southern parts of Uruguay, although more detailed study is necessary to confirm this.

Loess, as it is described on other continents, is largely absent in Australia, although there are deposits of "parna," a clay-rich sediment that may have been transported as silt-sized aggregates of clay (Butler, 1956, 1974). Butler (1956) considered parna to be distinct from what has classically been considered to be loess on other 
(a)

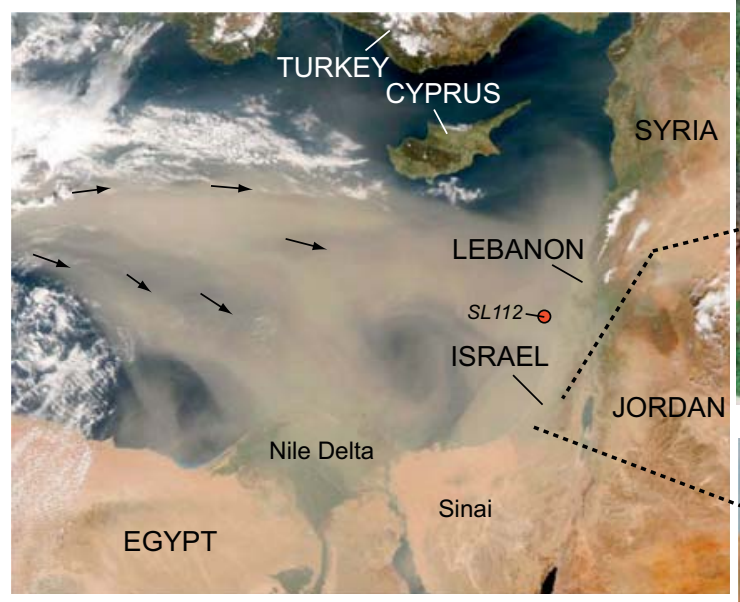

24 February 2007, MODIS, Aqua satellite

(b)
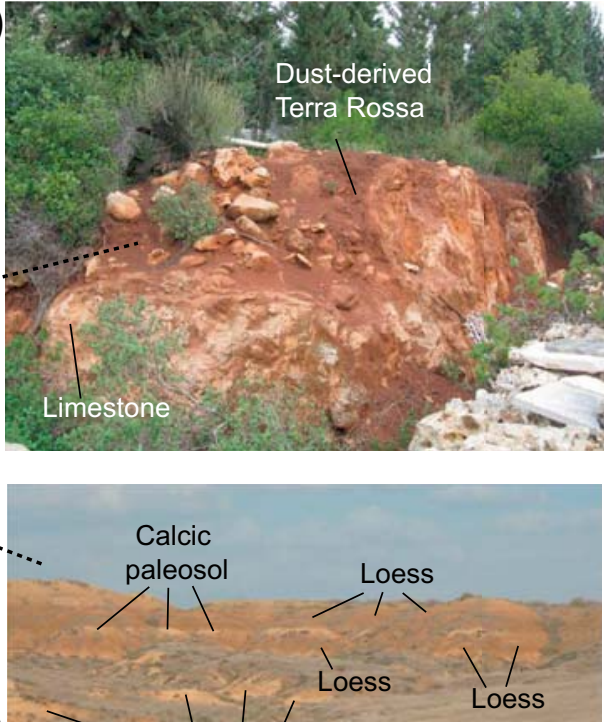

(c)

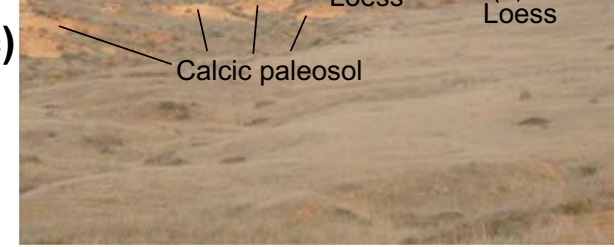

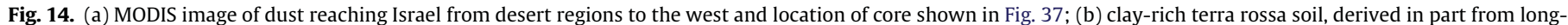

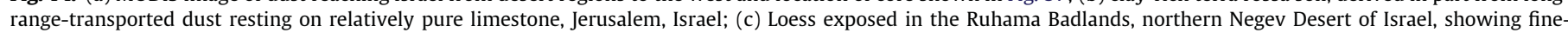

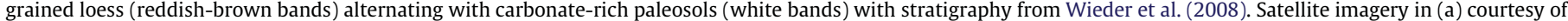
the MODIS Rapid Response Team, NASA Goddard Space Flight Center; photographs in (b) and (c) by D.R. Muhs.

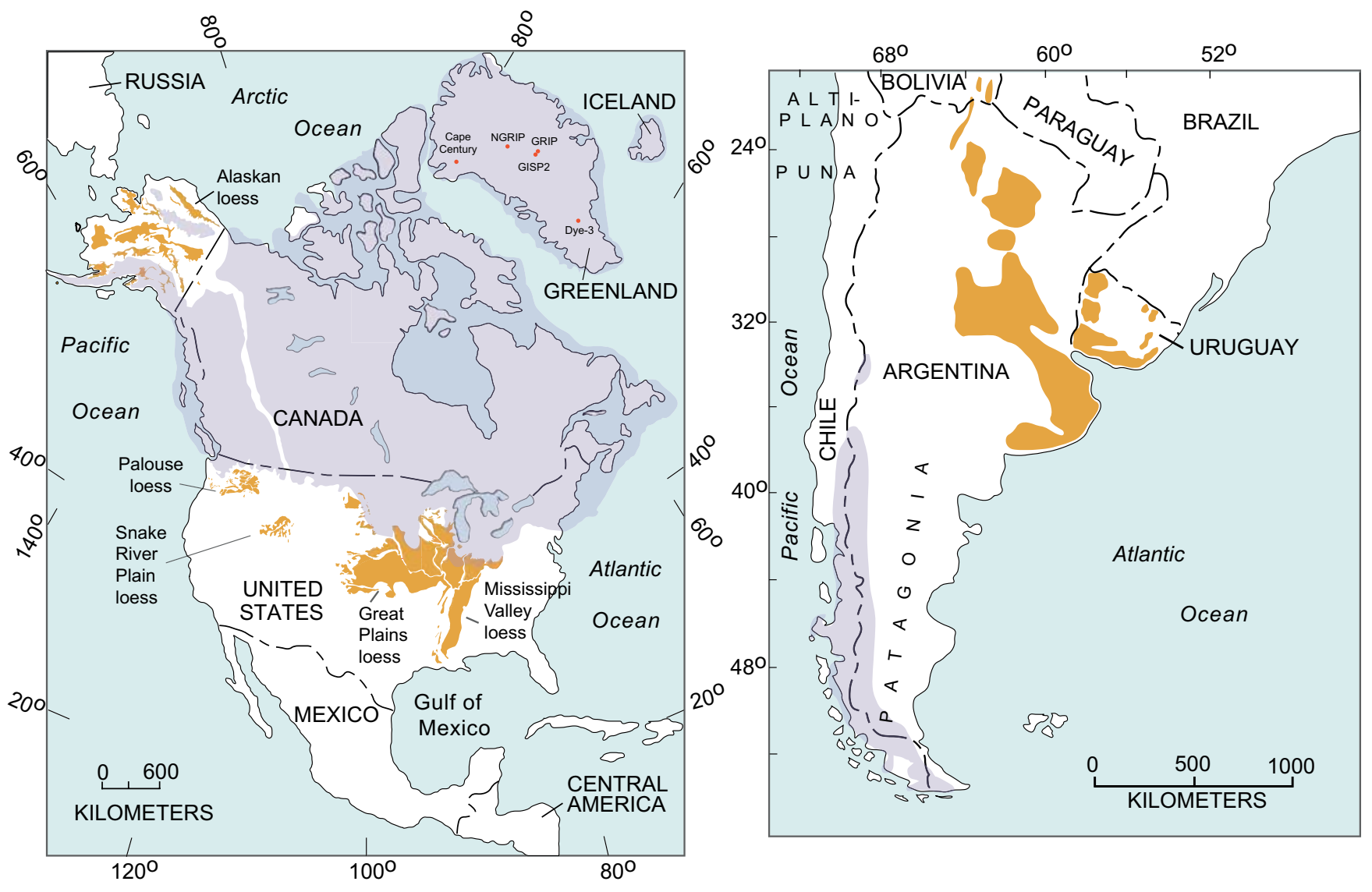

Fig. 15. Distribution of loess in the Americas. (a) North America, compiled from Péwé (1975), Bettis et al. (2003), Muhs et al. (2003a), Busacca et al. (2004) and sources

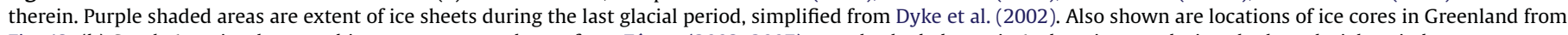
Fig. 43. (b) South America, loess and ice cap extents redrawn from Zárate (2003, 2007); purple shaded area is Andean ice cap during the last glacial period. 


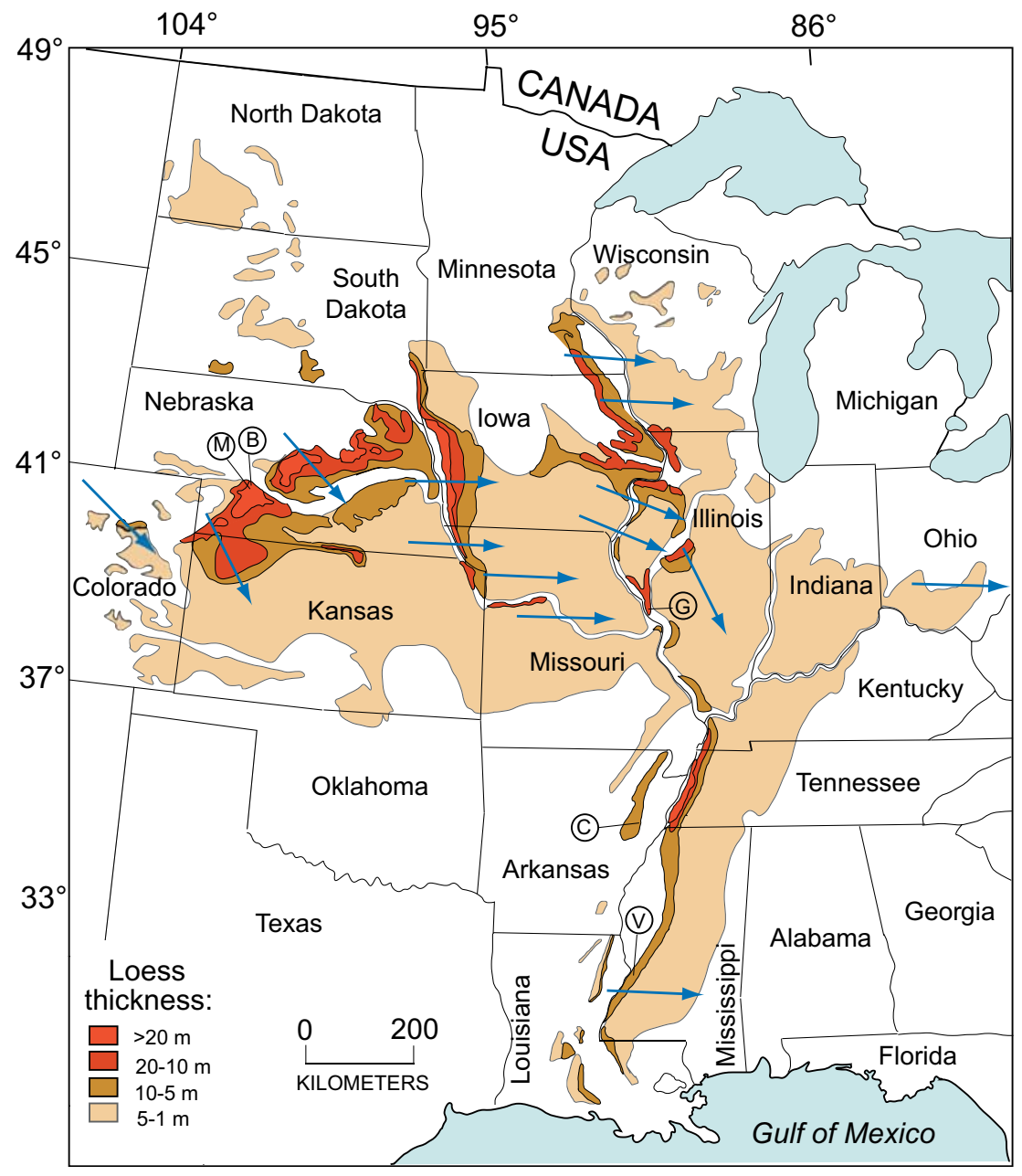

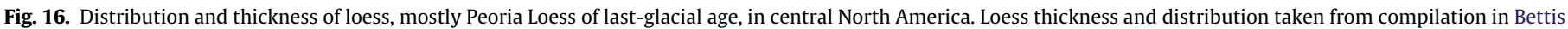

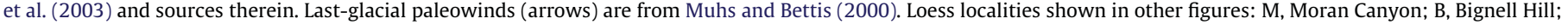
G; Greenbay Hollow; C, Crowleys Ridge; V; Vicksburg.

continents. Cattle et al. (2009) point out, however, that modern definitions of clayey loess could certainly include Butler's original definition of parna. Cattle et al. (2009) and Greene et al. (2009) show that in the classic parna region of Australia, there are significant areas of loessic soils, where an aeolian mantle comprises the upper part of the profile. There is also considerable evidence of exotic quartz in Australian soils (Hesse and McTainsh, 2003). To the southeast of Australia, loess is found over much of New Zealand, where its stratigraphy (e.g., Berryman, 1993; Graham et al., 2001) and distribution have been studied in considerable detail. Eden and Hammond (2003) show that the largest areas of loess, dominated by quartz and feldspar, are found on the South Island of New Zealand, whereas smaller areas of "volcanic" loess are found on the North Island.

\subsection{Sedimentology of loess}

Loess has a distinctive particle size distribution, with mean particle sizes finer than aeolian sand, but coarser than aerosolic, LRT dust. Whereas dune sand is characterized by mean particle sizes in the medium-to-fine sand range and aerosolic dust is fine silt and clay, loess is dominated by coarse-to-fine silts. Mean particle sizes of loess range from coarse $(63-31 \mu \mathrm{m})$ to fine $(16-8 \mu \mathrm{m})$ silt. The wide range of mean particle size and relatively poor sorting can be the result of (a) multiple sources, (b) clay-sized particles being transported as silt-sized aggregates, (c) loess bodies extending considerable distances from their sources, and/or (d) varying wind strengths over time.

A number of studies have shown that mean particle size of loess is at least partly a function of distance from the source, where there is a systematic winnowing of coarse particles in the downwind direction. In China, for example, loess in the northern part of the Loess Plateau has a median particle size of about $80 \mu \mathrm{m}$ (Porter et al., 2001). At the southern portion of this loess body, $\sim 300 \mathrm{~km}$ to the southeast, loess has a median particle size of about $20 \mu \mathrm{m}$. As will be shown later, this is considerably coarser than LRT dust (also derived from desert basins in China) that is deposited in Lake Biwa, Japan and the western Pacific Ocean. Distance plots by Ding et al. (2005) show that the sand fraction $(>63 \mu \mathrm{m})$ in the Chinese Loess Plateau drops off dramatically as one moves downwind from desert source regions, such as the Mu Us Desert, both for L-1-1 loess that dates to the last glacial maximum (LGM, or marine isotope stage [MIS] 2) and loess L-1-5 that dates to the early last glacial period (MIS 4), as shown in Fig. 17. In the state of Nebraska USA, loess is extensive and is for the most part unrelated to glacial sources (Fig. 18). Studies by Aleinikoff et al. (2008) and Muhs et al. (2008a) show that the most likely source of loess is Tertiary siltstone of the White River Group that crops out in northwestern Nebraska and adjacent states (such as Badlands National Park shown in Fig. 18). Mason (2001) suggests that from this source area, fine- 

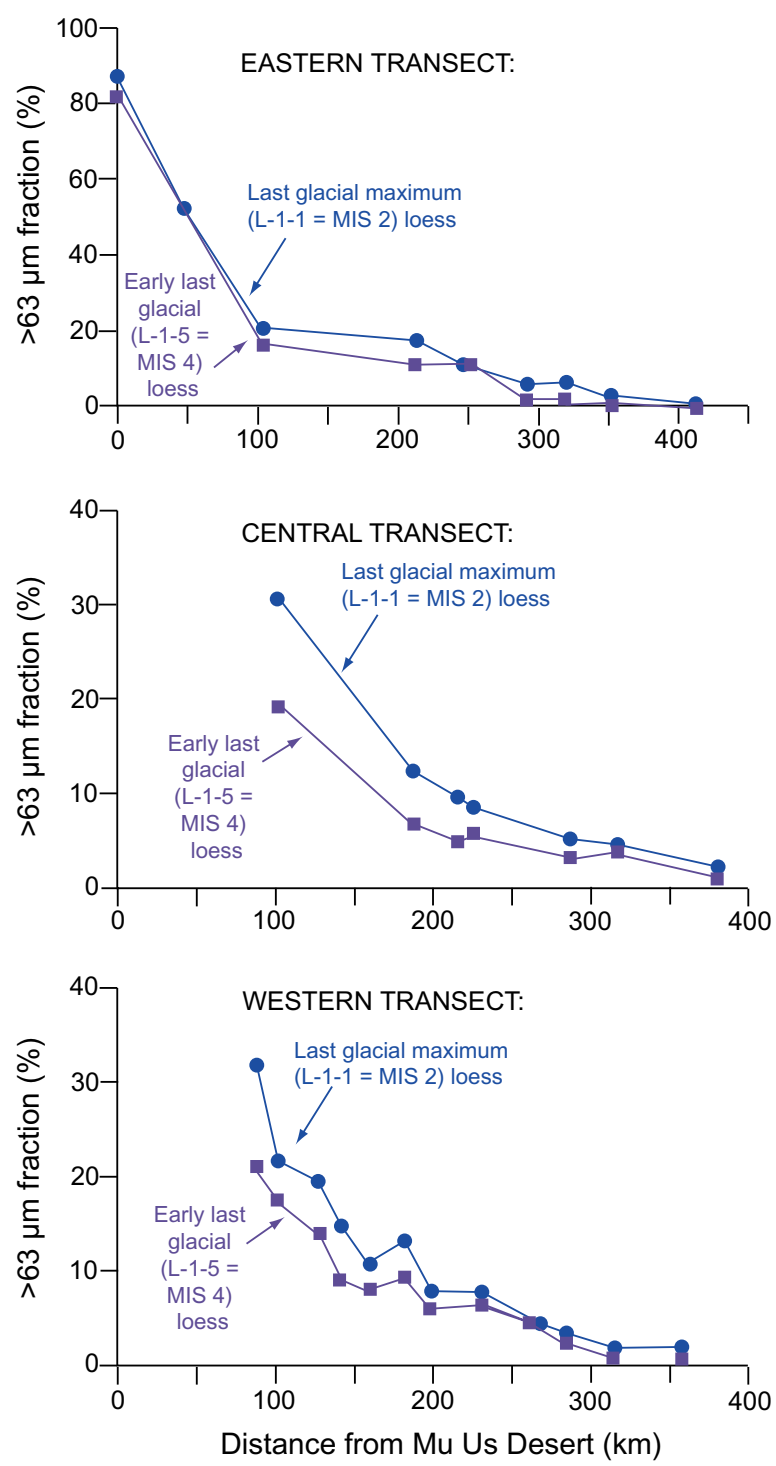

Fig. 17. Transects across the Loess Plateau in China (see Fig. 10 for location of transects), showing change in particle size with distance downwind from the Mu Us Desert, one of the immediate sources of loess. Redrawn in simplified form from Ding et al. (2005).

grained particles were probably transported by suspension over (and kept in suspension by) an active dune field, the Nebraska Sand Hills (Mason et al., 2011). Although this dune field played a crucial role in transporting fine-grained particles southeastward over long distances, it apparently contributed very little to the loess that was eventually deposited. By the time one has reached a distance a few tens of $\mathrm{km}$ southeast of the dune field, the loess is more than $90 \%$ silt $(53-2 \mu \mathrm{m})$ and clay particles $(<2 \mu \mathrm{m})$.

\subsection{Loess stratigraphy in mid-continental North America}

In those parts of North America where loess is derived dominantly from glacial sources (Fig. 1), loess stratigraphy provides, at a first approximation, a straightforward record of glacial-interglacial cycles. In this simplified view, glacial periods are mostly periods of loess deposition whereas interglacial periods are mostly periods of soil formation (see Bettis et al., 2003; Busacca et al., 2004; Muhs, 2007; and Roberts et al., 2007 for reviews). In the mid-continent region of North America, for example, loess sections adjacent to the Mississippi River valley illustrate this relation. The three youngest loess units are the Loveland Loess of penultimate glacial age, the Roxana Silt (loess) of early-last-glacial age and Peoria Loess of late-last-glacial age (Fig. 19). Loveland Loess is typically no more than a few meters thick and is sometimes absent. A prominent paleosol developed in the upper part of the Loveland Loess is referred to as the Sangamon Geosol or simply the Sangamon soil (informal term), which formed during the last interglacial period. The Sangamon Geosol is usually very well expressed morphologically, with a thick, reddish-brown, clay-rich profile. Roxana Silt (loess) was deposited after the last interglacial period, probably during the early part of the last glacial period. It is usually quite thin, commonly only a meter or less thick, except in the lower Mississippi River valley, where it can be several meters thick. A dark, organic-rich paleosol called the Farmdale Geosol (informally called the Farmdale soil) developed in the upper part of the Roxana Silt. The Farmdale Geosol is overlain by Peoria Loess, which dates to the last glacial period, about 25,000-12,000 radiocarbon years ago ( $\sim 30,000$ to $\sim 14,000$ calendar years ago), based on dating conducted at many sections (Bettis et al., 2003). Loveland Loess can be correlated with the penultimate glacial period (MIS 6), the Sangamon soil probably developed during all of MIS 5 and perhaps part of MIS 4, Roxana Silt was probably deposited during MIS 4 or 3, the Farmdale soil formed during MIS 3, Peoria Loess was deposited during the last glacial period (MIS 2), and the modern soil has been developing since the current interglacial (MIS 1, or the Holocene) began. Where sedimentation rates are moderate, it is common to see the reddish-brown Sangamon Geosol, the grayish-brown Roxana Silt, the dark-brown Farmdale Geosol and the light yellowish-brown Peoria Loess in a complete vertical sequence in one exposure (Fig. 11d).

The nature of the loess/paleosol sequences in mid-continental North America and correlation to the deep-sea oxygen isotope record are illustrated by an example from near the Mississippi River, at a locality called Greenbay Hollow (Fig. 19). Loess in this region is originally rich in carbonates, both calcite and dolomite, derived from Paleozoic limestones and dolostones that were traversed by the Laurentide ice sheet during both the penultimate glacial period and the last glacial period. During periods of non-deposition of loess, soils form. During pedogenesis, carbonates are leached, as seen in the $\mathrm{CaO} / \mathrm{TiO}_{2}$ and $\mathrm{MgO} / \mathrm{TiO}_{2}$ profiles at Greenbay Hollow, where low values are found in the Sangamon soil, Farmdale soil, and modern soil. During these periods, clay enrichment in soil B horizons also takes place, as reflected in the $\mathrm{Al}_{2} \mathrm{O}_{3}$ content profile at Greenbay Hollow.

West of the Missouri River in the Great Plains region of Nebraska, Kansas, and Colorado (Fig. 16), loess is not glaciogenic, but, as discussed above, is derived from volcaniclastic siltstone of Tertiary age. Thus, with a non-glacial source of loess in this region, one should not necessarily expect that loess deposition is a "turn-on/ turn-off" phenomenon that is tightly linked to glacial periods. Both radiocarbon and OSL ages of the uppermost loess unit in the Great Plains, called the Bignell Loess, have confirmed that Holocene loess is widespread in the region (Mason et al., 2003; Miao et al., 2005, 2007; Muhs et al., 2008a). In fact, Holocene loess deposition in the region was episodic, as shown by the presence of paleosols (Fig. 20). Miao et al. $(2005,2007)$ have shown that the timing of Holocene loess deposition is similar to the timing of eolian sand deposition in the Nebraska Sand Hills (Fig. 18), in support of the model presented by Mason (2001). This indicates that the Nebraska Sand Hills played an important role in fine-particle transport as well as coarse-particle transport while it was active. In addition, these findings suggest similar climatic controls on sand dune activity and loess transport. Miao et al. $(2005,2007)$ conclude that regional drought is the most likely climatic control on both dune activity and loess transport in the central Great Plains during the Holocene. Thicker glacial-age loess is also present. 


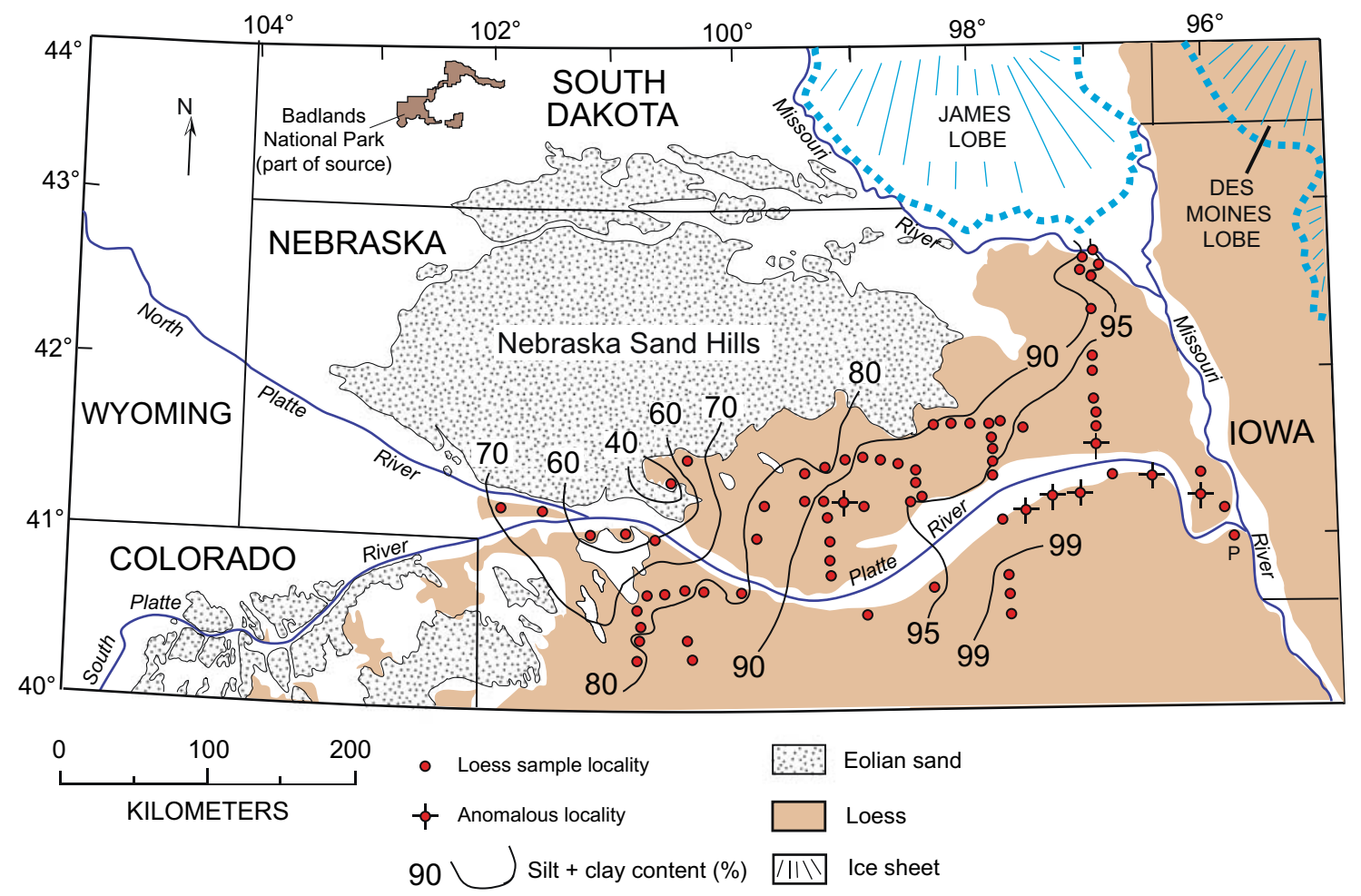

Fig. 18. Map showing the distribution of aeolian sand (black and white stippled areas) and loess (brown) in Nebraska and adjacent states, along with contours of percentage of fine grains (silt and clay) as a function of distance southeast of the Nebraska Sand Hills. Anomalous localities (localities with values less than the contoured values) are shown with crosses and are mostly near the Platte River. Also shown are nearest lobes of the Laurentide ice sheet during the last glacial period (Fullerton et al., 2003, 2004). and Badlands National Park, South Dakota, where the source of loess, the volcaniclastic siltstone White River Group, is well exposed. Redrawn from data in Muhs et al. (2008a).

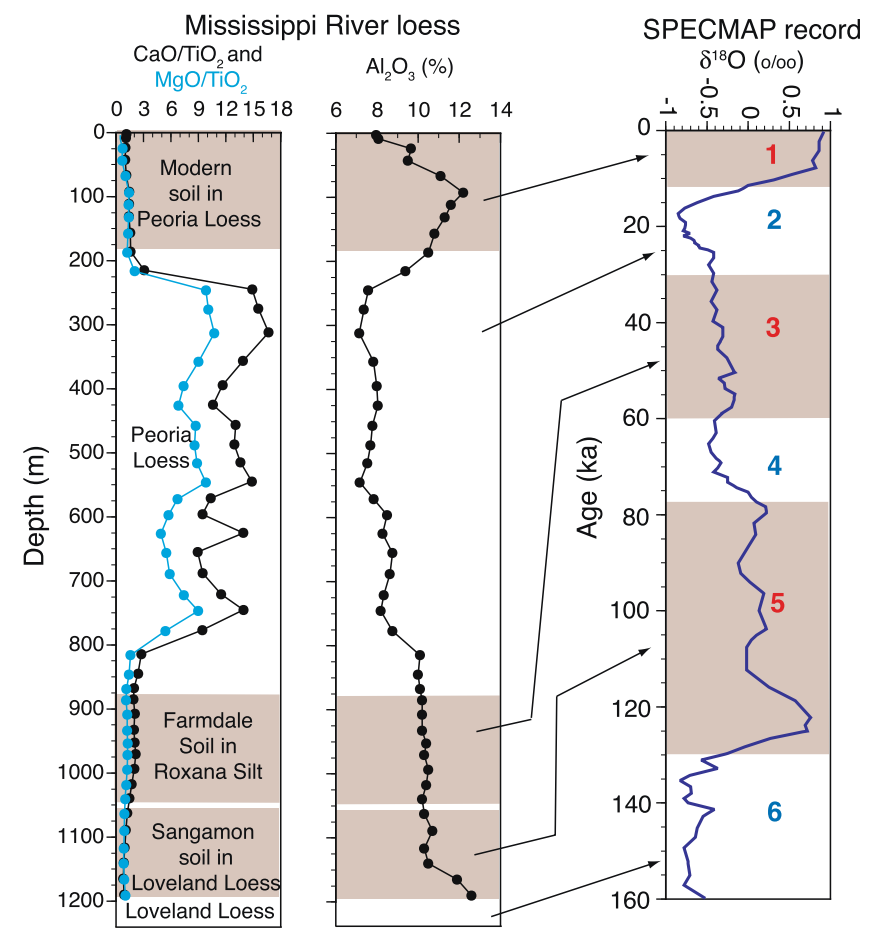

Fig. 19. Loess stratigraphy at Greenbay Hollow, Illinois (see Fig. 16 for location), which is typical for midcontinental North American loess sequences along the Mississippi River, showing changes in chemical properties in loess units and paleosols (data from Muhs et al., 2001). Also shown is proposed correlation of loess units with the SPECMAP deep-sea oxygen isotope record of Martinson et al. (1987).

\subsection{Loess stratigraphy in China}

In China, the alternation of loess and paleosols also has been correlated with the deep-sea oxygen isotope record of glacialinterglacial cycles, but the situation is more complicated than in mid-continental North America. Although the general model of loess deposits correlating with glacial periods and paleosols correlating with interglacial periods has general validity, in reality Chinese loess stratigraphy is rarely simple. Dust deposition occurs, albeit at a lower rate, during interglacial periods, such as the present, and adds fine particles to modern surface soils. Some loess alteration takes place, even during glacial periods, when loess sedimentation is most active. A useful concept for Chinese loess origins is to visualize loess sedimentation and soil formation as essentially competing processes (Verosub et al., 1993). When loess sedimentation rates are high, pedogenic processes cannot keep up and relatively unaltered sediment accumulates. When loess sedimentation rates are low, soil-forming processes extend deeper into previously deposited loess, but soils may also continue to accumulate small amounts of aeolian sediment during pedogenesis. Thus, whereas in deep-sea or lacustrine sediments, a case can be made for more-or-less continuous sedimentation (although at varying rates), loess-paleosol sequences should not be viewed in the same way.

China probably contains the longest and most continuous records of loess deposition in the world. In fact, loess deposition began long before the Quaternary Period. The Quaternary loesspaleosol successions on the Chinese Loess Plateau are underlain by what has been called the "red clays." Sun et al. (1998), using paleomagnetic methods, show that the red clays are as old as $\sim 7.2$ Ma. Ding et al. (1998), using particle size and geochemical data, report that the red clays are likely of aeolian origin, thus 


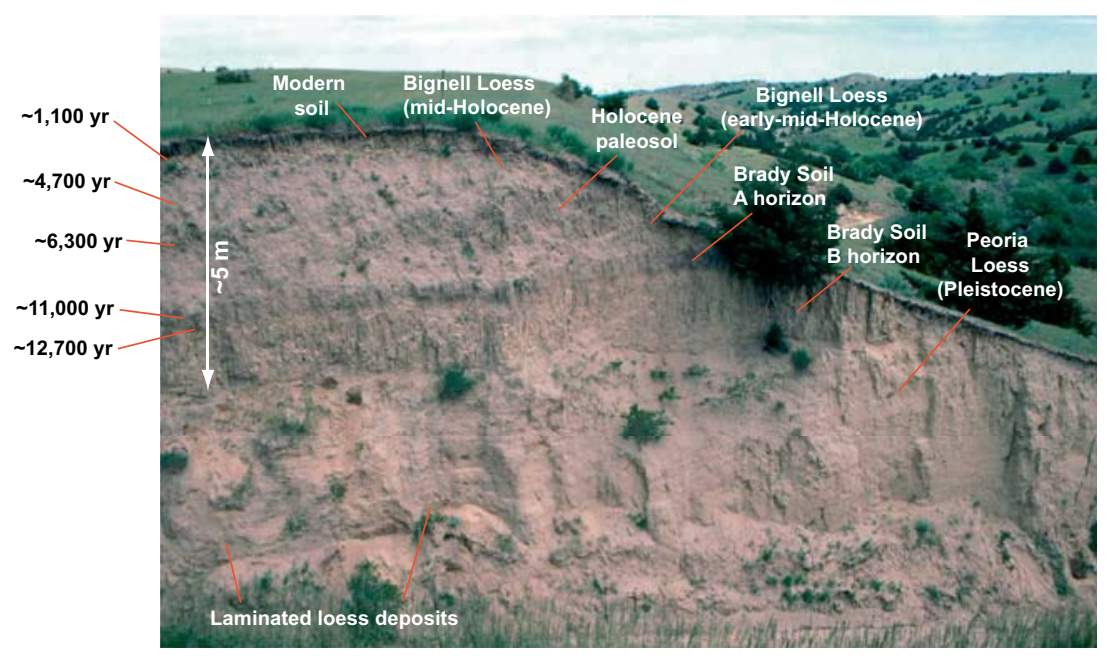

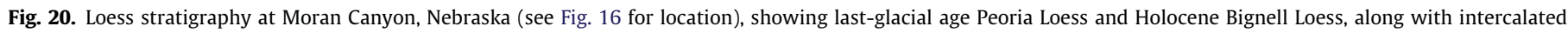
paleosols. Ages given are calibrated radiocarbon ages, from Muhs et al. (2008a). Photograph by D.R. Muhs.

inferring that atmospheric deposition of silts and clays in China is not strictly a Quaternary phenomenon. This observation is consistent with the deep-sea record of aeolian dust deposition in the Pacific Ocean, discussed later. The contact between the Tertiary red clays and the Quaternary loess is visually striking and sedimentation rates increased tremendously at the start of the Quaternary, $\sim 2.6 \mathrm{Ma}$. Sun and Zhu (2010) report that Pb-isotopic compositions of Tertiary red clay (as well as certain trace element concentrations) differ significantly from that of the overlying Quaternary loess-paleosol succession, with less radiogenic Pb-isotopic values in the younger part of the section (Fig. 21). They interpret these data to mean that aeolian source materials changed at the start of the Quaternary, with mountain glaciation exposing less radiogenic (presumably older) rocks that became the source sediments for Quaternary loess.

With the beginning of the Quaternary at $\sim 2.6 \mathrm{Ma}$, loess deposition alternating with periods of reduced sedimentation and soil formation began in China. Thirty-three loess-paleosol packages (with a couple additional, less well-developed paleosols) can be found above the Tertiary-Quaternary boundary at $\sim 2.6 \mathrm{Ma}$ at some sections, such as that at Jingchuan (Fig. 21). Loess deposits are typically light brown and silt-rich, whereas paleosols are redder, clay-rich and show considerable evidence of pedogenic structure.

In the Chinese stratigraphic nomenclature, loess deposits are preceded by an "L" and begin with the oldest unit, L33. Loess deposited during the last glacial period is L1, also called the Malan Loess. Paleosols are designated with an "S" prefix beginning with the oldest, which is S32, developed in L33. The paleosol that developed during the last interglacial period is called S1, and a Holocene paleosol is called S0. A good example of the stratigraphic sequence through the past four interglacial-glacial cycles is the relatively high-sedimentation-rate section at Baoji, China (Fig. 22). This section has loess and paleosol units that can be readily correlated with the deep-sea oxygen isotope record of the past four interglacialglacial cycles.

China is the region most often cited as the best example of a long-term and spatially extensive non-glacial (or "desert") loess record (e.g., Pye, 1987). A desert origin for Chinese loess is inferred from loess thickness and sand content trends that show decreases downwind from sandy desert basins (Fig. 17). However, loess in China may have, as its ultimate source, glacially derived silt. The mountains surrounding the largest desert basins in China have glaciers at present and were more extensively glaciated in the past

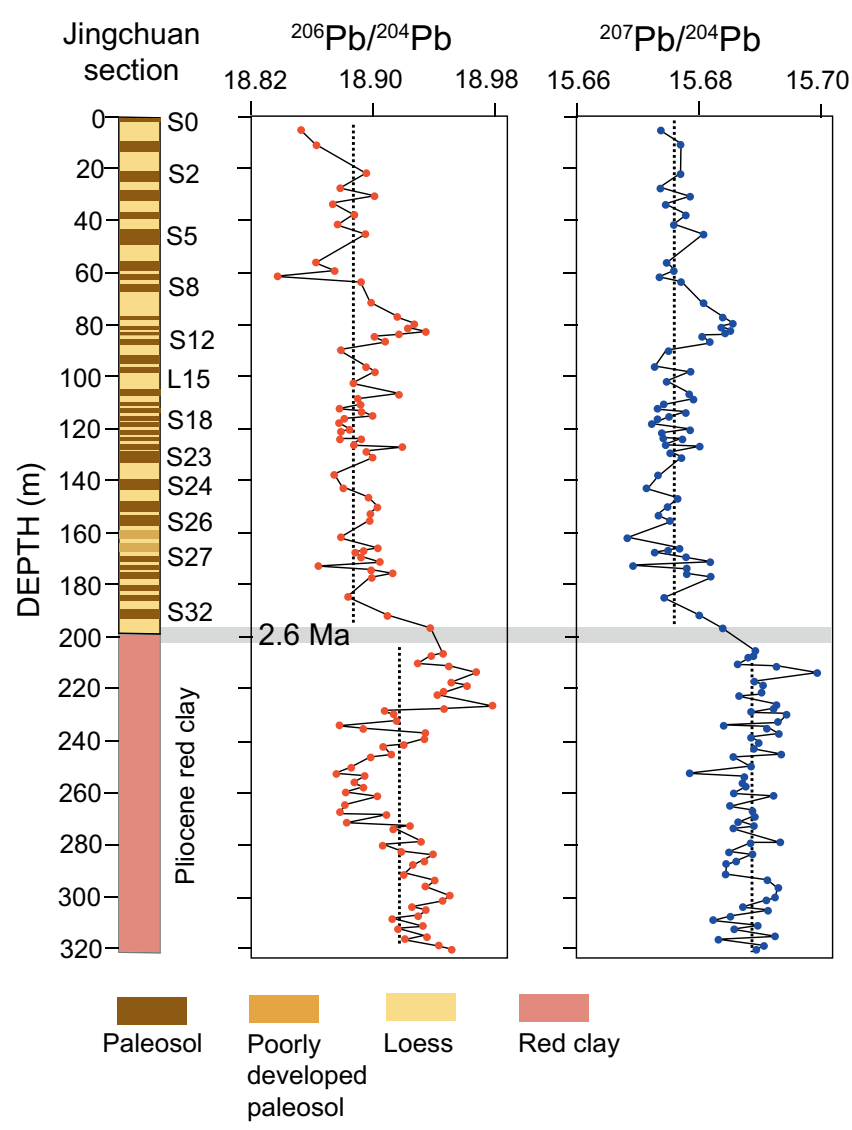

Fig. 21. Loess stratigraphy at Jingchuan, China (location shown in Fig. 10), showing Pliocene red clays overlain by succession of Quaternary loess units and paleosols. Also shown are Pb-isotopic plots, showing changes in source sediments at the Pliocene-Pleistocene boundary at $\sim 2.6 \mathrm{Ma}$. Redrawn in simplified form from Sun and Zhu (2010).

(Zhou et al., 2004). Thus, it is possible that much of the primary silt production took place in the mountains, by glacial grinding and frost shattering, followed by fluvial transport as outwash into the desert basins (Smalley, 1995), and finally entrainment from the basins by wind. Sun (2002a) reports that the loess on the mountains surrounding the desert basins, such as the Taklimakan Desert in 


\section{Baoji, China loess section

$\begin{array}{cc}\text { Clay-to-silt } & \text { Pacific core } \\ \text { grain size ratio } & \text { V28-239 } \\ (<2 \mu \mathrm{m} \text { to }>10 \mu \mathrm{m}) & \delta^{18} \mathrm{O}(\mathrm{o} / \mathrm{oo})\end{array}$
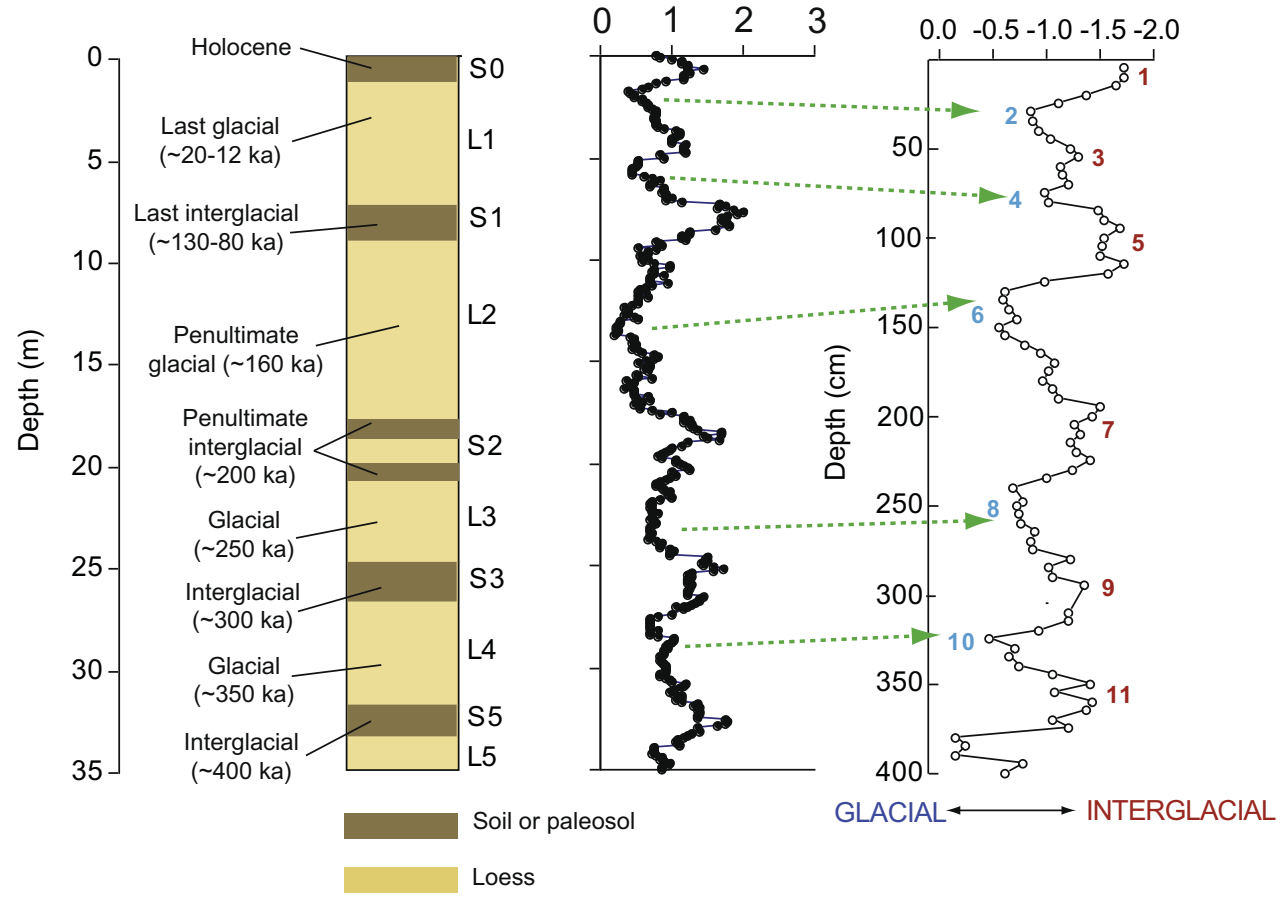

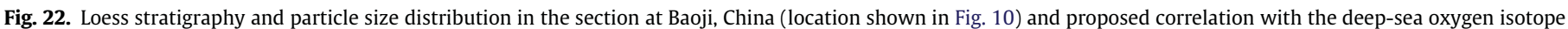

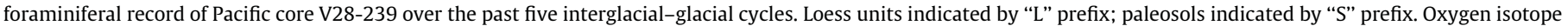

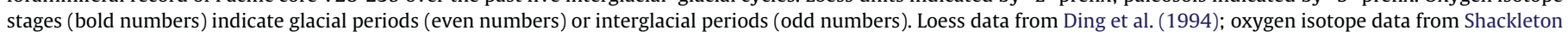

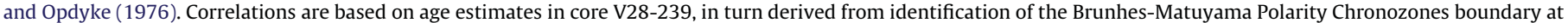
$726 \mathrm{~cm}$, an age for this boundary of $\sim 780 \mathrm{ka}$ (Spell and McDougall, 1992), and an assumed long-term average sedimentation rate of $\sim 0.93 \mathrm{~cm} / \mathrm{ka}$.

the Tarim Basin may have been deflated from the desert floor, but the silt-sized particles are derived originally from the very mountains on which they were re-deposited. Thus, his interpretation is that the arid basins of central China may simply act as reservoirs for fine particle storage and have little to do with silt production itself (Sun, 2002a,b).

Numerous researchers interpret the Chinese loess-paleosol successions as recording the alternating dominance of the two principal air masses that reside over eastern Asia described earlier (Fig. 10). These contrasting air masses at present control the delivery of modern dust to the region. In winter, the region is dominated by the Mongolian high-pressure system, which delivers cold, dry air to China with strong, northwesterly winds. In modern summers, low pressure develops over the Asian continental interior and higher pressure over the western Pacific Ocean generates the East Asian Monsoon, with a landward flow of warm, humid air to China under gentle winds. As described earlier, little or no dust entrainment occurs under summer conditions of humid air, weak winds and abundant precipitation. However, under the summer East Asian monsoon, the hot, humid conditions are optimal for weathering and soil formation. During the Quaternary, glacial times probably saw a greater residence time of what is now a winter synoptic pattern (Porter, 2001). Under such conditions, dust entrainment would have been enhanced, loess deposition rates would have been greater and soil formation would be minimal. The opposite pattern would have prevailed during interglacial periods, with a relatively greater residence time of a summer-type of pattern and enhanced monsoonal airflow (Porter, 2001). Thus, in Chinese loess deposits, the grain size is dominated by silt-sized particles, the result of winter winds dominating for a longer period in the year and aeolian deposition keeping ahead of pedogenesis. In paleosols, although loess deposition continues, it does so at a lower rate, and the summer East Asian monsoon, with greater humidity, dominates for a longer period of time, favoring pedogenesis and accumulation of clay. Thus, in Chinese loess-paleosol sequences, loess deposits are dominated by silt-sized particles, whereas paleosols are dominated by clay-sized particles (Fig. 22). It is important to note, however, that the clay enrichments seen in the paleosols can be due to both primary, clay-sized particle deposition and/or clay accumulation by in situ weathering during periods of relatively slow sedimentation, such as warm, moist interglacials.

\subsection{Paleoclimatic and paleoenvironmental interpretation of loess deposits}

A number of aspects of loess-paleosol sequences make these deposits powerful tools for paleoenvironmental intepretations. The presence of loess itself implies that conditions in the source areas are optimal for fine particle entrainment and transport. This in turn implies that source areas are probably dry, minimally vegetated and have winds of sufficient strength to entrain particles. As discussed earlier, the spatial distributions of loess properties are useful for paleowind determinations. Loess thickness and particle size decrease downwind from a source. Using these trends, a source can be identified and one can infer paleowind directions, a powerful tool for reconstructing atmospheric circulation patterns of the past. Thus, loess thickness and particle size trends indicate last-glacial paleowinds from the west or northwest in mid-continental North America (Figs. 16 and 18) and particle size trends indicate northerly or northwesterly last-glacial paleowinds in China (Fig. 17). In regions where a loess source, such as a major river valley carrying glacial outwash, is not apparent, isotopic methods can be very useful in 
"fingerprinting" the loess source area (see Aleinikoff et al., 1999, 2008, for examples from North America; see Fig. 21 for China). Loess deposits are commonly the host sediments for the shells of minute gastropods (land snails), and have been used extensively for paleoclimatic interpretations in North America, Europe and China (Leonard, 1952; Leonard and Frye, 1954, 1960; Liu, 1985; Wells and Stewart, 1987; Rousseau and Kukla, 1994; Rousseau et al., 2000; Rossignol et al., 2004). These studies show that loess bodies of last-glacial age in North America, Europe and China all hosted extralimital northern species of snails, indicating cooler-than-modern conditions at the time of loess deposition. Whereas sedimentologic and paleontologic data in loess give information about glacial periods, paleosols within loess deposits yield information about interglacial or interstadial periods. The most common method applied to loess-derived paleosols, for paleoclimate studies, has been measurement of magnetic susceptibility and other mineral magnetic properties (Kukla and An, 1989; Verosub et al., 1993; Maher et al., 1994; Porter, 2001; Singer and Verosub, 2007). Nevertheless, there are some assumptions in this approach that require that paleoclimatic interpretations from magnetic data be interpreted with caution (Porter et al., 2001). Furthermore, in some regions, such as Siberia and Alaska, magnetic properties show the opposite relation to what they show in other regions, such as China (Begét et al., 1990). Soil morphology and chemical properties of paleosols also yield valuable information about paleoclimate, particularly humid vs. arid conditions, during times of pedogenesis (Ruhe, 1969; Grimley et al., 2003; Muhs et al., 2008b).

\section{Lacustrine records of dust deposition}

Lakes are perhaps one of the most underutilized archives of dust deposition. In principle, lakes should potentially contain some of the best records of dust deposition because of a number of reasons: (1) they are widely distributed over much of the Earth's land surface; (2) they commonly contain materials suitable for radiocarbon dating; and (3) they contain abundant complementary paleoclimatic proxy data, such as pollen, ostracodes, phytoliths, diatoms, and other biologic materials. One of the problems, however, is that lakes also receive terrestrial sediment by other means, such as fluvial and colluvial processes. Thus, the investigator must ascertain which terrestrial components in a lacustrine sediment core are truly aeolian and which are derived from other transporting processes. This becomes particularly challenging when other geomorphic processes deliver particles that are within the size range of dust particles.

One approach to overcoming the problem of sediments of mixed origin in lakes is to choose study areas that are situated entirely in a bedrock terrain that has a composition differing from typical dust particles. Dust and loess usually have compositions that are close to that of average upper continental crust (Taylor and McLennan, 1985). Thus, lakes found in mafic volcanic terrains (basalt or andesite) should not contain fine-grained particles that have average upper continental crustal compositions except those contributed from the atmosphere. Mineralogy and geochemistry can therefore identify these components. For example, St. Michael Island, Alaska consists largely of basaltic terrain and contains several maar lakes, such as Zagoskin Lake, studied by Muhs et al. (2003b). Because these are lakes with relatively limited drainage inputs in a dominantly basaltic terrain, particles that have nonbasaltic compositions must have been derived from the atmosphere. Particles are fine-grained in Zagoskin Lake, with mean diameters ranging from $\sim 5 \mu \mathrm{m}$ to $\sim 15 \mu \mathrm{m}$ (Fig. 23 ). In the absence of glacial grinding, it is not common for basalt particles to weather (chemically or mechanically) to this particle size. Ratios of majorto-trace elements ( $\mathrm{Ti} / \mathrm{Zr}, \mathrm{K} / \mathrm{Rb}$, and $\mathrm{Ca} / \mathrm{Sr}$ ) show that Zagoskin Lake silts have compositions significantly different from the local basalt, but fall within the range of loess deposits on the nearby Seward Peninsula (Fig. 23). Identification of the lake's particles as aeolian
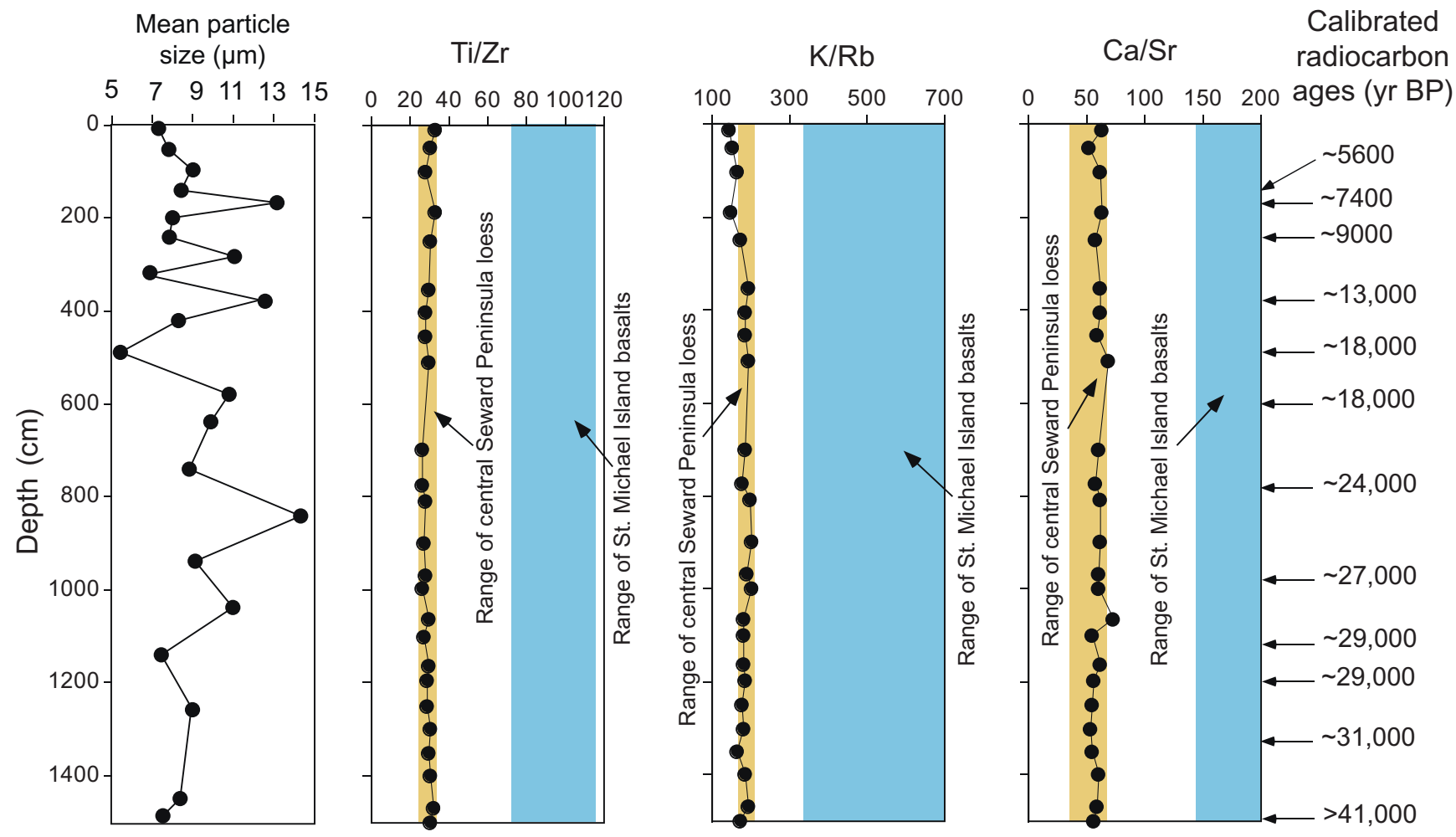

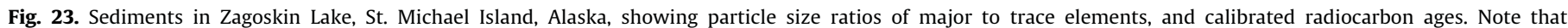

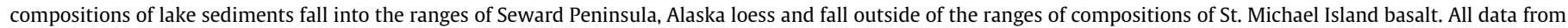
Muhs et al. (2003b). 


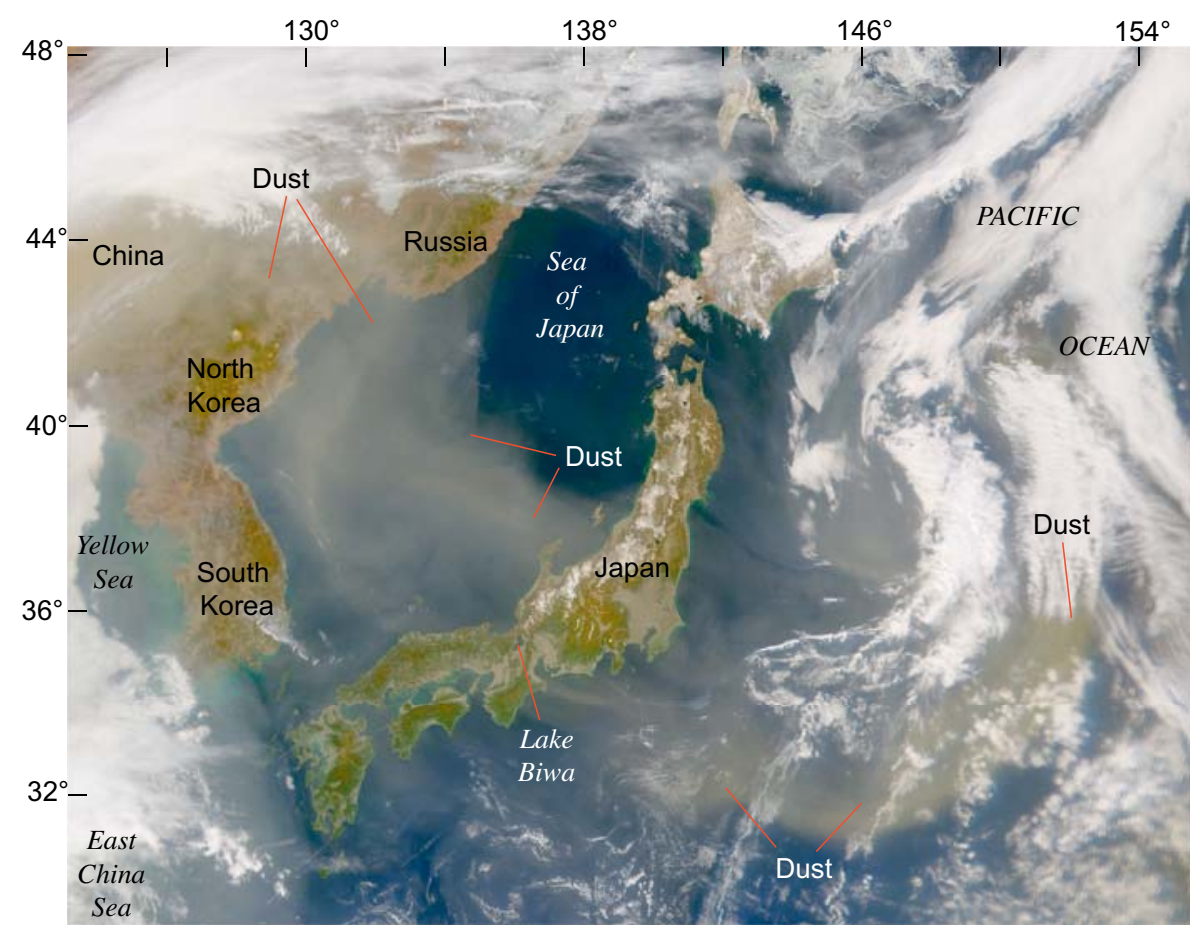

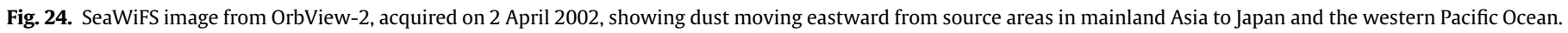

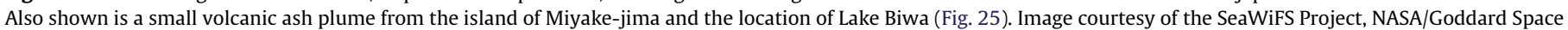
Flight Center and ORBIMAGE.

leads to the observation that linear aeolian sedimentation rates were higher during the last glacial period than during the Holocene. Furthermore, aeolian particle accretion in the lake is a process that has been ongoing for perhaps as long as $\sim 40 \mathrm{ka}$. The findings are interesting in that much of interior Alaska does not preserve many records of significant loess accretion during the last glacial period (Muhs et al., 2003a). Holocene loess and pre-last-glacial loess records are abundant, but loess dating to the last glacial period has been elusive. Muhs et al. (2003a) speculate that during the LGM, abundant loess might have been generated by expanded glaciers in Alaska's mountain ranges. Nevertheless, a cold, dry, windy, and sparsely vegetated LGM landscape might not have provided a favorable environment for loess preservation. Thus, lake records such as that at Zagoskin Lake might provide a key archive for documenting significant dust generation during a period when the loess record would indicate otherwise.

Aeolian records in maar lakes have been studied elsewhere, particularly in parts of western Europe where such features are common. Maar lakes and dry maars are abundant in westernmost Germany, between Bitburg and Bonn, to the southwest of the Rhine River. Dietrich and Seelos (2010) report results of aeolian sediment studies from the Dehner dry Maar situated in the Eifel area in western Germany. The sediment record here extends from $\sim 40 \mathrm{ka}$ to $\sim 13 \mathrm{ka}$. Devonian carbonate terrains are situated to the east of the study area and therefore clastic carbonate particles found in the maar imply aeolian transport from the east. The sedimentation rate is high enough that Dietrich and Seelos (2010) were able to report the frequency of easterly carbonate-dust bearing winds per century over the last glacial period and extending back to $\sim 40 \mathrm{ka}$.

One of the best lacustrine records of dust accretion over a longer timescale comes from Asian dust inputs to Japan. Xiao et al. (1997) studied sediments in Lake Biwa, the largest lake in Japan, situated on Honshu Island. Based on examination of modern satellite imagery, Lake Biwa receives dust from the same sources in Asia that ultimately supply LRT dust to the Pacific Ocean (Fig. 24). Xiao et al. (1997) provide data on a 50-m-long core from Lake Biwa that

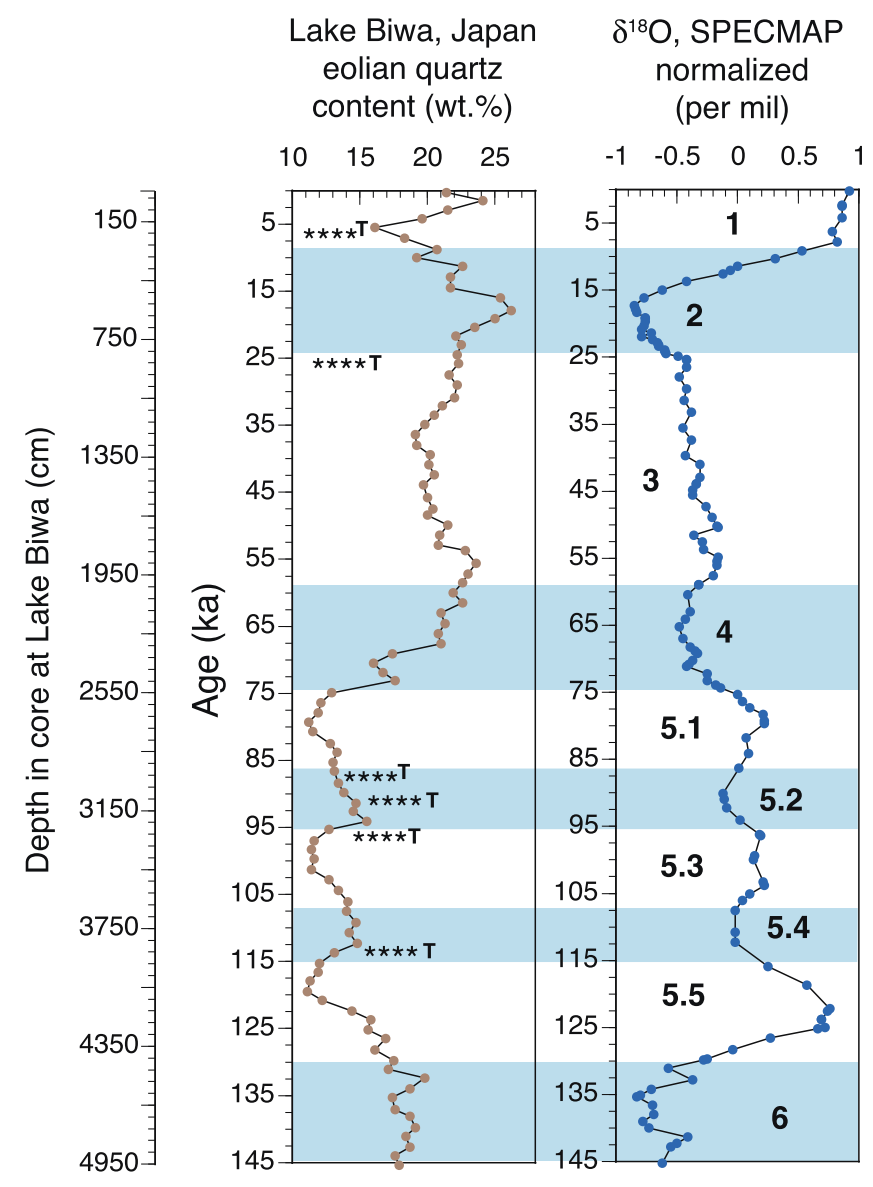

Fig. 25. Aeolian quartz content in Lake Biwa, Japan (see Fig. 24 for location) and correlation of fluctuations of aeolian dust content with the SPECMAP deep-sea oxygen isotope record of Martinson et al. (1987). Lake Biwa data from Xiao et al. (1997). 
has excellent age control based on the presence of several widespread tephras. These workers isolated quartz from the sediments and determined oxygen isotope compositions, with comparisons to Chinese loess, confirming that the quartz is of Asian origin. The majority of particles are 1-10 $\mu \mathrm{m}$, which supports an interpretation that these sediments are LRT dust. In a record that spans the past $\sim 145 \mathrm{ka}$, Xiao et al. (1997) report that aeolian quartz abundances show maxima during MIS 2, early MIS 3/MIS 4, and MIS 5.2, 5.4, and 6 (Fig. 25). In a following study, Xiao et al. (1999) correlate these periods of maximum dust flux with the major periods of loess deposition on the Chinese Loess Plateau. The Lake Biwa record is so detailed that it is one of the few aeolian dust records, found on land, that resolves brief periods of increased dust flux during short, cold episodes (MIS 5.2 and 5.4) of the last interglacial complex.

Lakes can also provide valuable archives of dust flux on more recent timescales. A good example of this is a recent study by Neff et al. (2008) of alpine lakes in the San Juan Mountains of Colorado. Aeolian dust was identified by its particle size and compositional differences, using $\mathrm{Nd}$ and $\mathrm{Sr}$ isotopes, from the local bedrock in the lake catchment areas. With sediments dated by ${ }^{210} \mathrm{~Pb}$ and radiocarbon methods, these workers present a $\sim 5,000$-yr-long record of aeolian particle flux into high-altitude lakes of the San Juan Mountains. Neff et al. (2008) report that dust fluxes increased by $\sim 500 \%$ over the late Holocene average following the settlement of the western USA in the 19th century. Although the Holocene record demonstrates that dust flux is a natural part of sedimentation in this region, Neff et al. (2008) suggest that the higher historic rate is due to livestock grazing and associated rangeland degradation.

\section{Records of dust in soils}

\subsection{A general concept for soils as archives for dust}

Because soils affected by dust inputs may cover significant parts of the Earth's land surface, archives of dust in soils are some of the most important records we have. Nevertheless, identification of dust inputs to soils is also one of the most challenging problems to solve. The major issues result from the fact that the degree of aeolian particle influence on soil development varies widely and the identification of exotic dust particles often requires detailed mineralogical, geochemical and isotopic analyses.

It is useful conceptually to place soils in a continuum that displays varying degrees of aeolian influence, an idea articulated by Yaalon and Ganor (1973). Although these workers did not present this concept visually, I have attempted to illustrate their ideas in Fig. 26. At one end of the continuum, soils developed entirely in thick deposits of aeolian sediments can be identified in the field (Fig. 26a). Loess deposits with modern soils and paleosols (in older loess deposits) fall into this category. A decreasing aeolian influence would be soils that occur on non-eolian substrates, such as the lava shown in Fig. 26b, but with an identifiable aeolian mantle that the upper part of the soil is developed in. The soil that is visible in the field has developed in part from weathered lava fragments, but fine-grained, bedrock-free aeolian sediment occurs at the top, and the upper part of the soil is developed solely in this material. A common situation where this occurs is in areas that are downwind from thick loess deposits, where thin loess occurs over till or bedrock. With a further decrease in aeolian influence, a distinct aeolian mantle is lacking, but aeolian particles can be identified in the field, forming part of the matrix of the soil profile (Fig. 26c). This type of occurrence can be identified in the field where a soil may have fragments of bedrock or other non-aeolian parent materials found throughout the profile, but the matrix of the soil has fine-grained materials that did not come from the underlying substrate. A good

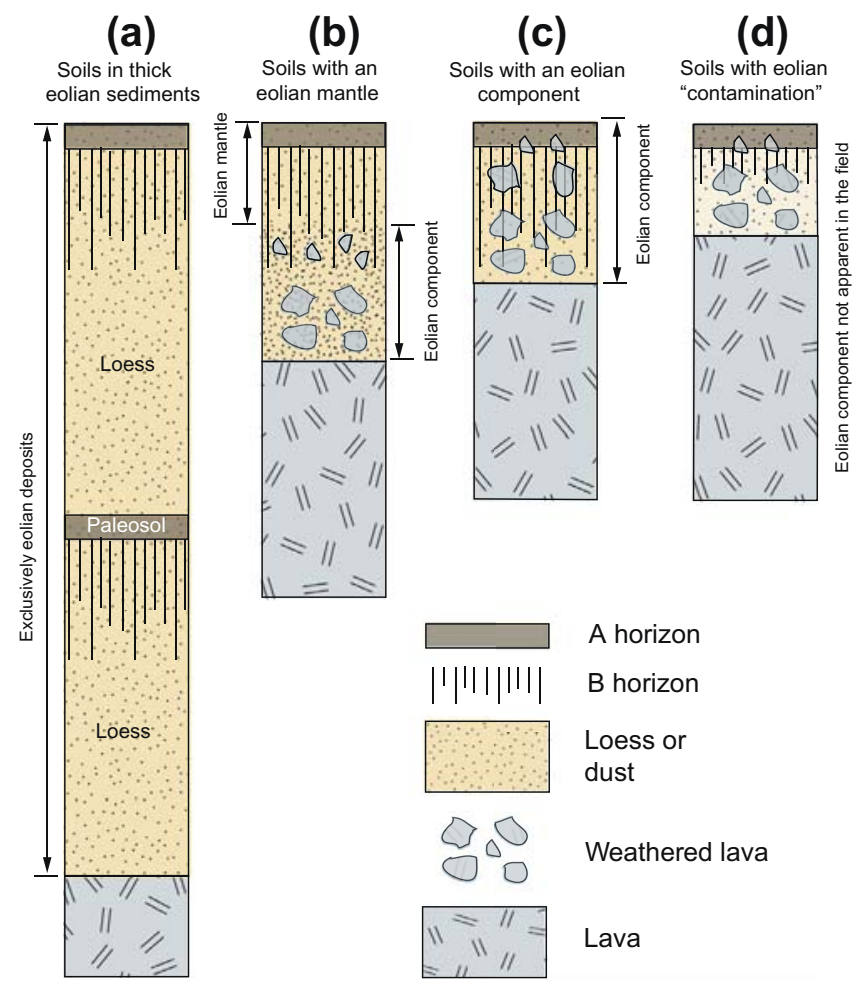

Fig. 26. Diagram showing a hypothetical field continuum of varying degrees of aeolian influence on soils, using concepts in Yaalon and Ganor (1973). (a) The modern soil and paleosol are developed entirely in aeolian sediment parent material, such as loess, with unaltered loess and bedrock (shown as lava) well below both. (b) The modern soil is developed solely in aeolian sediment in its upper part but in a mixture of weathered lava and aeolian sediment in its lower part; a geologic contact between aeolian sediment and bedrock is apparent in the field. (c) All of the modern soil is developed in a mix of aeolian sediment and weathered bedrock, but the aeolian component is recognizable in the field. (d) All of the modern soil is developed in a mix of aeolian sediment and weathered bedrock, but the aeolian component is not apparent in the field and can be discerned only by laboratory analyses.

example of this might be soils with well-developed carbonate-rich horizons found on a geologic substrate that could not have supplied the carbonate. Finally, the most complicated situation is where soils have experienced what Yaalon and Ganor (1973) refer to as "aeolian contamination" (Fig. 26d). Here, identification of an aeolian component is not apparent in the field, but an aeolian influence can be detected by analytical methods (mineralogical, geochemical, isotopic) that show materials exotic to the geologic substrate that occur within the soil profile.

Yaalon and Ganor (1973) give a number of examples of soils with varying degrees of aeolian influence in Israel. As alluded to earlier, dust reaches Israel from deserts in North Africa with regularity and has influenced soils there in a variable manner over very short distances (Fig. 14). In the western part of the country, in the northern Negev Desert, dust accretion occurs at a fairly high rate and soils have developed entirely within loess deposits. Loess is apparent as fine-grained aeolian sediment, and paleosols are distinguished by well-developed calcic horizons. On the other hand, only $\sim 100 \mathrm{~km}$ to the northeast, near Jerusalem, even thin loess deposits are absent. Nevertheless, Yaalon and Ganor (1973) hypothesize that much of the silicate component of red, clay-rich "terra rossa" soils on limestone bedrock is probably derived from LRT dust, as the bedrock contains little material that could accumulate as clay during pedogenesis. Thus, the two examples from Israel, only $\sim 100 \mathrm{~km}$ apart, serve to illustrate the two extreme end-members of the soils/aeolian influence continuum shown in Fig. 26. 
6.2. Examples of dust mantles in soils and aeolian "contamination" of soils

Despite its importance as a dust source (Fig. 8), Australia has little in the way of what most field geologists would identify as true unaltered loess deposits, as discussed earlier. Nevertheless, examples of aeolian mantles (Cattle et al., 2009; Greene et al., 2009) and aeolian "contamination" of soils are abundant in Australia, and occur over a widespread area in the southern part of the continent (Fig. 27). Hesse and McTainsh (2003) report that many methods have been used to identify fine-grained mantles that are likely of aeolian origin and exotic, aeolian components in soils where a dust influence is not apparent in the field. Examples of these methods include: (1) fine-grained (aeolian particle sizes) soils of similar

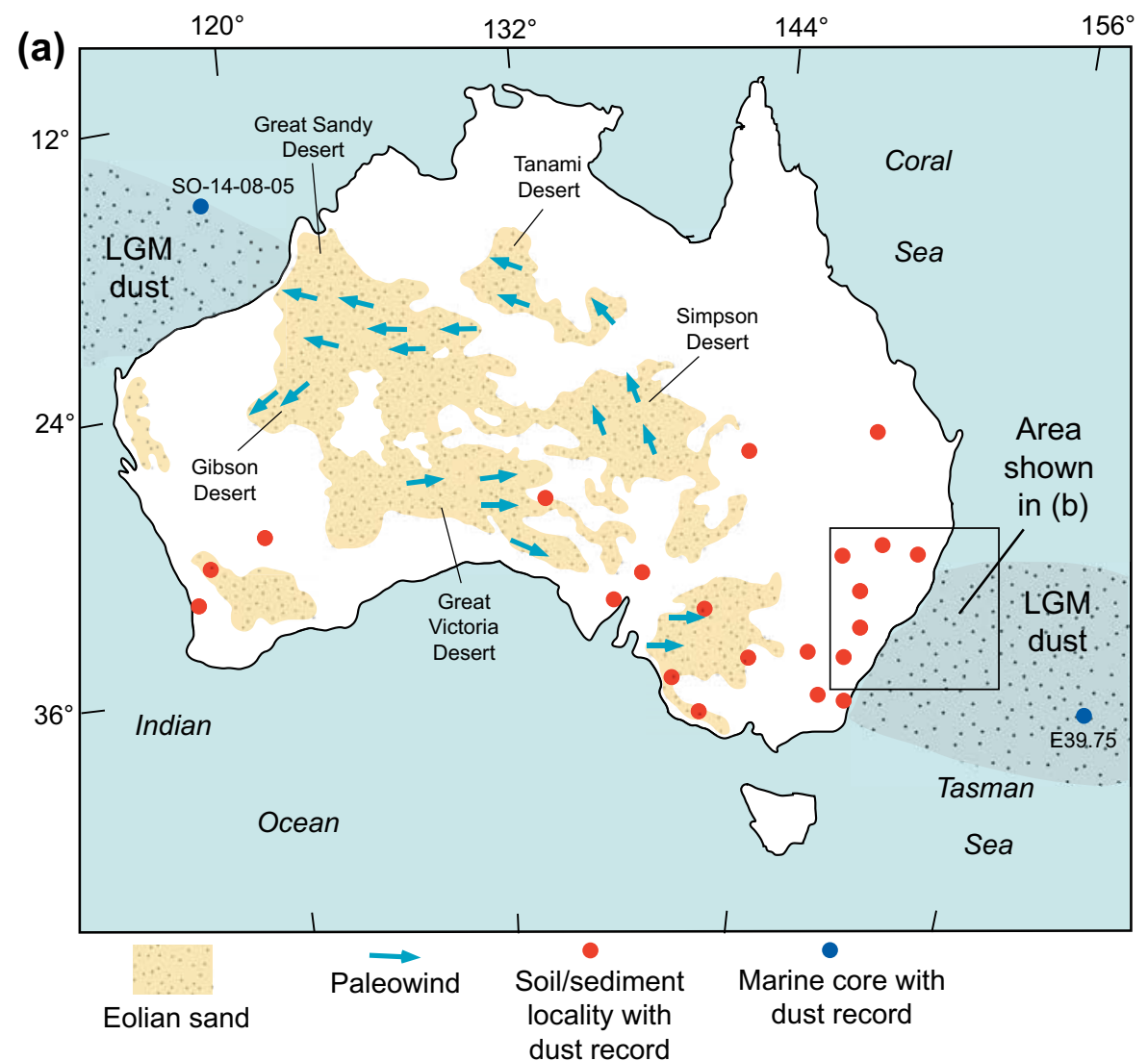

(b)

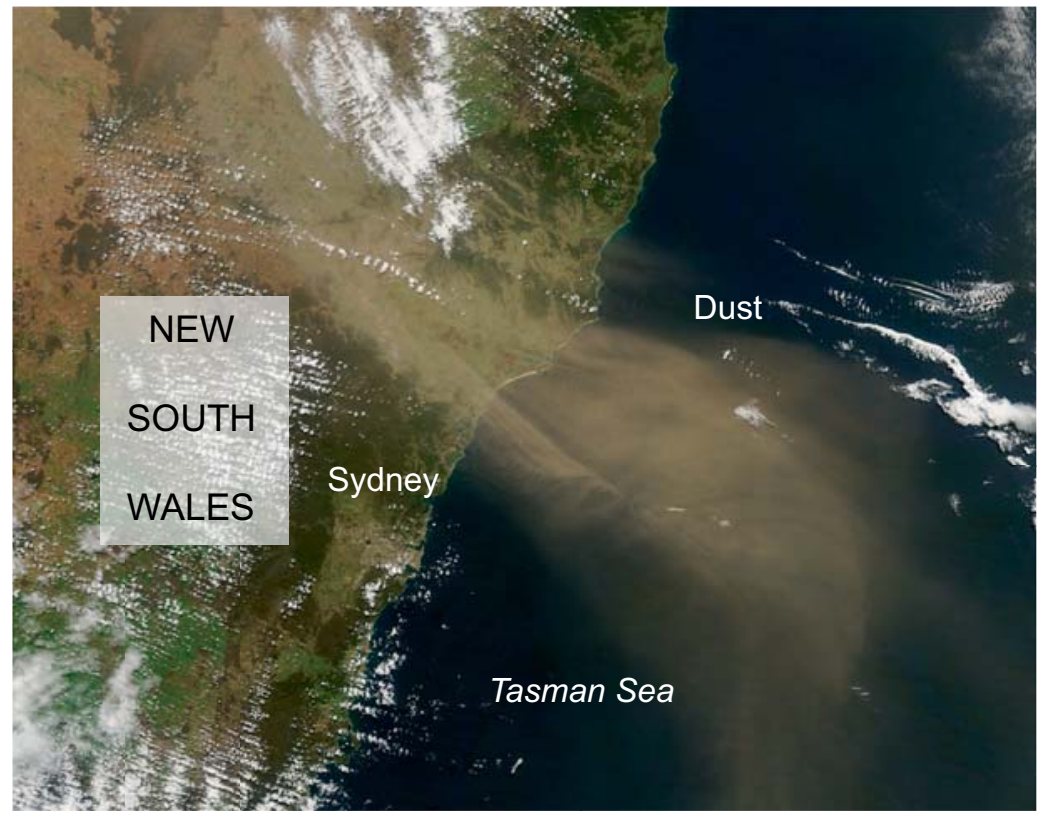

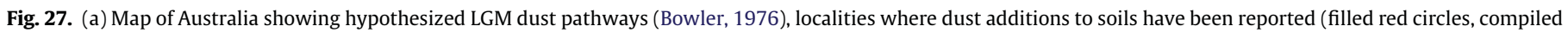

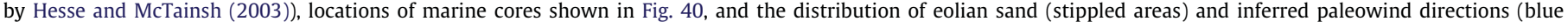

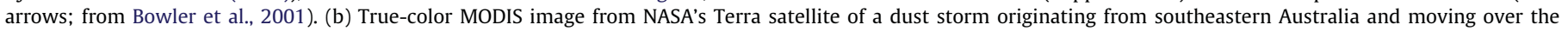
Tasman Sea on 13 October 2009. Satellite image courtesy of Jeff Schmaltz of the MODIS Rapid Response Team, NASA Goddard Space Flight Center. 
morphology that occur over very diverse bedrock types (particularly with sharp lower boundaries); (2) presence of quartz in soils that have developed on quartz-free basalt; (3) soil quartz with oxygen isotope ratios that differ from oxygen isotope ratios in quartz from the underlying substrate; (4) downwind decreases in particle size; (5) illite (mica) enrichment in the soils compared to the amount of mica in the geologic substrate; and (6) Ti/Zr values in soils that differ from those in the underlying substrate. Note that some of these approaches above $(1,2)$ may be successful in the field, but others $(3,4,5,6)$ require laboratory analyses.

As discussed earlier, the Saharan and Sahel regions of Africa are, at present, the most important sources of dust in the world (Figs. 7 and 8). It follows, therefore, that coastal regions of western Africa and the offshore islands (Canary Islands, Cape Verde Islands) are areas where soils could be expected to be influenced strongly by dust inputs. Recent field and laboratory studies by Von Suchodoletz et al. (2009) and Muhs et al. (2010) have confirmed that Lanzarote island, in the eastern Canary Islands (Fig. 7 and 9) has soils and paleosols that contain mineralogic and geochemical evidence of African dust inputs. Soils on volcanic flows have yellowishbrown colors, silt loam textures, lack pedogenic structure and resemble loess, examples of Yaalon and Ganor's (1973) concept of soils with a distinct aeolian mantle. Mineralogical studies confirm the presence of quartz and mica, neither of which occur in the island's basalt bedrock, but which are common components of African dust.

At other localities on the Canary Islands, there are carbonaterich aeolian sands, similar to the carbonate aeolianites of Quaternary age found on many tropical and subtropical landscapes. Meco et al. (2011) report on a thick sequence of these carbonate dune sands on Lanzarote island. Deposition of carbonate dunes on the Canary Islands was episodic, as shown by the presence of paleosols (Fig. 28). The aeolian sands are all dominated ( $\sim 85 \%$ or more) by carbonate minerals, calcite and aragonite, with the remainder being small amounts of basaltic sand. The aeolian sands were derived mostly from bioclastic marine sands that accumulated on the insular shelves and then were entrained by the wind during low stands of sea. Paleosols developed when aeolian sand sources were cut off during rising sea levels as interglacial periods began. However, the paleosols have much lower carbonate contents, but this is not due to carbonate leaching during pedogenesis. The soils contain silts and clays, and the presence of quartz in the paleosols indicates that they developed primarily by accumulation of LRT dust derived from Africa. Thus, the soils "grew upward," as dust accretion increased during interglacial periods (Fig. 28). The Lanzarote example is interesting in that it shows how fine-grained aeolian "contamination" (i.e., accumulation of LRT dust from Africa) can be hosted in coarse-grained sediments that are also aeolian.

African dust can be transported across the Atlantic Ocean to northern South America, the Caribbean region and the southeastern United States (Prospero, 1999; Prospero and Nees, 1977, 1986; Prospero and Lamb, 2003; Prospero et al., 1970, 1981). This LRT dust is extremely fine-grained, with virtually all particles less than $20 \mu \mathrm{m}$ in diameter, and most less than $10 \mu \mathrm{m}$ (Prospero et al., 1970). Of the $<10 \mu \mathrm{m}$ fraction, approximately half the particles have diameters $<2 \mu \mathrm{m}$. This fine-grained dust input likely has important effects on soils in the Western Hemisphere, particularly where very pure limestone terrains, common around the Caribbean basin, inhibit soil genesis. South of the Caribbean basin, Koren et al. (2006) have suggested that much of the Amazon forest is sustained by a single LRT dust source, the Bodélé depression. That hypothesis requires testing, but recent studies have shown that African dust is in fact an important component in soils around the Caribbean basin (Muhs et al., 2007a). For example, soils and paleosols on many of the islands in the Bahamas and Florida Keys are red, fine-grained materials (Fig. 29) that contain clay minerals

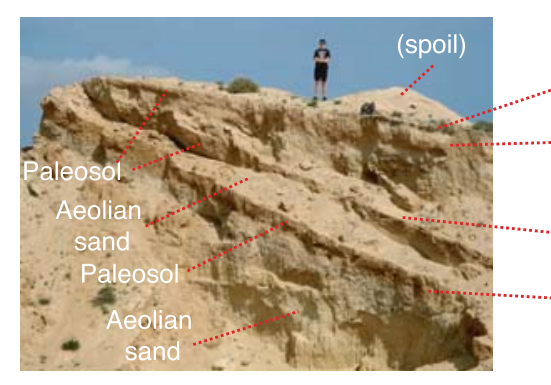

(c) Non-carbonate minerals (\%)

(a) Mala quarry, upper part of section

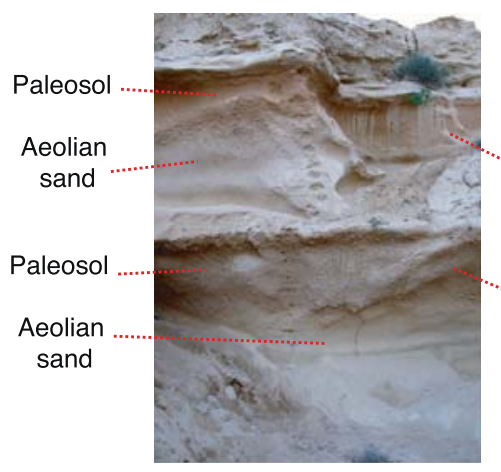

(a) Mala quarry, lower part of section
015304560
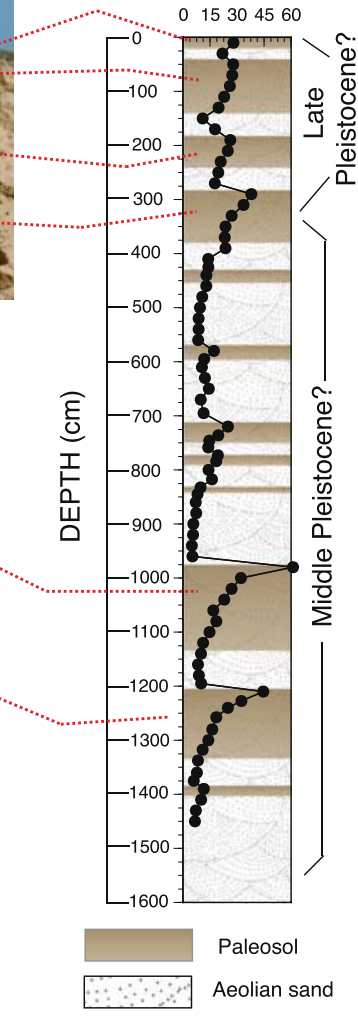

Fig. 28. Photographs and stratigraphy of the Mala quarry, Lanzarote (see Fig. 7a for location), Canary Islands, showing aeolian sands, paleosols and abundance of noncarbonate minerals (dominantly African dust), mostly in paleosols. Non-carbonate mineral data are from Meco et al. (2011); photographs by D.R. Muhs.

such as hydroxy-interlayered clay (a chlorite and/or vermiculite mixed-layer clay) and boehmite, an aluminum-rich clay mineral. Neither silica nor aluminum is present in the very pure carbonate coral reef and oolite substrates of Quaternary age found on the Florida Keys and the Bahamas. Trace element data reported by Muhs et al. (2007a) show that the red soils and paleosols on these islands are likely derived almost entirely from African dust.

Elsewhere in the Western Hemisphere, soils on islands provide a record of dust deposition from North America to the eastern Pacific Ocean. Although southwestern North America is a major dust source based on TOMS imagery (Fig. 8), Rea (1994, 2007) points out that North America actually provides very little dust to most of the Pacific Ocean. Nevertheless, under "Santa Ana" conditions in southern California and adjacent parts of Mexico, dust transport from the deserts of southwestern North America is directed westward, towards the eastern Pacific Ocean. In late fall, winter, and early spring, Santa Ana conditions develop after a high pressure cell settles into the Great Basin after the passage of a cold front, with resultant winds directed to the west along the coast of California and Baja California. Abundant dust can be entrained by what are sometimes extremely strong winds, and much of this dust ends up in the eastern Pacific Ocean, as seen on SeaWiFS imagery (Fig. 30). Thus far, little attention has been paid to possible dust inputs to the deep-sea sediment record in this part of the Pacific Ocean, but islands off the coast of California (San Clemente Island, and those in Channel Islands National Park) have soils with siltrich mantles. Several of these islands are wholly or mostly composed of volcanic rocks (andesite and basalt) whose mineralogy and geochemistry are significantly different from typical LRT dust. Muhs et al. (2007b, 2008c) used mineralogy (presence of quartz 


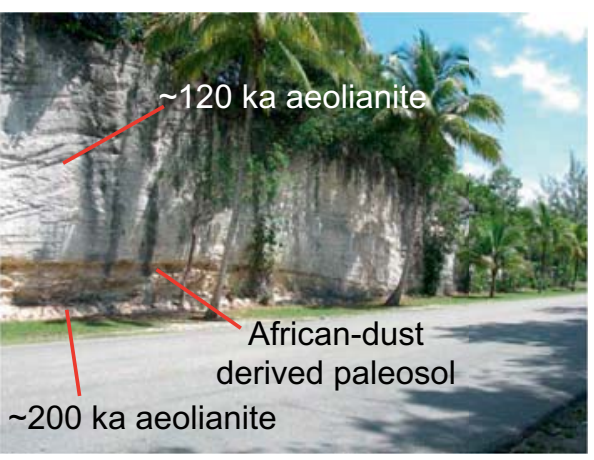

(a) Lyford Cay, New Providence Island, Bahamas

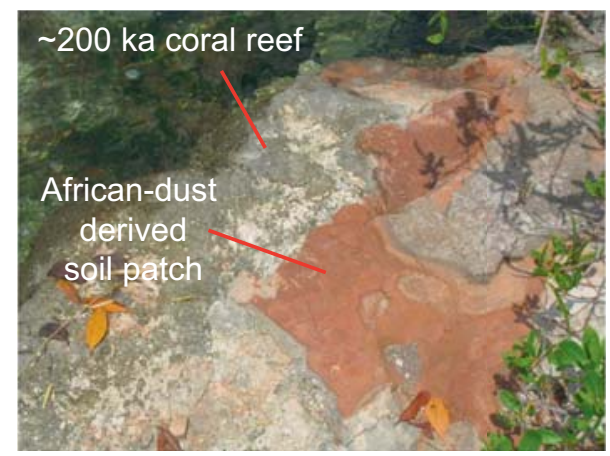

(c) Long Key, Florida

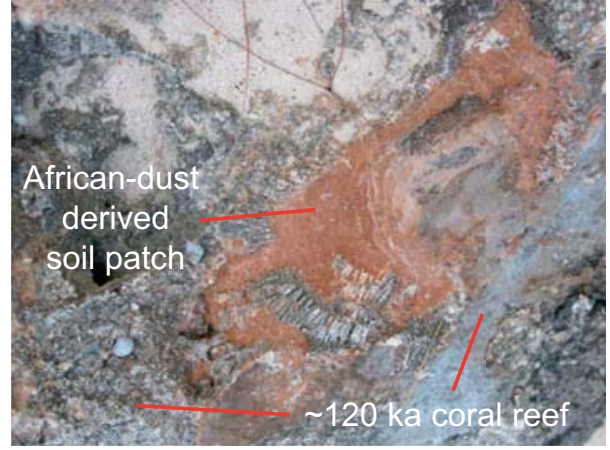

(b) West of Nassau, Bahamas

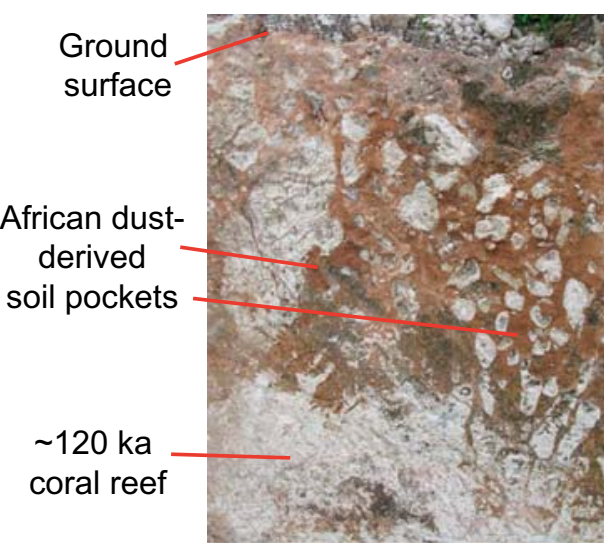

(d) Key Largo, Florida

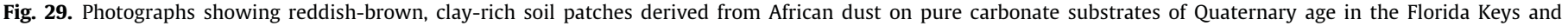
Bahamas. Data supporting an African dust origin for these soils are in Muhs et al. (2007a); all photographs by D.R. Muhs.

and mica) and trace element geochemistry (Sc-Th-La plots) to show that these silt mantles are not derived from the local bedrock, but are likely derived from Mojave Desert dust, or other upper continental crustal sources found on mainland North America (Fig. 31).

As will be discussed later, dust from Asia constitutes a significant portion of the fine-grained, non-carbonate fraction of deepsea cores in the North Pacific Ocean. Pacific Ocean island soils also have a record of Asian dust input. Rex et al. (1969) and Jackson et al. (1971) studied soils on the Hawaiian islands and found significant amounts of quartz, absent in the local basalt bedrock, in soils on Kauai, Oahu, Molokai, Maui and Hawaii. Quartz contents range up to $20-45 \%$ on Oahu, although contents are lower on the other islands. Oxygen isotope ratios in quartz from Hawaiian soils are similar to those in fine-grained quartz in Pacific Ocean marine sediments, indicating a common, Asian region of origin.

\subsection{The importance of dust for carbonate accumulation in soils}

One of the major findings of the past few decades is that calcareous dust plays a major role in the genesis of calcic and petrocalcic horizons (also called "caliche," "calcrete", "Bk horizons," and "K horizons") in soils. Landmark studies on the development sequence of carbonate accumulations in soils were from the US Soil Conservation Service Desert Project on soil geomorphology in southern New Mexico, during the 1960s, 1970s and 1980s. Gile et al. (1966), studying soils on progressively older geomorphic surfaces, found a systematic sequence of increasing pedogenic carbonate accumulation (Fig. 32). This sequence of development has now been recognized in many desert regions of the world, where the moisture balance is such that pedogenic carbonates are not leached through soil profiles. Ruhe (1967), who was a part of the same project in New Mexico, pointed out that in many cases, particularly where soils were developed in rhyolitic alluvium, there is simply too little calcium available for the genesis of calcic or petrocalcic horizons. Furthermore, there is little or no evidence that rhyolitic alluvium has experienced chemical weathering in this arid environment. The hypothesis was generated that dust additions could be the source of calcium carbonate in these soils. Dust traps were set up and monitored for a decade and the results indicate that calcareous dust accretion is significant in the region. Results of the long-term monitoring in this project are given by Gile and Grossman (1979) and indicate without question that calcareous dust fall rates are high enough to contribute significantly to calcic and petrocalcic soil horizon formation. Gile et al. (1981) report that calcium in precipitation is also an important contributor to carbonate accumulation in soils in the region, perhaps even more so than dust.

Other researchers have investigated the role of calcareous dust in the genesis of calcic and petrocalcic horizons in desert regions elsewhere. Reheis et al. (1995) conducted dust trap monitoring and examined soil chronosequences in arid regions of southern $\mathrm{Ne}-$ vada and southeastern California. They also found that calcareous dust plays an important role in the genesis of carbonate horizons of soils in this region. In addition, they report that non-carbonate components of dust, such as aluminosilicate clays, are also important in the development of these soils. Not surprisingly, upper horizons of soils are the most influenced by dust additions, with lower soil horizons being less influenced and more closely resembling compositions of the host sediment. Reheis et al. (1995) also report that last-glacial climates were more favorable in terms of moisture balance, compared to the Holocene, for translocation of both dustderived carbonates and aluminosilicate clays through soil profiles. 


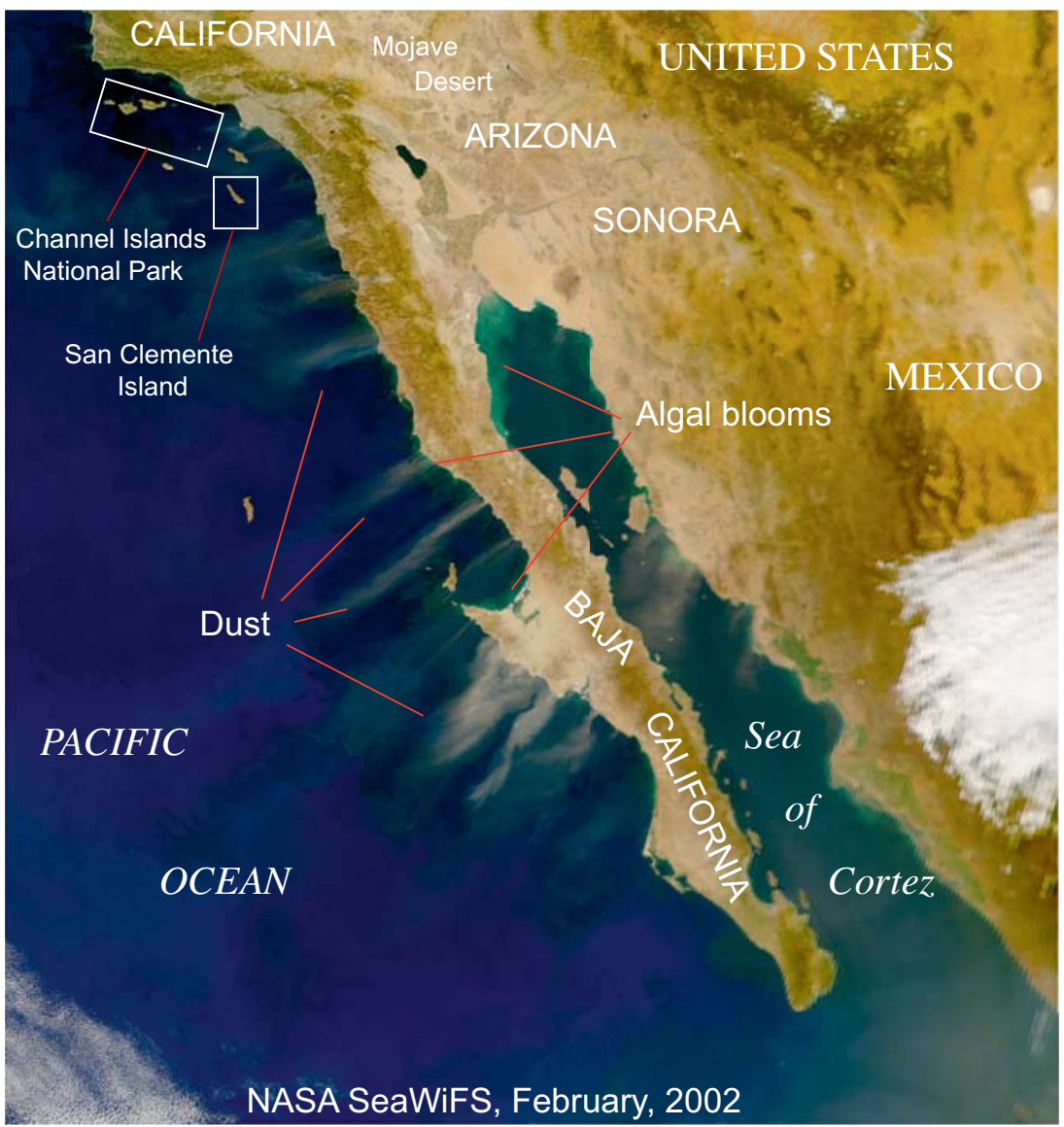

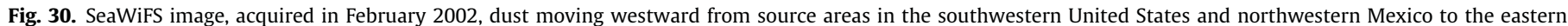

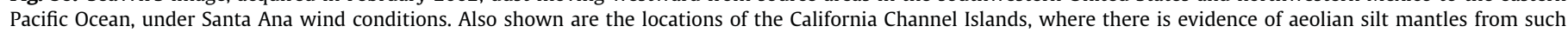
winds (Fig. 31). Note algal blooms in the Sea of Cortez and the Pacific Ocean. Image courtesy of the SeaWiFS Project, NASA/Goddard Space Flight Center.

\section{Marine records of dust deposition}

Marine sediment cores have been one of the most important sources of information about LRT dust and studies of aeolian particle input have been conducted in many parts of the world's oceans. Rea $(1994,2007)$ provides good reviews of the nature of the marine sediment record of dust deposition. Kohfeld and Harrison (2001) and Kohfeld and Tegen (2007) review the global record of last-glacial and Holocene LRT dust inputs to the world's oceans.

Marine sediments have a number of distinct advantages over other geologic records of dust input. First, they are widely distributed globally; thus, anywhere marine cores can be raised, the potential exists for obtaining an aeolian sediment record. Second, because of their setting on the ocean floor, marine sediment records generally lack unconformities, unlike terrestrial records. A potential problem they do have, as with terrestrial records, is sediment mixing from bioturbation, which tends to blur (but not necessarily delete) whatever sediment property is being sought. Third, because marine sediment cores usually contain foraminifera, it is possible to obtain an oxygen isotope record of glacial-interglacial cycles that provides a first-order chronology. Under favorable circumstances, an independent numerical chronology can be obtained, using radiocarbon, ${ }^{230} \mathrm{Th} /{ }^{232} \mathrm{Th}$, or tephrachronological methods. Finally, because marine sediment cores often contain other materials that can be studied (foraminifera, ostracodes, diatoms, pollen, alkenones, etc.), it is possible to develop highly complementary data sets from the same sample depths.

One major challenge in interpreting aeolian records in deep-sea cores is determining what proportion of the sediment population is truly aeolian. Ice-rafted particles, fluvial sediments and volcanic ash can all contribute to the sediment load that ultimately reaches the ocean floor. Fluvial inputs are a particularly important problem for cores taken along continental margins. Prins and Weltje (1999) and Weltje and Prins (2003) provide numerical-statistical algorithms that can be used to model end-member grain size distributions of the potential particle sources to continental margin sediments. Detailed particle size analyses, combined with these modeling techniques, allow investigators to separate the relative contributions of dust, turbidites, ice-rafted debris, etc. The method has been used with success in studies of aeolian sediments in marine cores off southwestern Africa (Stuut and Lamy, 2004; Stuut et al., 2002), off northwestern Africa (Holz et al., 2004, 2007; Filipsson et al., 2011; Meyer et al., 2011), off the coast of South America (Stuut and Lamy, 2004; Stuut et al., 2007), in the South China Sea (Wan et al., 2007), and in the eastern Mediterranean Sea (Hamann et al., 2008).

\subsection{Marine sediment records of dust in the Atlantic Ocean}

Many studies of LRT dust input to the Atlantic Ocean have been conducted. As early as the 19th century, Charles Darwin observed an 1833 dust fall aboard the Beagle in the Cape Verde Islands off the coast of West Africa. He recognized from this experience that wind-blown dust from Africa might be a significant contributor to Atlantic Ocean deep-sea sediments (Darwin, 1846). A pioneering modern study by Kolla et al. (1979) examined the abundance of quartz in Holocene and LGM marine sediments in the Atlantic Ocean. These workers report higher LGM quartz contents com- 


\section{Santa Cruz Island}
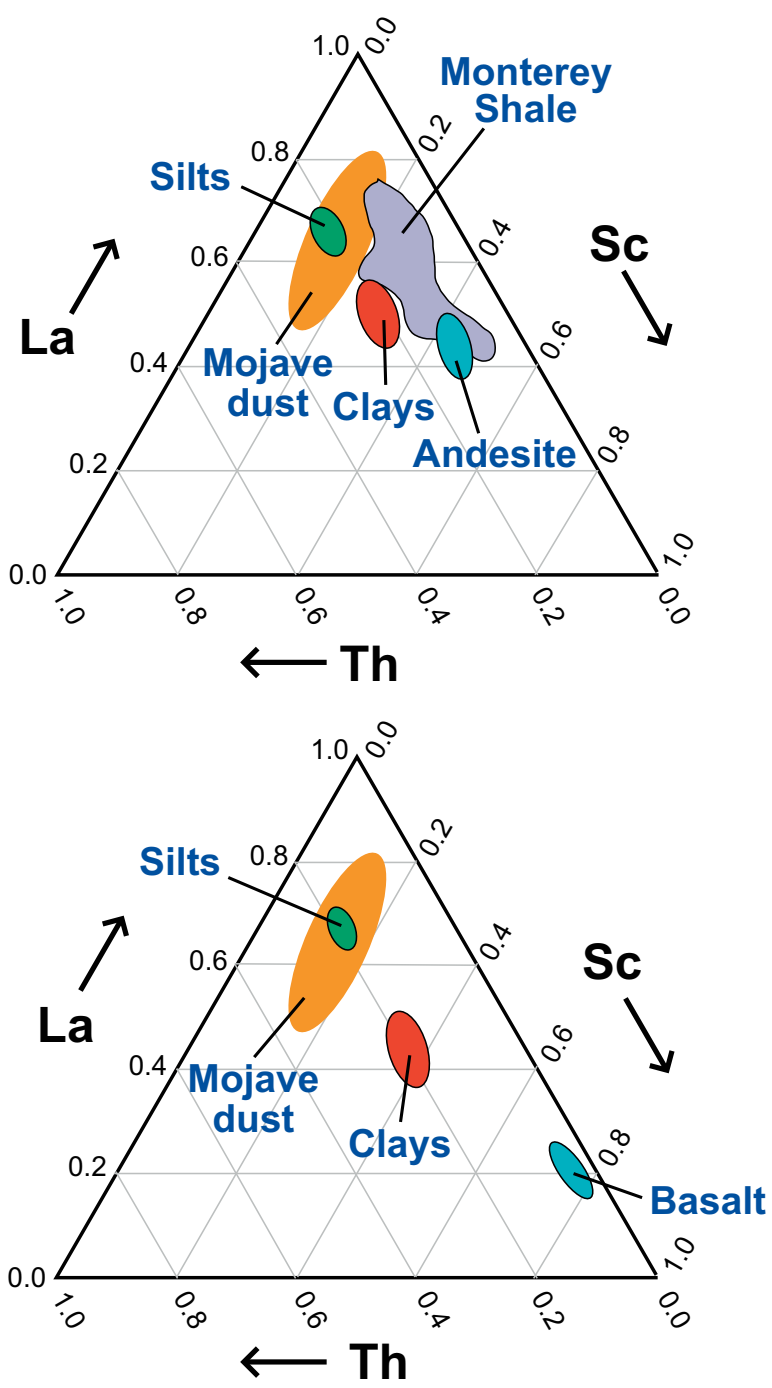

Santa Barbara Island

\section{San Clemente Island}
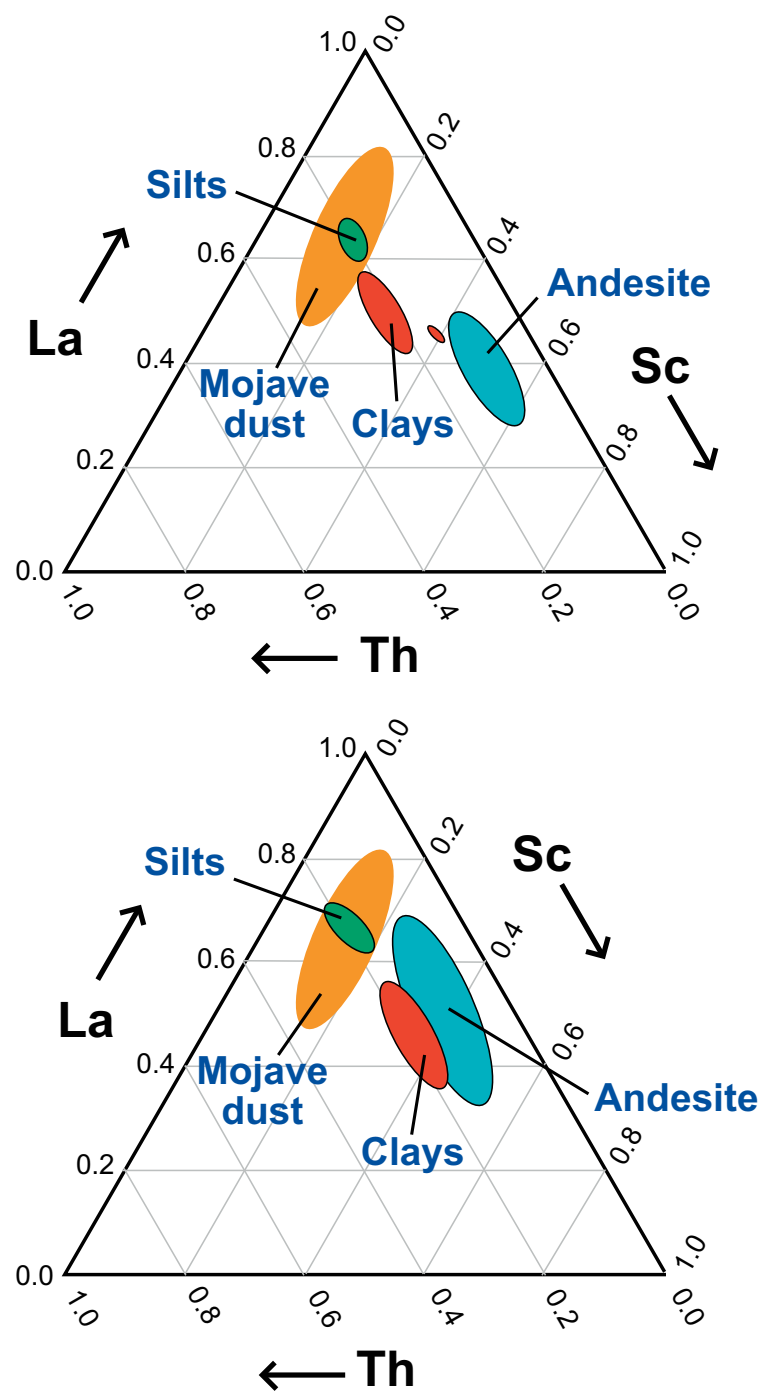

East Anacapa Island

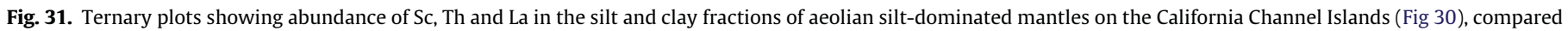
to local bedrock and Mojave Desert dust. Data from Reheis et al. (2002), Reheis (2003) and Muhs et al. (2007b, 2008c).

pared to the Holocene in the Norwegian Sea, the central and eastern North Atlantic Ocean, and the eastern equatorial Atlantic Ocean. The higher quartz contents in LGM sediments of the Norwegian Sea and the North Atlantic Ocean are explained by ice rafting, but this process does not explain the abundance of LGM quartz compared to the Holocene in equatorial regions. The maximum differences in quartz content in the equatorial Atlantic Ocean occur off the coast of West Africa and decrease westward. From this observation, Kolla et al. (1979) infer a greater input of LRT dust from Africa to the Atlantic Ocean during the LGM compared to the Holocene. Subsequent studies, most recently compiled by Kohfeld and Tegen (2007), show that mass accumulation rates (MARs) of LRT dust to the Atlantic Ocean off West Africa were 2-5 times higher during the LGM compared to the Holocene.

Support for higher dust flux due, at least in part, to increased strength of the trade winds during cold glacial periods comes from both aeolian and biological records in cores off Africa. Romero et al. (2008) and Filipsson et al. (2011) studied a core (GeoB 7926-2; see
Fig. 9) taken off the coast of Mauritania that includes sediment deposited during last glacial period, the Bølling-Allerød warm period, the Younger Dryas cold period and the Holocene. Using the end member modeling approach of Prins and Weltje (1999), they interpret coarser particles to be aeolian, with finer-grained particles to be of fluvial origin. The coarser-grained aeolian inputs were highest during the last glacial period and the Younger Dryas cold period (Fig. 33). During the Bølling-Allerød warm period and the Holocene, median particle sizes were reduced and are interpreted to represent a much greater fluvial input. Stronger trade winds are inferred to be the main cause of the higher aeolian inputs during the last glacial period and the Younger Dryas. Romero et al. (2008) and Filipsson et al. (2011) reason that if that interpretation is correct, enhanced upwelling should accompany an increased strength of the trade winds. A response to intensified upwelling is an increase in primary marine biological productivity, which should be reflected in a higher concentration of diatoms during such periods. The diatom abundance record from core GeoB 7926-2 matches 


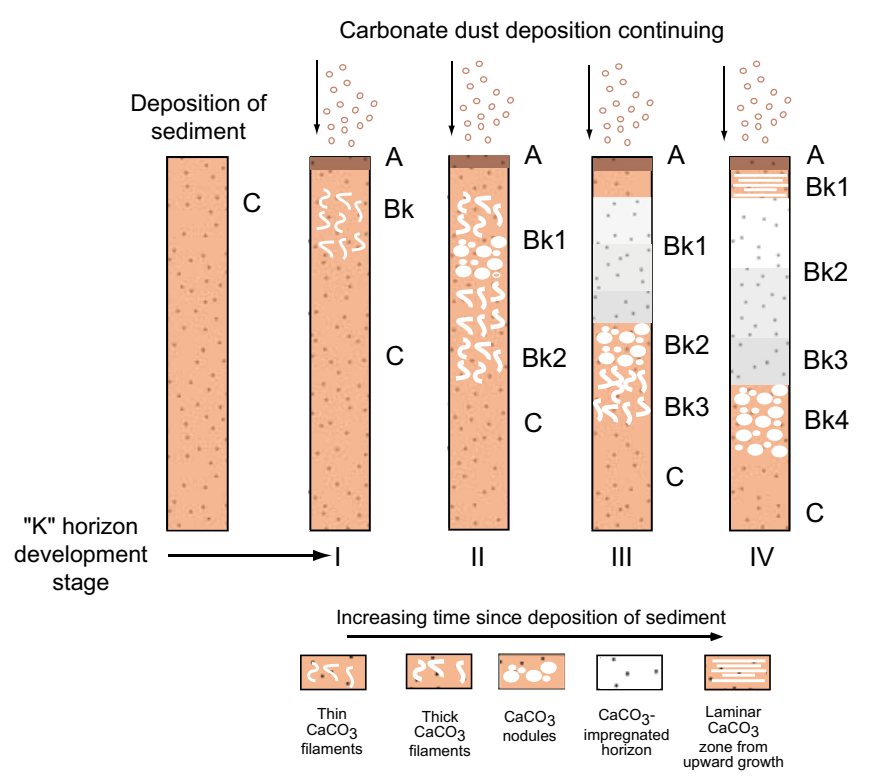

Fig. 32. Model of carbonate horizon formation in soils through time, dominantly from additions of carbonate dust (Gile and Grossman, 1979; Gile et al., 1981), based on concepts given in Gile et al. (1966).

the grain size record in the core very closely (Fig. 33) and demonstrates how climate change in this region elicits both aeolian and biological responses in the marine sediment record.

Detailed analyses of individual marine sediment cores also show a fairly consistent relation of higher dust deposition to the oceans during earlier glacial periods. A good example of this is from the Canary Basin off northwestern Africa, where dust inputs from both the northeast trade winds and the Saharan Air Layer are important (Fig. 9). Moreno et al. (2001, 2002) studied a marine sediment core from the Canary Basin that has a detailed record of glacial-interglacial cycles over the past $\sim 250 \mathrm{ka}$. The basic chronological framework is derived from oxygen isotope analyses of the biogenic carbonate fraction, which constitutes a majority of the bulk sediment, correlated to the SPECMAP oxygen isotope stratigraphy of Martinson et al. (1987). The most recent 8 marine isotope stages (MIS) can be easily recognized in this core (Fig. 34). Because the core is located well off the African coast and biogenic opal production is low, non-carbonate components in the sediment are interpreted to be dominantly aeolian. Aeolian particles are found throughout the record, with median particle size diameters ranging from $\sim 4 \mu \mathrm{m}$ to $\sim 11 \mu \mathrm{m}$ (Fig. 34). Median particle size is higher, however, during glacial periods (MIS 2, 4 and 6) and lowest during interglacial periods (MIS 1, 3, 5, 7), suggesting increased wind strength during glacial periods. Moreno et al. (2002) interpret $\mathrm{Si}$ abundance to represent mostly coarse-grained aeolian quartz, derived dominantly (though not solely) from northeast trade wind-transported aeolian particles from Africa. The flux of relatively coarse-grained quartz dust is highest during glacial periods MIS 2, 4, and 6. Greater flux of fine-grained aluminosilicates, likely clay minerals, as well as Fe-oxides, are also higher during glacial periods, as shown by higher abundances of both $\mathrm{Al}$ and Fe. Moreno et al. (2002) interpret the greater abundances of Fe to represent dust derivation from highly weathered soils in the Sahel region, an interpretation also made by Muhs et al. (2010) on the basis of soils on the Canary Islands.

DeMenocal et al. (1993) present an even longer record of dust deposition from Africa to the eastern equatorial Atlantic Ocean. These workers studied sediments in a core from Ocean Drilling Program Site 663 (S1¹1.9'; W11 ${ }^{\circ} 52.7^{\prime}$; see Fig. 9). Oxygen isotope stratigraphy in the core from this site indicates a record that goes back to almost $900 \mathrm{ka}$, the most recent $500 \mathrm{ka}$ of which are shown in Fig. 35. Biogenic carbonate is the dominant component in the core, as is the case with many marine sediment cores, but the sediments at Site 663 also contain opal, phytoliths, freshwater dia-

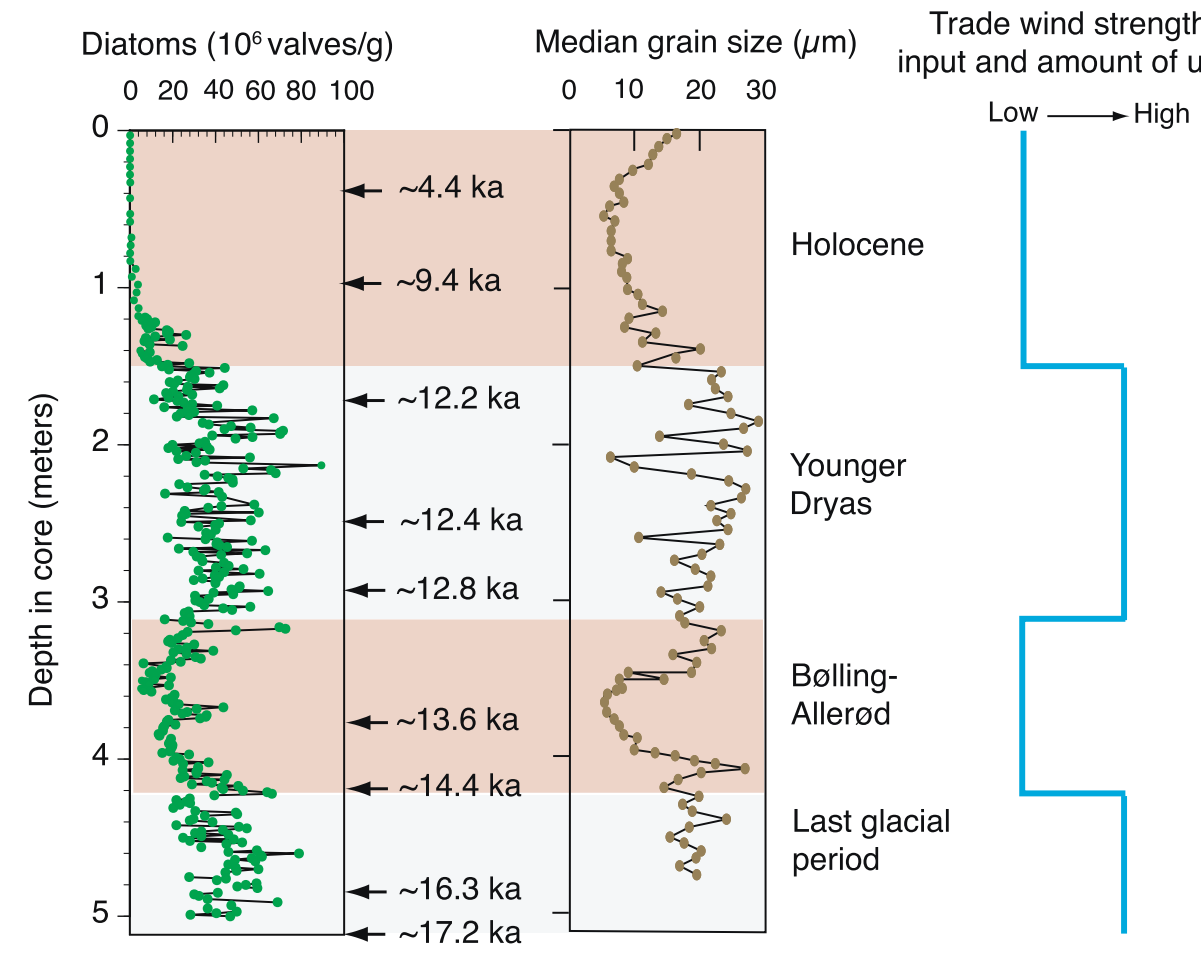

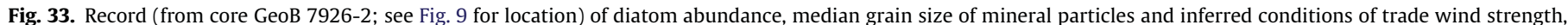

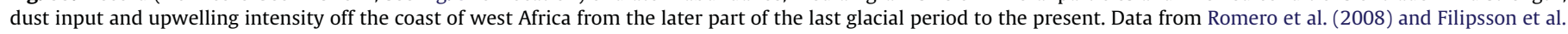
(2011). 


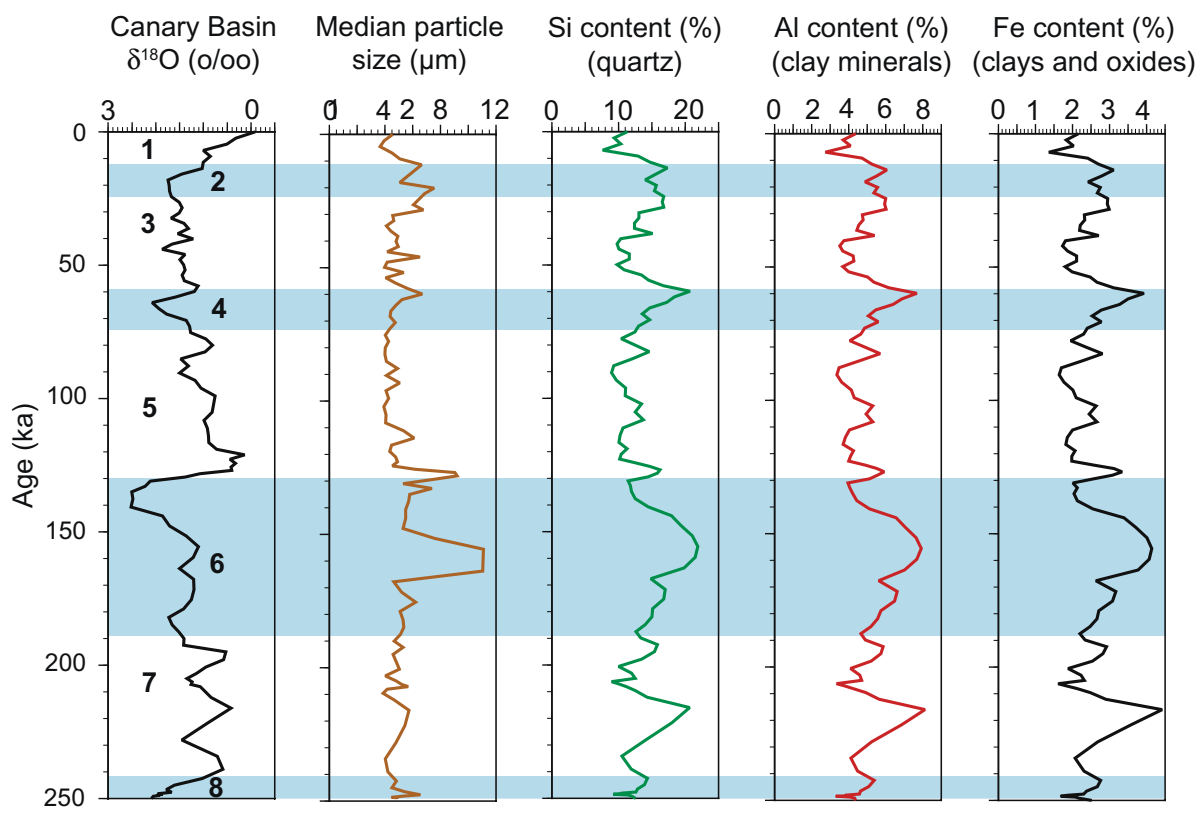

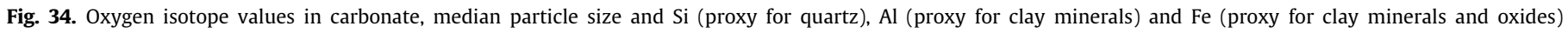

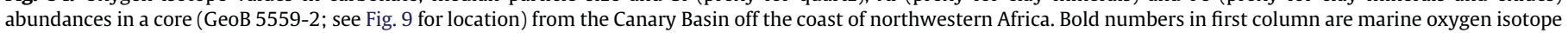
stages; blue shades correspond to glacial periods. All data from Moreno et al. $(2001,2002)$.

toms (Melosira), and terrigenous particles that are interpreted to be aeolian. Because it is situated south of the West African coast, aeolian input to Site 663 comes largely from Saharan and Sahel sources during the winter, from the southward migration of the trade winds and the associated Harmattan winds (Fig. 9). The sediment core record at Site 663 shows that aeolian input to the eastern equatorial Atlantic Ocean occurs during both glacial and interglacial periods (Fig. 35). Nevertheless, the times when the aeolian component is greatest correspond to glacial periods, MIS 2, 4, $6,8,10$, and 12 . The freshwater diatom record follows the same general pattern, with maxima during glacial periods. The sources of the diatoms are interpreted to be dry lakebeds in the Sahara and Sahel regions of Africa. A likely candidate for at least some of these diatoms could be the Bodélé depression in Chad, where aeolian erosion of diatom-rich lakebeds has been well documented (Bristow et al., 2009). DeMenocal et al. (1993) infer that the aeolian record at Site 663 reflects both low-latitude precessional forcing, that modulates the African monsoon, and high-latitude insolation. High-latitude insolation forcing affects North Atlantic sea surface temperatures. Thus, during glacial times, sea surface temperatures are lower and this is inferred to enhance African aridity and wind speed. The interpretation is that during glacial times, source areas are expanded and wind speeds are increased, both of which contribute to the higher terrigenous and diatom contents in the core record. Ruddiman (1997), however, has suggested that three factors related to wind are probably the best explanations for the enhanced flux of dust to the eastern equatorial Atlantic Ocean during glacial periods: (1) movement southward, by several degrees of latitude, of the main dust-transporting winds; (2) an increase in the velocities of southward-moving dust-transporting winds; and (3) an increase in the vertical, lifting power of the storm-related winds that are lifting dust in the source areas. Ruddiman (1997) concludes that glacial-age aridity was of secondary importance to the increased fluxes of dust out of Africa to the eastern equatorial Pacific Ocean.

Very high-resolution studies of marine cores off Africa show that there is variation superimposed on the overall trend of high aeolian flux during glacial periods and low aeolian flux during interglacial periods. DeMenocal et al. (2000) studied a core off the coast of Mauritania (Fig. 9) that spans most of the past $\sim 25 \mathrm{ka}$. They report that dust flux is high during the last glacial period, $\sim 25-17 \mathrm{ka}$, but diminishes abruptly at $\sim 15 \mathrm{ka}$ and does not increase again until $\sim 5 \mathrm{ka}$, with a short period of increased dust flux during the Younger Dryas episode (Fig. 36). They interpret the decreased dust flux from $\sim 15$ to 5 ka to reflect what has been called the African Humid Period. Although the Sahara is now hyperarid, and apparently was so during the LGM, it was considerably wetter during the latest glacial and early Holocene, based on pollen evidence (COHMAP Members, 1988). The period of higher precipitation during the African Humid Period was due to greater summer insolation in the Northern Hemisphere as the last glacial period was ending. Higher summer insolation, which brought about the close of the last glacial period, also brought about an enhanced African monsoon. The higher precipitation and increased vegetation cover in parts of the Sahara and Sahel regions of Africa would have diminished dust supplies, resulting in a lower flux of dust offshore. Similar results showing effects of the African Humid Period on diminished dust flux to the eastern Atlantic Ocean have been seen in cores off Senegal (Mulitza et al., 2008) and Mauritania (Tjallingii et al., 2008).

The African Humid Period also brought about a shift in the mode of particle delivery to the eastern Mediterranean Sea, based on study of a marine core off the coast of Israel (Fig. 14a; Hamann et al., 2008, 2009). During the last glacial period, the main sediment input to the eastern Mediterranean Sea was dust from the Sahara, based on both particle size and clay mineralogical data (Fig. 37). Saharan dust that reaches the eastern Mediterranean Sea is rich in illite and contains much less smectite. The core shows abundant illite during the LGM and particle size modes of $\sim 40 \mu \mathrm{m}$, interpreted to be dominantly aeolian. With the advent of the African Humid Period at $\sim 15 \mathrm{ka}$, the most important sediment input to the eastern Mediterranean Sea became the Nile River, with greatly reduced aeolian inputs. This is reflected in the finer grain size (interpreted to be fluvial) and abundance of smectite, which is found in the Nile River drainage basin. 

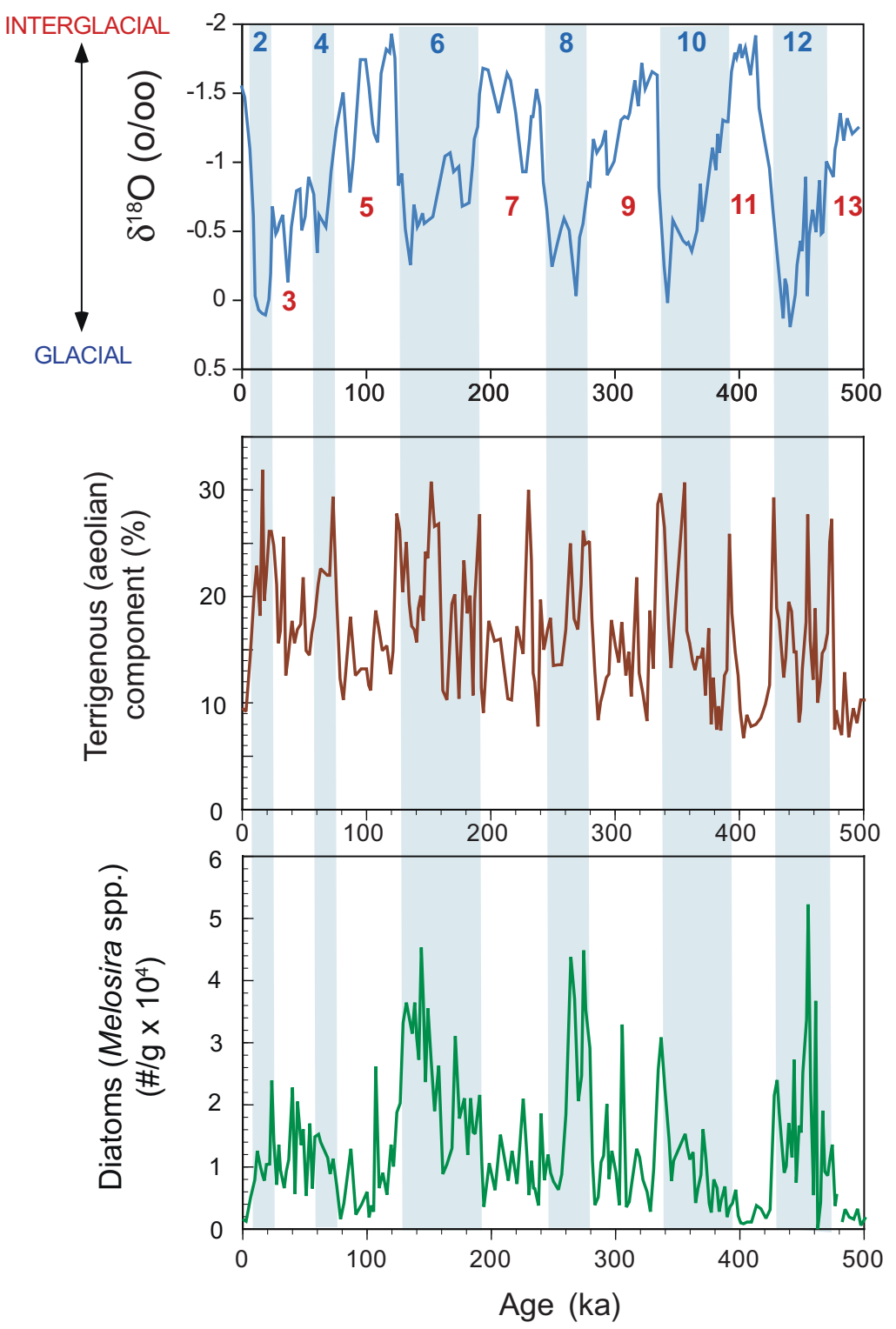

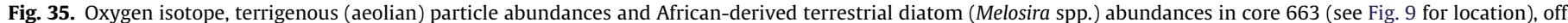
the coast of West Africa. All data from DeMenocal et al. (1993).

\subsection{Marine sediment records of dust in the Pacific Ocean}

Much of our knowledge about the marine sediment records of dust deposition in the Pacific Ocean is due to years of careful study by D.K. Rea and his students and colleagues (see reviews by Rea, 1994, 2007). Rea and co-workers have used many of the same approaches to studying aeolian particles in the Pacific Ocean that have been applied to those in the Atlantic Ocean. Pacific Ocean records of sediment deposition, like those of the Atlantic Ocean, can be complicated with regard to provenance. One factor that is important to consider in Pacific Ocean marine sediment studies is that this basin receives regular inputs of ash from the many active volcanic centers than rim the Pacific. Thus, investigators of marine sediment records in the Pacific Ocean must interpret the non-carbonate components of cores with care, as volcanic ash can be a significant component. Olivarez et al. (1991) show how use of key trace elements (Sc-Th-La) can be effective in distinguishing between continentally derived aeolian particles and volcanic ash. Another factor that applies to the Pacific Ocean is that aeolian sources, largely in Asia (Fig. 8) are much farther from the ocean and occupy a more limited area and latitudinal extent than the African sources that supply dust to the Atlantic Ocean and Mediterranean Sea. Thus, rates of aeolian particle flux are somewhat lower, although of the same order of magnitude. Nevertheless, as pointed out by Rea (2007), Asia is the most important source of dust to the North Pacific Ocean basin, from the mid-latitudes to the tropics. North America supplies very little dust to the North Pacific Ocean, except along the California and Baja California margins (Muhs et al., 2007b, 2008c) and along the southern coast of Alaska (Crusius et al., 2011). Dust input to the Pacific Ocean from Asia is, as discussed earlier, a highly seasonal phenomenon that is a function of the change in the strength of the East Asian monsoon (Fig. 10). The transport of dust from Asia is easily seen at present on MODIS imagery, with dust transported thousands of kilometers to the east, to Korea, Japan and the Pacific Ocean (Fig. 24).

The formation of dust source areas in Asia took place over millions of years. Rea et al. (1998) studied a core in the north-central Pacific Ocean that contains a record of aeolian dust flux that goes 

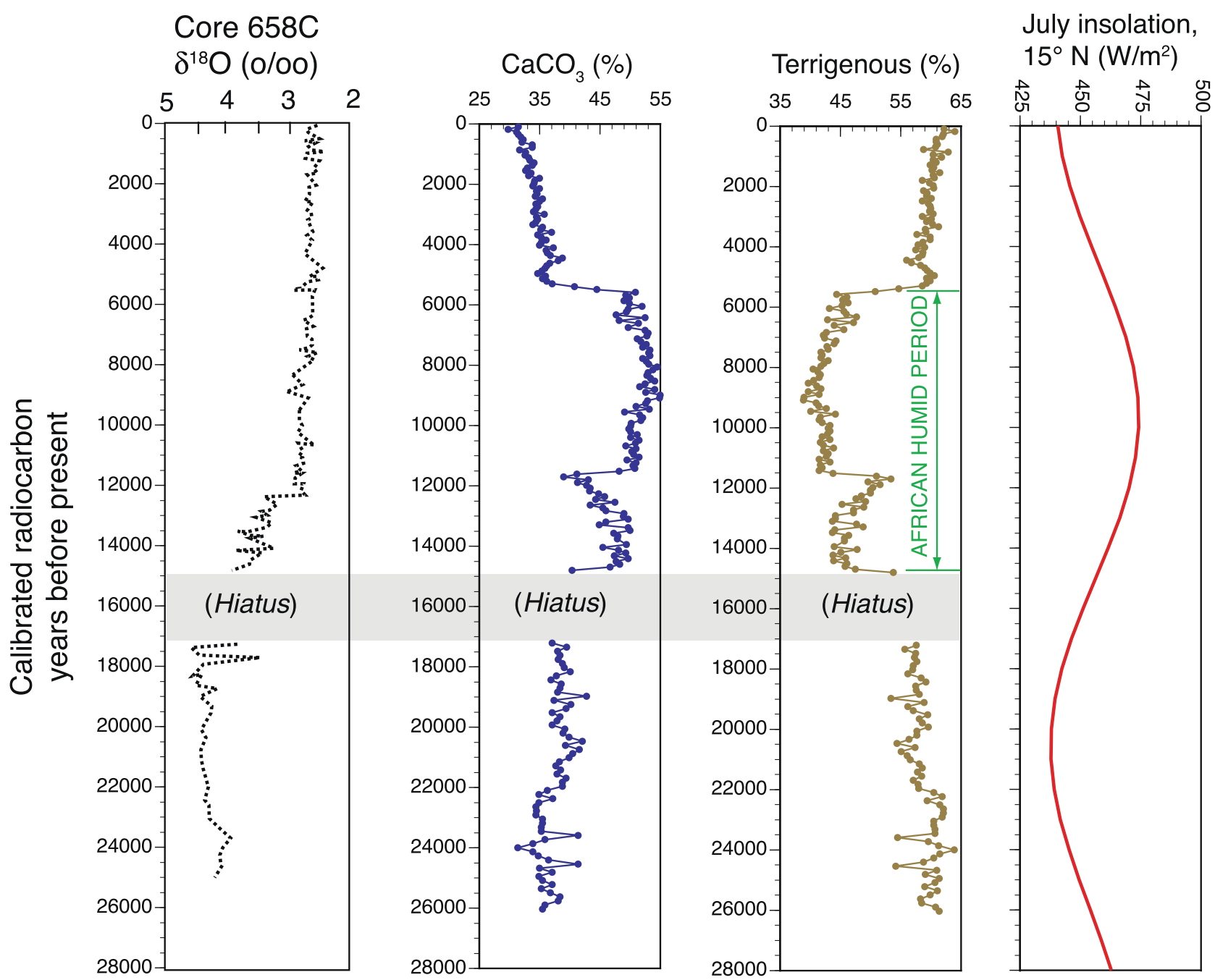

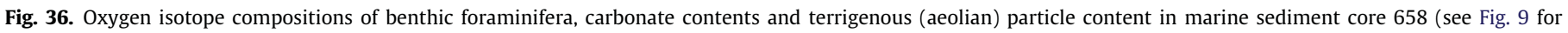

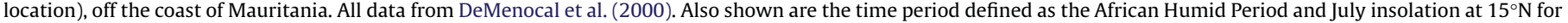
the past $\sim 28 \mathrm{ka}$ (data from Berger and Loutre (1991)).

back $\sim 12 \mathrm{Ma}$. They show that changes in the flux of dust to the Pacific Ocean are due to a complex series of climatic and tectonic events that span much of the late Cenozoic. A crucial part of the story for the Quaternary is that many of the presently arid basins of Asia were much more humid in the Miocene and Pliocene. Tectonic uplift of the northern Tibetan Plateau in the Pliocene, around 3.6 Ma, blocked the monsoonal flow of moisture from the Indian Ocean and created greatly expanded source areas that increased the flux of dust to the Pacific Ocean. Dust fluxes to the north-central Pacific Ocean rose by an order of magnitude after $\sim 3.6 \mathrm{Ma}$ (Rea et al., 1998). This change is also seen in the record of loess deposition on the Chinese Loess Plateau, as discussed earlier (Fig. 21).

During the Quaternary, there has been variation in the flux of dust to the North Pacific Ocean on glacial-interglacial timescales, just as is the case in the Atlantic Ocean. One of the best-studied cores is $\mathrm{V} 21-146\left(\mathrm{~N} 37^{\circ} 41^{\prime}\right.$; E163 $\left.02^{\prime}\right)$, raised from a locality east of Japan and $\sim 3500 \mathrm{~km}$ east of dust sources in China. Hovan et al. (1991) present an aeolian dust record that spans the past $\sim 500$ ka (Fig. 38). Median particle size is, as expected at such a distal location, very fine and ranges mostly between $\sim 4 \mu \mathrm{m}$ and $\sim 8 \mu \mathrm{m}$. Dust input is greater during glacial periods, as is the case in marine cores in the Atlantic Ocean. Hovan et al. (1991) consider that dust flux is primarily a measure of aridity in the dust source areas in Asia. They correlate the periods of maximum dust flux in the Pacific Ocean with the major periods of loess deposition in China. Interestingly, dust flux is generally higher in younger glacial periods than older glacial periods. Hovan et al. (1991) speculate that ongoing uplift of the Tibetan Plateau through the Quaternary may have continued to expand dust source areas in Asia through increasingly greater blockage of moisture sources from the Indian Ocean. Median grain size is considered by Hovan et al. (1991) to be primarily a measure of wind strength. It is interesting, therefore, that the coarsest grain sizes are found primarily during interglacial periods rather than glacial periods. Two explanations are offered for this observation, including weaker winds during glacial times, or a volcanic component that is coarser grained and that dominates the signal during interglacials. The latter explanation seems more likely, as Hovan et al. (1991) point out that if one assumes a more-or-less constant rain of volcanic particles over a Quaternary timescale, then during interglacial periods, when dust flux is lower, the coarser volcanic grains will have a greater imprint on the grain size record.

In equatorial regions of the Pacific Ocean, there is no question that marine sediment has an aeolian component, but the record has been much more difficult to interpret than at higher latitudes in the North Pacific Ocean. Chuey et al. (1987) and Rea (1990) present data from a core raised near the equator at site RC11-210 $\left(\mathrm{N} 1^{\circ} 49^{\prime} ; \mathrm{W} 140^{\circ} 03^{\prime}\right)$. This core contains a record extending to 

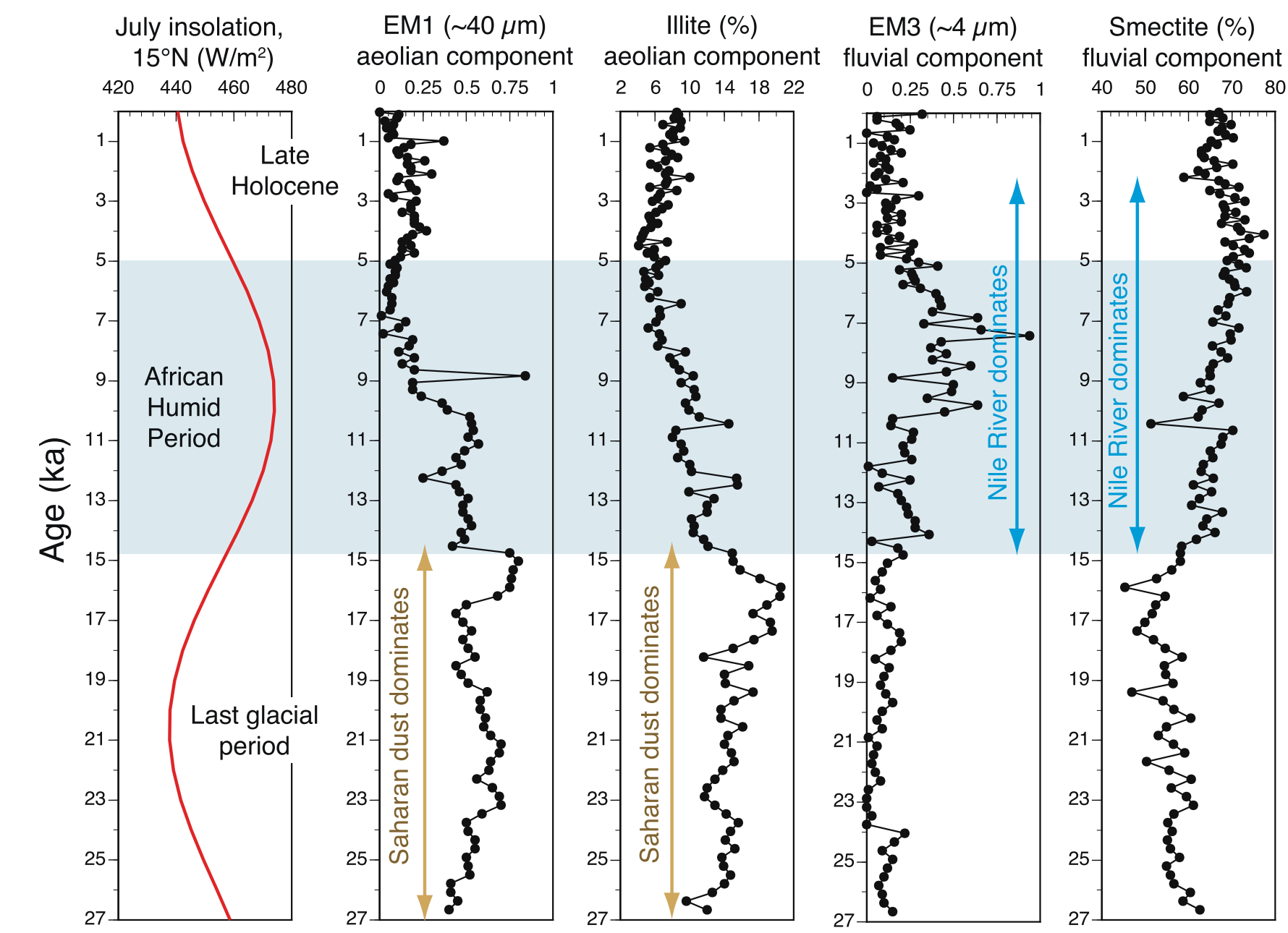

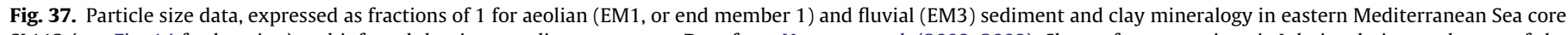

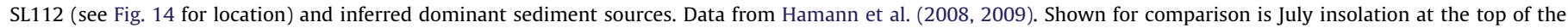
atmosphere at $15^{\circ} \mathrm{N}$ (data from Berger and Loutre (1991)).

950 ka. Compared to cores from the North Pacific Ocean, the proportion of an aeolian component in this core is much lower, aeolian particles are finer grained, and overall aeolian flux is much lower. Part of the problem in interpreting the marine aeolian record of the central equatorial Pacific Ocean is that it is much more difficult to link the dust particles to a specific source. Chuey et al. (1987) speculate that dust in this part of the Pacific Ocean could be derived from Asian, Australian or South American sources. It is also possible that some combination of these sources has contributed dust to the region.

A puzzling issue that arose in early studies is that unlike the record of the North Pacific Ocean, peaks in aeolian flux in the equatorial Pacific Ocean did not seem to show a clear link to glacial periods. Chuey et al. (1987) and Rea (1990) developed a chronology that was based on correlation to the SPECMAP oxygen isotope stratigraphy of Imbrie et al. (1984). They report maximum dust fluxes during glacial periods at some times and during interglacial periods at other times. Anderson et al. (2006) re-dated the sediments in several equatorial Pacific Ocean cores using a ${ }^{230} \mathrm{Th}$ "normalization" technique to correct for sediment focusing. They also used ${ }^{232}$ Th accumulation rates as a proxy for aeolian dust accumulation. Unlike ${ }^{230} \mathrm{Th}$, which is generated primarily by in situ radioactive decay of ${ }^{234} \mathrm{U}$ in the overlying water column, ${ }^{232} \mathrm{Th}$ is a primordial isotope that is found in detrital particles. Thus, ${ }^{232} \mathrm{Th}$ is a reasonable proxy for aeolian particles in a location such as the equatorial Pacific Ocean. Anderson et al. (2006) conclude from these analyses that dust flux rates in the equatorial Pacific Ocean were highest during glacial periods (MIS 2, 4, and 6), consistent with the higher glacial-period dust flux rates in the North Pacific Ocean. A similar approach was taken by Winckler et al. (2008), who extend the equatorial Pacific Ocean record back to $\sim 500 \mathrm{ka}$. They demonstrate that the ${ }^{232}$ Th-dust-proxy shows highest dust fluxes during all glacial periods of the past $\sim 500 \mathrm{ka}$, including MIS 2, 4, 6, 8, 10, and 12 (Fig. 39).

\subsection{Marine sediment records of dust in the Indian Ocean and Tasman Sea}

The northern Indian Ocean, specifically the Arabian Sea, has been studied in detail for aeolian additions to the deep sea. Particle inputs to this region have diverse origins and it is this complexity of sediment provenance that led Prins and Weltje (1999) and Weltje and Prins (2003) to develop models of end-member grain-size distributions. Prins and Weltje (1999) recognize three end-member sources of sediment to the deep sea here, including proximal dust, distal dust, and fluvial mud. Aeolian sediments are supplied by dust transported from the Arabian Peninsula and the Pakistan-Indian deserts, whereas fluvial sediments are supplied, to a great extent, from the Indus River to the northeast. From studies of a number of cores, they conclude that sediments from the western Arabian Sea are mixtures of proximal and distal dust. In contrast, sediments from the northern Arabian Sea are mixtures of 


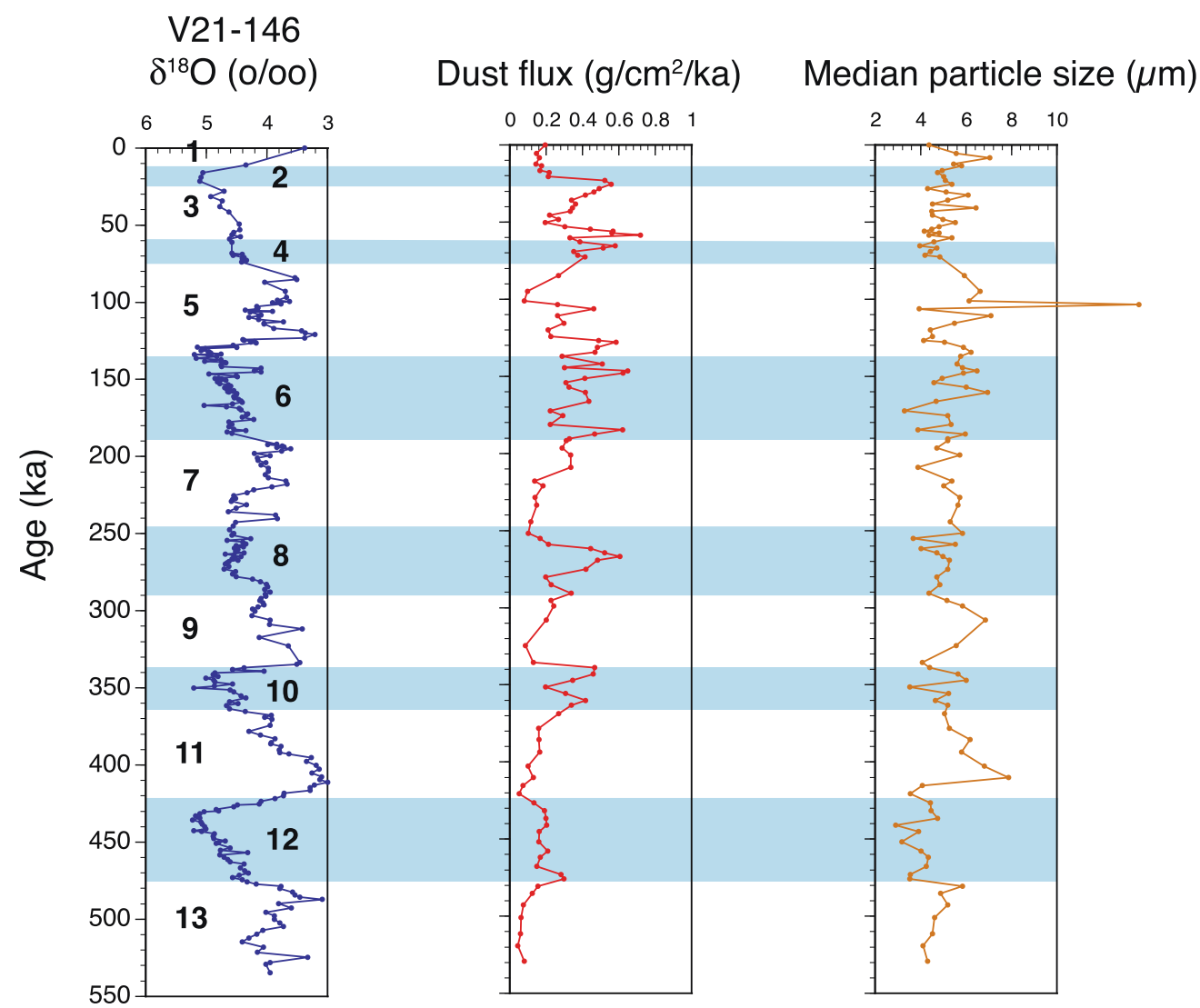

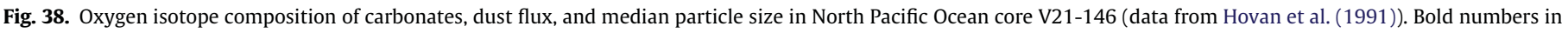
first column are marine oxygen isotope stages; blue shades denote glacial periods.

dust and fluvial mud. In the northern Arabian Sea, the ratio of coarse-grained dust to fine-grained dust is interpreted as a windspeed indicator, with stronger winter monsoons observed during glacial periods. In the same area, the ratio of both aeolian fractions to the fluvial fraction is interpreted as a measure of the degree of continental aridity, which is greater during glacial periods.

Marine sediment cores collected from farther south in the Indian Ocean and in the Tasman Sea show that Australia was an important source of dust during glacial periods of the past $\sim 400 \mathrm{ka}$. As discussed earlier, there is widespread evidence for dust deposition in the southern part of Australia and satellite imagery shows that dust travels off the continent to both the west, into the Indian Ocean, and to the east, into the Tasman Sea (Figs. 8 and 27). Cores collected in both oceans by Hesse (1994) and Hesse and McTainsh (1999, 2003) show that although dust flux is relatively low in both oceans, there are distinct glacial-interglacial differences in dust flux (Fig. 40). Dust fluxes are at a maximum during MIS 2, 4, 6, and 8, similar to what has been found in Northern Hemisphere ocean cores.

\section{Dust deposition in glacial ice}

Dust deposition in the large ice sheets of Greenland and Antarctica provide one of the most dramatic records of LRT aeolian particle deposition. These records are intriguing because the polar locations of these ice sheets, thousands of kilometers away from potential dust source areas, challenge researchers to track dust back to the source. The records are also impressive because they show some of the most pronounced glacial-to-interglacial changes in dust flux that are found in any of the geologic archives discussed herein. Ice cores can be dated by annual layer counting, by cosmo- genic isotopes such as ${ }^{36} \mathrm{Cl}$ and by correlation using the gas record in ice bubbles.

\subsection{Dust records in Antarctic ice cores}

Because of the relatively slow accumulation of ice in Antarctica, some very long records of ice accumulation, oxygen isotopes, deuterium isotopes, carbon dioxide, methane and dust have been acquired from a number of Antarctic ice cores (Fig. 41). Petit et al. (1999) obtained an ice core at Vostok and acquired an 3300-mlong record going back to just over $\sim 400 \mathrm{ka}$, with detailed records of the past five glacial-interglacial cycles. These investigators report that while dust is found in almost all time periods, dust concentrations are many times higher during what deuterium isotopes indicate are glacial periods. The highest dust flux is recorded in the last glacial period, MIS 2.

An even longer record was obtained from the EPICA Dome $C$ core (referred to as EDC; Fig. 41) (EPICA Community Members, 2004). EDC contains one of the most remarkable Quaternary climatic records, with oxygen isotope, deuterium isotope and dust records spanning the past eight glacial-interglacial cycles (Fig. 42). Dust maxima again occur during glacial periods, with glacial dust abundances sometimes two orders of magnitude higher than interglacial dust abundances. The EPICA group also obtained a core from Dronning Maud Land (Fig. 41), on the other side of the continent (EPICA Community Members, 2006). The shorter record of this core goes back to $\sim 150 \mathrm{ka}$, but shows a similar dust record as EDC, over the period of record common to both cores.

Considerable effort has been made in the past decade to ascertain the source of dust in Antarctic ice cores. This is crucial to any paleoclimatic interpretation of Antarctic dust records, because the 


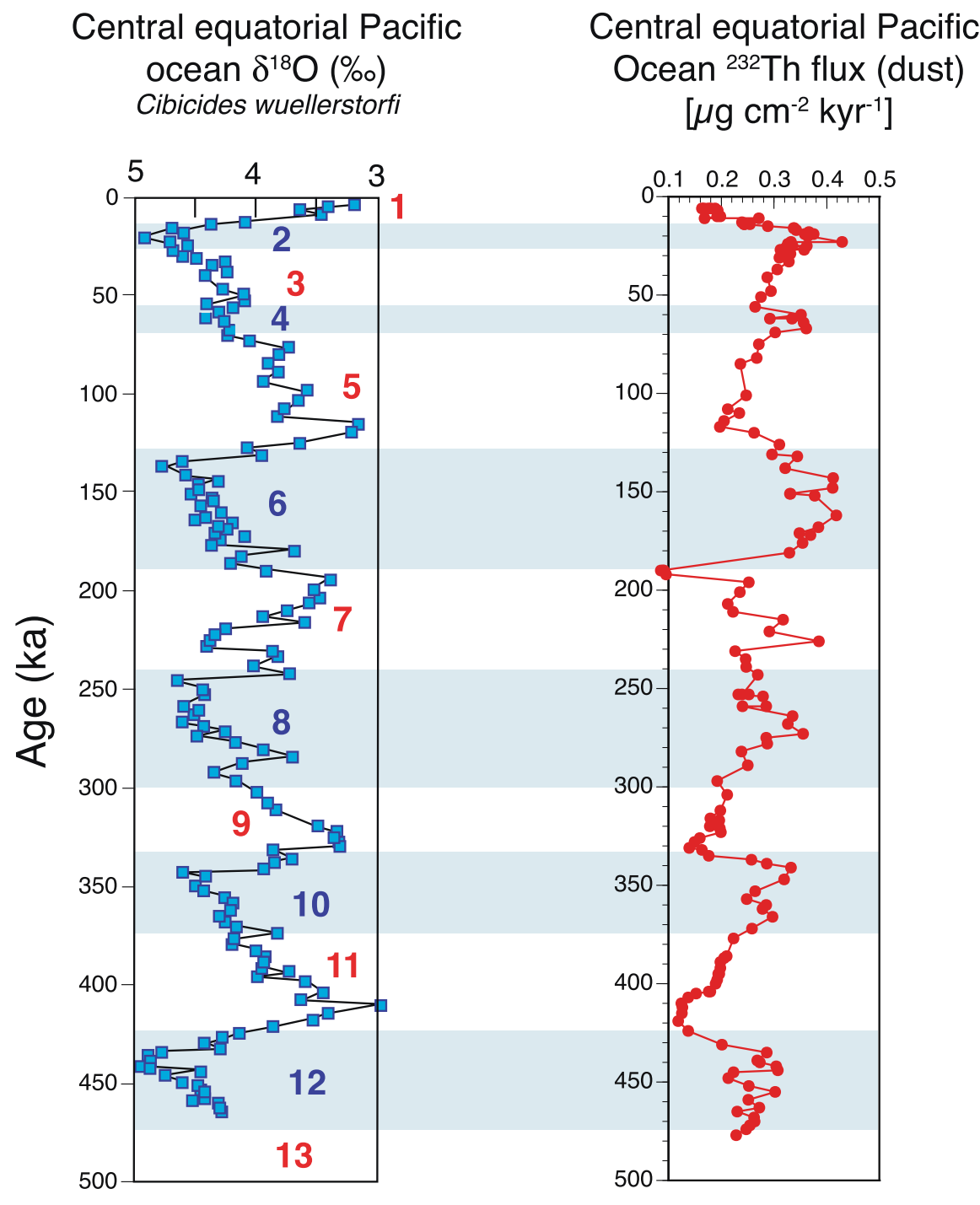

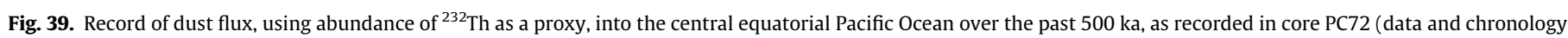
from Winckler et al. (2008)). Shown for comparison is the oxygen isotope composition of benthic foraminifera over the same time period in this core (data from Murray et al.

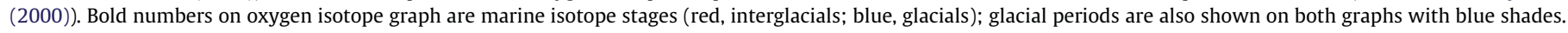

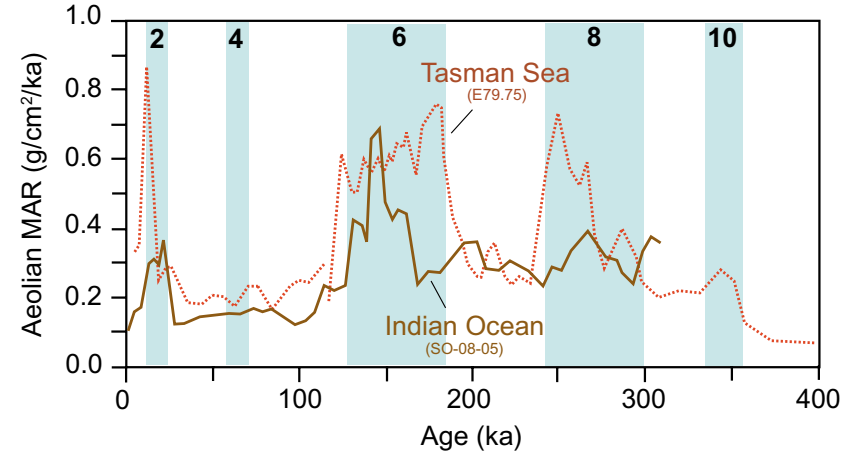

Fig. 40. Aeolian mass accumulation rates (MAR) over the past $\sim 400 \mathrm{ka}$ in cores offshore Australia in the Indian Ocean and Tasman Sea (see Fig. 27a for core locations). Data from Hesse (1994) and Hesse and McTainsh (1999, 2003). Blue shades denote glacial periods.

higher amounts of dust during glacial periods imply greater aridity in the source area or areas, wherever they might be. In a summary of the information at the time, Kohfeld and Harrison (2001) review hypothesized source areas for Antarctic dust in the Southern Hemi- sphere, which include southern South America, Australia, New Zealand and southern Africa (Fig. 41). A series of studies in the past few years, utilizing $\mathrm{Sr}, \mathrm{Nd}$, and $\mathrm{Pb}$ isotopes in dust particles, has narrowed down the possibilities considerably, with some interesting results. Analyses of samples from both EDC and Vostok by Delmonte et al. (2004), using $\mathrm{Sr}$ and Nd isotopes, show that during glacial periods (MIS 2, 4, 6, 8 and 10), dust in both Antarctic cores are similar to each other, indicating a common source. Australia and southern Africa are shown to be unlikely sources, but southern South America, New Zealand and the Dry Valleys of Antarctica itself are all probable sources of dust. Delmonte et al. (2008) did a later study on EDC, with samples from earlier glacial stages (MIS $8,10,12,16$ and 20), again using Sr and Nd isotopes, concluding that southern South America, probably Patagonia, is the most important source, but with perhaps a smaller South American contribution during earlier glacial periods. Using $\mathrm{Pb}$ isotopes, Vallelonga et al. (2010) confirmed that southern South America is the most important source of dust and also verified that there are likely local Antarctic contributions.

An interesting aspect of the detailed $\mathrm{Sr}$ and $\mathrm{Nd}$ isotopic analyses that have been conducted on possible source sediments for dust in Antarctic ice is that there are several possible sources of dust with- 


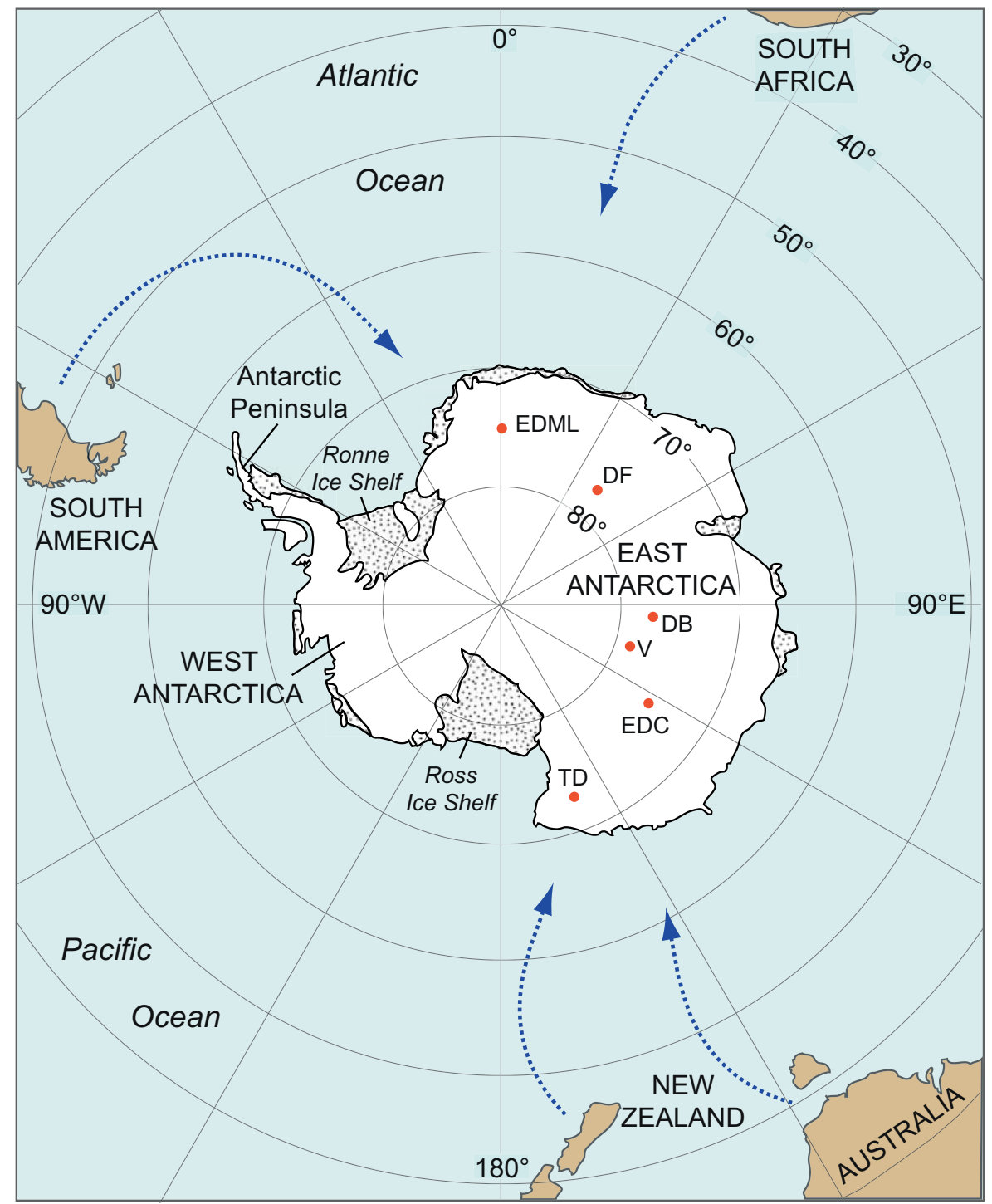

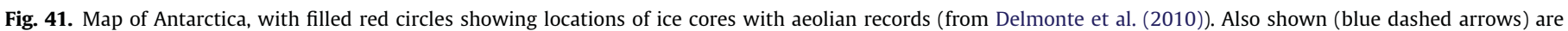

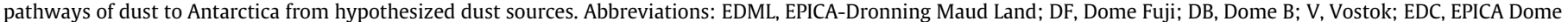
C; TD, Talos Dome.

in southern South America (Fig. 15b), including glaciogenic sources in Patagonia, dust from the high plateaus of Puna and the Altiplano, and loess from the Pampas region of Argentina (Gaiero, 2007). Another possibility permitted by the data is that Pampas loess, deepsea sediments of the Southern Ocean, and Antarctic dust are all derived from the same sources, namely a mixture of Patagonian glaciogenic dust and Puna/Altiplano dust, from farther north (Fig. 15b). Isotopic data from a new Antarctic core from Talos Dome (Fig. 41) support the idea that Antarctic dust could represent a mixture of Patagonian and Puna/Altiplano sources (Delmonte et al., 2010).

Sugden et al. (2009) favor a dominantly Patagonian source for Antarctic dust and provide not only new $\mathrm{Sr}$ and $\mathrm{Nd}$ data, but also an elegant geomorphic model to explain the timing of Antarctic dust maxima. These investigators show that dust maxima in Antarctica, at least those of the past $\sim 100 \mathrm{ka}$, coincide with times of eastward advance of outlet glaciers from the Andean ice cap (Fig. 15b). In their model, dust was generated at times of maximum glacial advance, when broad outwash plains developed to the east of the ice cap, in Patagonia. As outlet glaciers from the ice cap began to retreat, proglacial lakes developed and fine particles became trapped in proglacial lakes. Sugden et al. (2009) show that fine par- ticles from proglacial lake deposits that date to the last glacial period in Patagonia have $\mathrm{Sr}$ and $\mathrm{Nd}$ isotopic compositions very similar to dust particles in Antarctic ice.

Finally, although all investigations have shown that dust maxima in Antarctic ice occurred during glacial periods, there is measurable dust in the parts of these cores that date to interglacial periods. Revel-Rolland et al. (2006) show that glacial-age dust in Antarctica is compositionally distinct from interglacial-age dust in Antarctica. Isotopic studies using $\mathrm{Sr}$ and $\mathrm{Nd}$ by Revel-Rolland et al. (2006) and Pb isotope studies by DeDeckker et al., (2010) suggest that possibility that during interglacial periods, Australia could have been an important dust contributor to Antarctica.

\subsection{Dust records in Greenland ice cores}

A number of ice cores have been taken in Greenland (Fig. 15a) and these records show that dust has been transported to the northern polar region as well as to Antarctica. Unlike Antarctica, however, Greenland's ice dates back only to the latter part of the peak of the last interglacial period (MIS 5.5) at $\sim 120 \mathrm{ka}$, so the record is much shorter. Nearly continuous records have been 


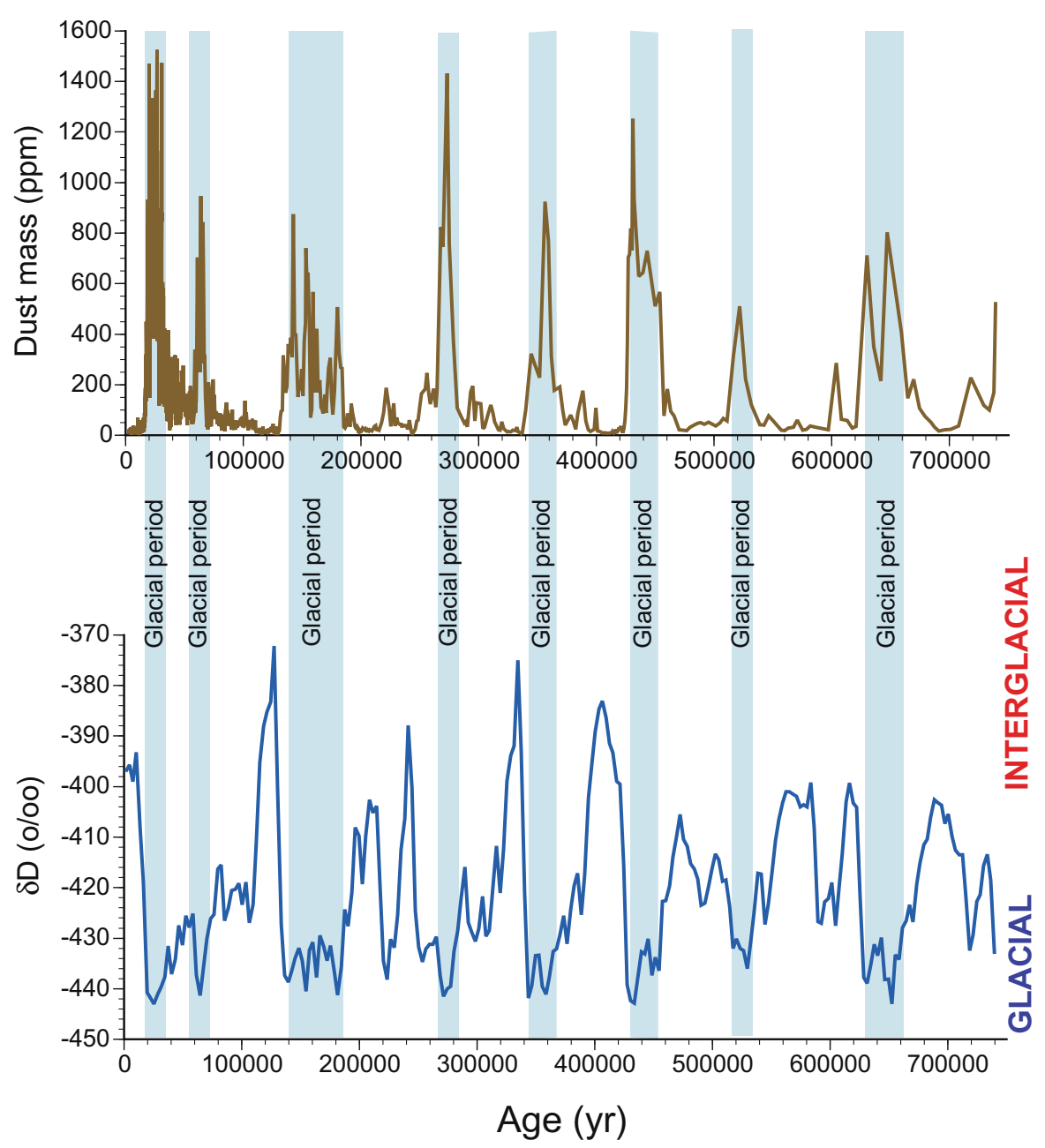

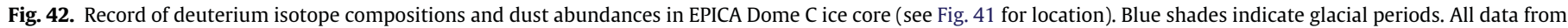
EPICA Community Members (2004).

obtained over much of this interval from two cores, the GISP2 core, studied by Mayewski et al. (1994, 1997) and the NGRIP core, studied by NGRIP Members (2004), Ruth et al. (2007), and Wolff et al. (2010).

Total dust concentrations, as well as chemical data, are reported in the upper part of the GISP2 core, back to $\sim 40$ ka by Mayewski et al. (1994). Concentrations of certain elements measured by these investigators, such as $\mathrm{Ca}$, are considered to be primarily of continental origin (as opposed to a sea salt origin, which is the source of most $\mathrm{Na}$ ). Concentrations of dust and $\mathrm{Ca}$ in GISP2 are highly correlated back to $\sim 40 \mathrm{ka}$. Unfortunately, in the longer (back to $\sim 110 \mathrm{ka}$ ) GISP2 record reported by Mayewski et al. (1997), concentrations of dust are not reported, but Ca data are given for the entire length of the record. Given the close relation of Ca concentrations to dust concentrations in the upper part of the core, Ca is shown as a proxy for dust in the longer record (Fig. 43).

The NGRIP core, studied by NGRIP Members (2004), Ruth et al. (2007), and Wolff et al. (2010), has a dust record that includes much of the same time period as GISP2. Unfortunately, although this record goes from $\sim 123 \mathrm{ka}$ to the present, no dust measurements are apparently available for either the peak of the last interglacial period during the latter part of MIS 5.5 at $\sim 120 \mathrm{ka}$, nor are data available for the Holocene (Fig. 43). Nevertheless, the rest of the core has a very detailed record of dust abundances in Greenland ice that can be compared to GISP2.
Both cores show similar dust abundances over the time periods in common (Fig. 43). The highest dust concentrations are found during the early last glacial period (MIS 4), from $\sim 70 \mathrm{ka}$ to $\sim 60 \mathrm{ka}$, and during the last glacial maximum (MIS 2), from $\sim 25 \mathrm{ka}$ to $\sim 15 \mathrm{ka}$. During relatively warm phases of the last interglacial period (MIS 5), such as MIS 5.3 ( 100-90 ka) and MIS 5.1 ( $\sim 80-75 \mathrm{ka}$ ), and during the Holocene ( $\sim 12-0 \mathrm{ka})$, dust flux is very low. Thus, similar to Antarctic ice cores, Greenland cores show dust maxima during glacials and dust minima during interglacials.

One of the most significant findings of the high-resolution records from Greenland, however, is that these cores also show a detailed record of the nature of dust flux during interstadial periods of the last glacial-interglacial cycle. Both the GISP2 and NGRIP cores have oxygen isotope records that show that climate warmed numerous times in the polar regions of the Northern Hemisphere (Fig. 43). Indeed, the magnitude of these excursions in many cases suggests an amount of warming that is up to one-half that of a full interglacial period, such as the Holocene. Warm interstadial periods were followed by temperature drops to almost full-glacial conditions, indicating rapid excursions between relatively warm and cold episodes over very short timescales. These cycles are now referred to as Dansgaard-Oeschger cycles (or simply D-O cycles), partly after the first investigators who identified them (Dansgaard et al., 1982) in the Dye-3 core in southern Greenland (Fig. 15a). Altogether, 25 such cycles have been identified in the NGRIP core 

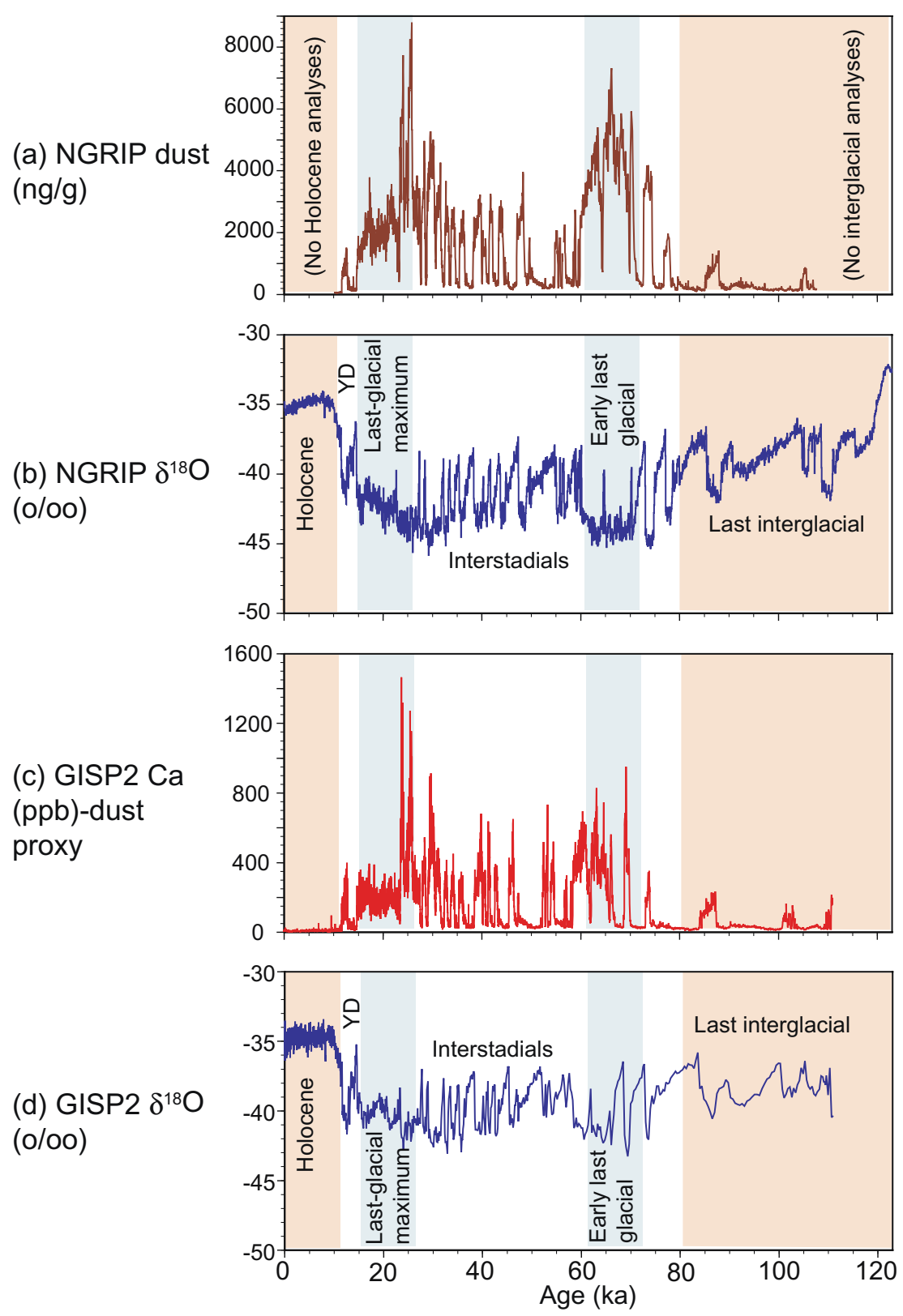

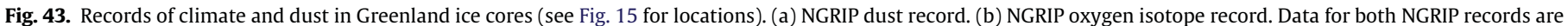

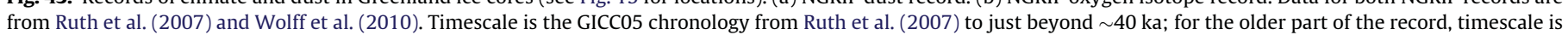

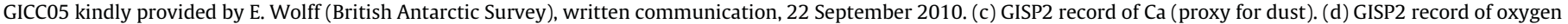
isotopes. GISP2 dust data are from Mayewski et al. (1997); GISP oxygen isotope data are from Grootes et al. (1993).

(NGRIP Members, 2004; Wolff et al., 2010). What is interesting about the Greenland cores is that the rapid excursions in paleoclimate evidenced in the oxygen isotope records of $\mathrm{D}-\mathrm{O}$ cycles are tracked closely by the dust records (Fig. 43). Relatively warm interstadials, with less-negative oxygen isotope values, record times of relatively low dust flux, whereas cold periods have relatively high dust flux. Even the Younger Dryas, a brief ( 13-12 ka) return to very cold conditions after the last glacial maximum, shows a small increase in dust flux in both the GISP2 and NGRIP cores. These observations indicate that the Greenland ice cores contain dust records with a high sensitivity to global climate changes that are linked to the dust source areas.

Compared to Antarctica, much less work has been done on identifying the source of dust in Greenland. Mayewski et al. (1993) hypothesized that areas to the south of the Laurentide ice sheet in North America could be the source of dust in the GISP2 record that they studied. In a later study, they rejected a North American source and, based on climate modeling, suggested the possibility of increased LGM dust transport to Greenland from North Africa, Asia, and areas to the south of the ice sheet in Eurasia (Mayewski et al., 1997).

Biscaye et al. (1997) provided the first empirical study of possible sources of dust for Greenland. They report mineralogy, and $\mathrm{Pb}$, $\mathrm{Sr}$, and Nd-isotopic data for several possible source areas: (1) Gobi Desert sand (3 samples); (2) Chinese loess (3 samples); (3) Ukraine loess ( 1 sample); (4) Alaskan loess (4 samples, all from near Fairbanks); (5) Illinois loess (1 sample); (6) Washington (Palouse) loess (1 sample); and (7) Canadian lake silt (1 sample). They also evaluated Saharan dust as a possible source, from Pb-isotopic compositions of 10 previously analyzed samples. On the basis of 
(a) Modern:

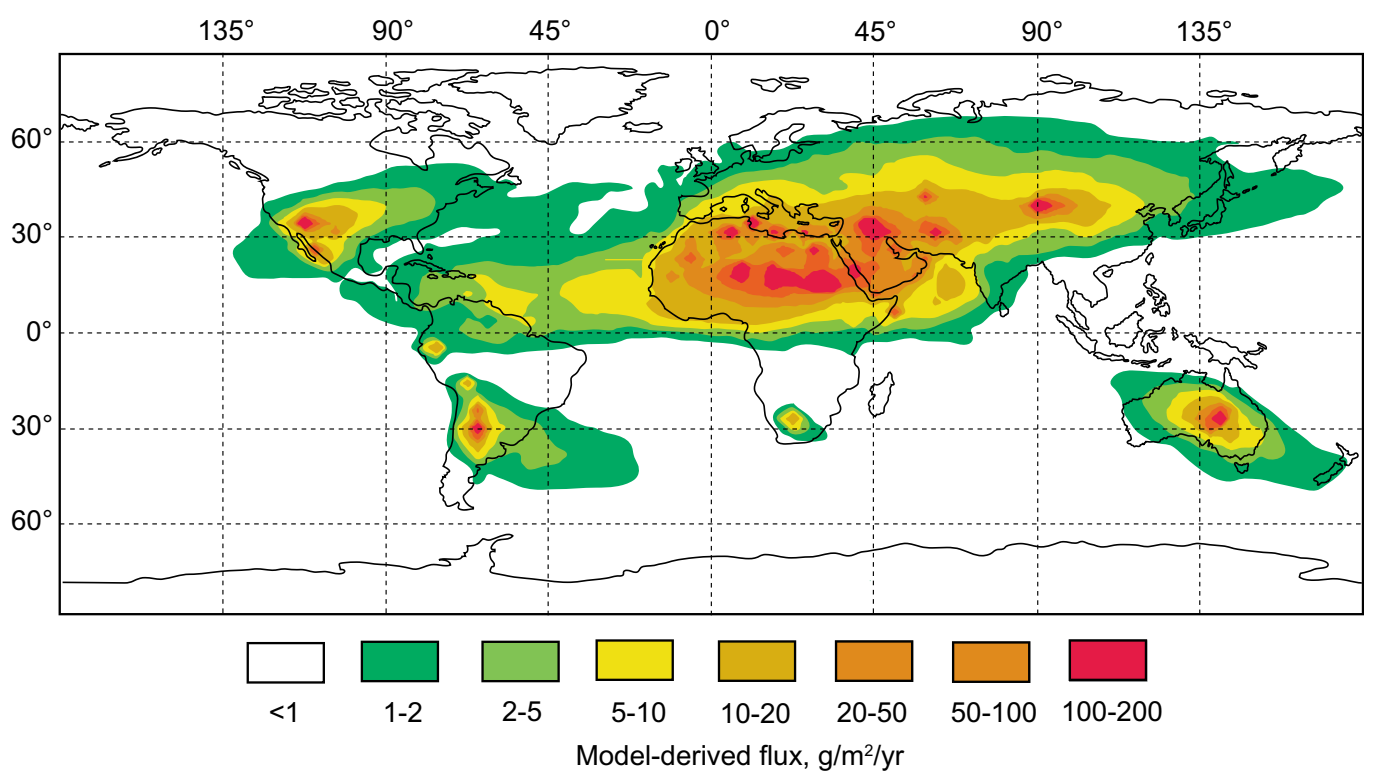

(b) Last-glacial period:

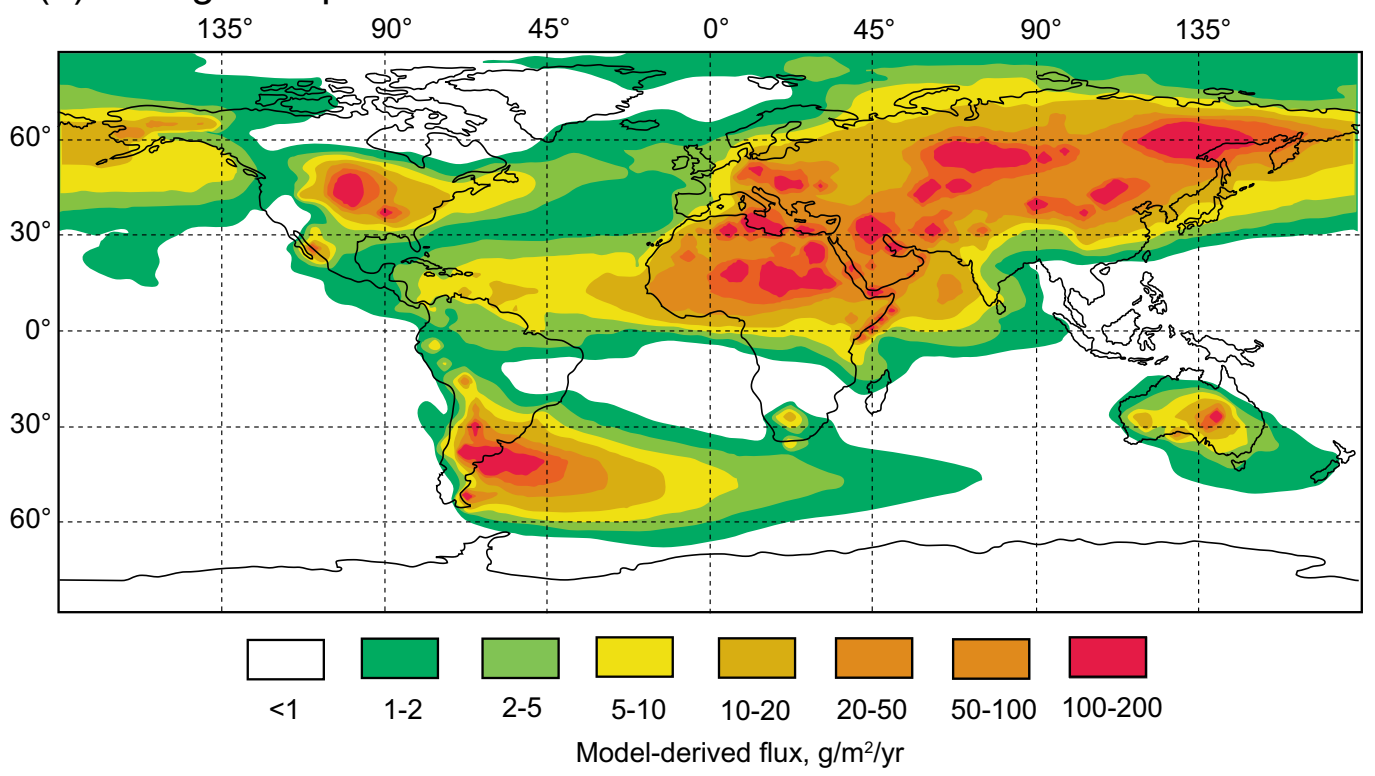

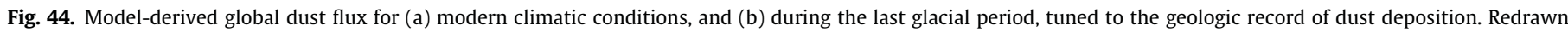
from Mahowald et al. (2006), their Figs. 2 and 10.

compositional similarities between Greenland dust and the Gobi Desert and Chinese loess samples, they conclude that eastern Asia was the main source of Greenland dust during the last glacial period. This study has been cited widely and there seems to have been general acceptance in the ice core dust community that Asia is the primary (and possibly the only) source of dust in Greenland ice. However, it is important to point out that the samples of potential source areas studied by Biscaye et al. (1997) are extremely limited. The entire mid-continental loess belt of North America (Figs. 15a, 16) is represented by one sample, as is the entire Eurasian loess belt south of the Fennoscandian ice sheet (Fig. 13). It has been known for some time that loess sources in the Mississippi River valley changed over time during the last glacial period, depending on which lobes of the Laurentide ice sheet were supplying the drainage system (Frye et al., 1968; McKay, 1979; Grimley et al.,
1998; Grimley, 2000). Because Biscaye et al. (1997) did not specify the depth of their single sample, it is not clear which of these sources it represents and it certainly does not represent all the possibilities in the Mississippi River valley. Second, loess data in the Great Plains region were not reported at all by Biscaye et al. (1997), yet this region has some of the highest loess mass accumulation rates in the world for the last glacial period (Roberts et al., 2003). As shown by Aleinikoff et al. (2008), GISP2 dust samples, studied by Biscaye et al. (1997) have Pb-isotope compositions that are indistinguishable from $\mathrm{Pb}$-isotopic compositions of K-feldpsars in both Great Plains loess and its source sediment, Tertiary volcaniclastic siltstone. Biscaye et al. (1997) did their analyses on polymineralogic samples, so it is not clear if the data are directly comparable, but this needs to be tested. Third, new, higher-resolution OSL ages of the classic Luochuan section on the Chinese Loess 
Plateau by Lu et al. (2007) show that although loess accumulation rates were low during the Holocene, the highest rates occurred not during the LGM, but in the period from $\sim 60 \mathrm{ka}$ to $\sim 25 \mathrm{ka}$, when the $\mathrm{D}-\mathrm{O}$ cycles were being recorded in Greenland ice. During the LGM, from $\sim 25 \mathrm{ka}$ to $\sim 10 \mathrm{ka}$, loess accumulation rates at Luochuan were the lowest of the past $\sim 80 \mathrm{ka}$, other than during the Holocene. If Greenland ice and Chinese loess were being fed by the same Asian dust sources, it is expected that accumulation rates should show the same relative differences between different time periods over the past $\sim 80 \mathrm{ka}$ at the two localities. Finally, in a LGM modeling effort, Mahowald et al. (2006) show that the most likely transport pathways of dust to Greenland would be from the continental US, Alaska, or Siberia (Fig. 44). It certainly seems possible that sources other than Asia could have provided dust to Greenland or at least that multiple sources are involved.

\subsection{Dust in small, high-altitude glaciers}

Small ice caps and valley glaciers exist at high altitudes in many of the world's mountain ranges, even within tropical latitudes. L.G. Thompson and E. Mosely-Thompson of Ohio State University and their co-workers are responsible for generating valuable records of dust flux to high-altitude localities under extremely challenging field conditions, both in South America and Asia. Some of the highest-resolution paleoclimate records of the Americas are ice cores from glaciers in the high Andes of South America. Cores from two glaciers both contain dust records and have very different timing of dust flux maxima. An ice core record from Huascarán, Peru shows a dust flux during the LGM that is about 200 times greater than most Holocene values (Thompson et al., 1995). The timing of this high dust flux is very similar to that found in both the Greenland and Antarctic ice cores. Thompson et al. (1995) interpret the high dust flux in Peru during the LGM to reflect a decrease in humidity, precipitation, and vegetation cover in South America at this time, as well as stronger winds. In contrast, an ice core taken from the summit of Sajama Mountain, Bolivia shows much higher values in the Holocene than during the LGM, which is inconsistent with both the Peruvian record and that of polar ice cores (Thompson et al., 1998). Thompson et al. (1998) interpret the enhanced Holocene dust flux in Bolivia to represent increased volcanic activity, elevated snowlines, and decreased net accumulation since the LGM.

Thompson et al. (1989) also report records of dust flux from higher-latitude ice caps on the Qinghai-Tibetan Plateau in Asia. These records are of particular interest in that they can be compared with the nearby Chinese loess records and the dust flux into Lake Biwa in Japan. From the Dunde ice cap in this region, there is a record that goes back to $\sim 40 \mathrm{ka}$. Thompson et al. (1989) show that, similar to the Chinese Loess Plateau and Lake Biwa, maximum dust flux took place during the last glacial maximum (LGM). Dusty conditions apparently prevailed during the latter part of the last glacial period and then diminished abruptly at $\sim 10 \mathrm{ka}$.

\section{Discussion and concluding thoughts}

In reviewing the geologic records of dust, several observations can be made. One is that dust can be found in a wide variety of archives, including loess, lake sediments, soils, marine sediments, and glacial ice. With the advent of TOMS and MODIS imagery from satellites, it is now possible to ascertain what regions are the most important sources of dust and their general transport directions, at least at present. From these source areas, those sources that existed in the past, and the widely distributed archives of dust deposition, it is clear that dust can reach almost any part of the globe. Particles become finer and less abundant farther away from sources, but clear records of dust flux are found from the equator to the poles, on every continent and in every ocean basin.
What is apparent in the loess, lake sediment, marine sediment, and ice core data (and even can be inferred from soils data, in places) is that the last glacial period saw a much greater flux of dust than the Holocene. This is a simplified view, of course, as dust flux in some source areas became diminished during or even before the close of the last glacial period (e.g., the African Humid Period, discussed earlier). Nevertheless, the last glacial period at its peak was a dustier period and, where longer records exist, in loess, marine sediment, and Antarctic ice cores, it is apparent that earlier glacials had dustier atmospheres than earlier interglacial periods, too. Thus, it seems to be a general condition of at least the late and midQuaternary that the Earth was a dustier planet during glacial periods.

What could cause this remarkable change in state, where the Earth becomes so dusty during glacial periods? A number of field investigators and climate modelers (Kolla et al., 1979; Petit et al., 1981; COHMAP Members, 1988; Joussaume, 1990, 1993; Yung et al., 1996; Biscaye et al., 1997; Mahowald et al., 1999; Kohfeld and Harrison, 2001) have proposed various mechanisms that may have contributed to ice-age increases in global dustiness: (1) increased wind speeds, so that more dust is entrained and can be transported farther; (2) a decreased intensity of the hydrological cycle, such that dust can remain in suspension longer, with fewer periods of washout, and can therefore be transported farther; (3) decreased soil moisture, such that dust is more easily entrained; (4) decreased precipitation and vegetation cover, which diminishes protection for dust sources and increases dust source areas; and (5) exposed continental shelves, resulting in an expansion of dust source areas. All of these factors likely played important roles in increasing global dust concentrations, although it is often difficult to ascertain which specific factors were most important in each particular area.

One factor that has been overlooked or downplayed in many dust modeling studies for the LGM, at least until recently, is that there was a tremendous increase in the production of glaciogenic fine-grained particles with the growth of the Laurentide, Cordilleran, and Fennoscandian ice sheets, as well as expansion of many small ice caps and valley glaciers at high altitudes and high latitudes in both the Northern and Southern Hemispheres. There is no question that much of the youngest loess that is so extensive over parts of North America, South America, Europe and Asia is the direct result of glaciogenic silt production from expanded continental ice sheets, mountain ice caps, and valley glaciers during the LGM. Early efforts to model the high dust flux during the LGM were unable to capture the high dust concentrations in polar ice caps (Joussaume, 1990, 1993; Genthon, 1992). A later model by Andersen et al. (1998) captured more of the observed LGM dust record by adding decreased soil moisture as a factor, but still did not produce as much dust as observed in the geologic record. Modeling by Mahowald et al. (1999) explained additional LGM dustiness by adding in decreased vegetation cover as a factor. However, none of these modeling efforts incorporated the effect of increased finegrained particle availability from expanded ice sheets or valley glaciers. Mahowald et al. (2006) generated a new series of global dust models, where an atmospheric general circulation model (CCSM3) was linked to a biogeography model (BIOME3). Consistent with previous results, LGM dust fluxes are much greater than modern fluxes, based on previous considerations of expanded source areas due to decreased vegetation cover, decreased soil moisture, increased aridity, and a decreased intensity of the hydrologic cycle (see Fig. 8a of Mahowald et al., 2006). In addition however, dust sources were added in from glaciogenic sources, taken from loess localities where sufficient geologic data (thickness, chronology, particle size) existed to compute mass accumulation rates. In making the flux calculations, care was taken to include only the very fine-grained component of the loess $(<10 \mu \mathrm{m})$, i.e., those particles 


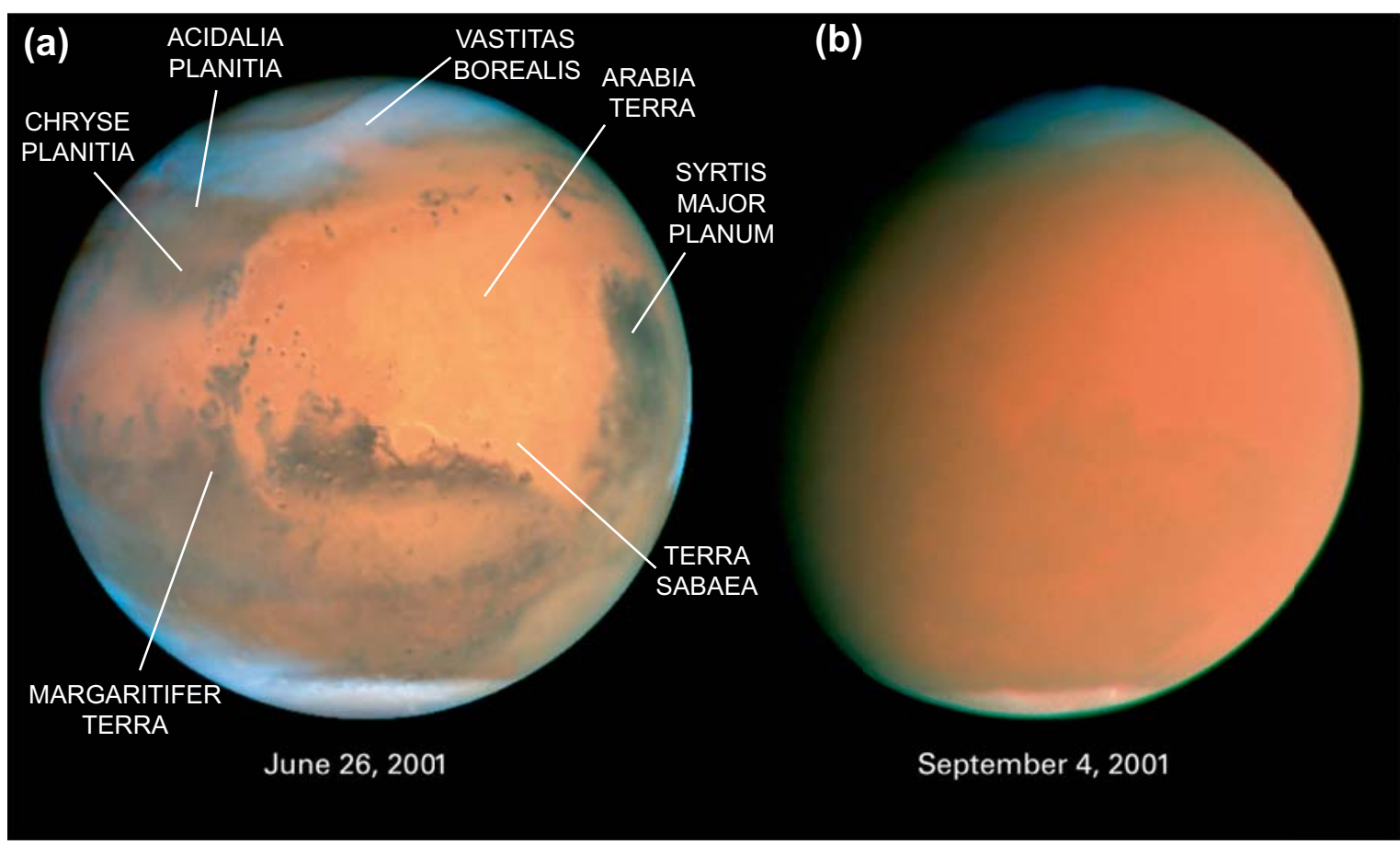

(c)

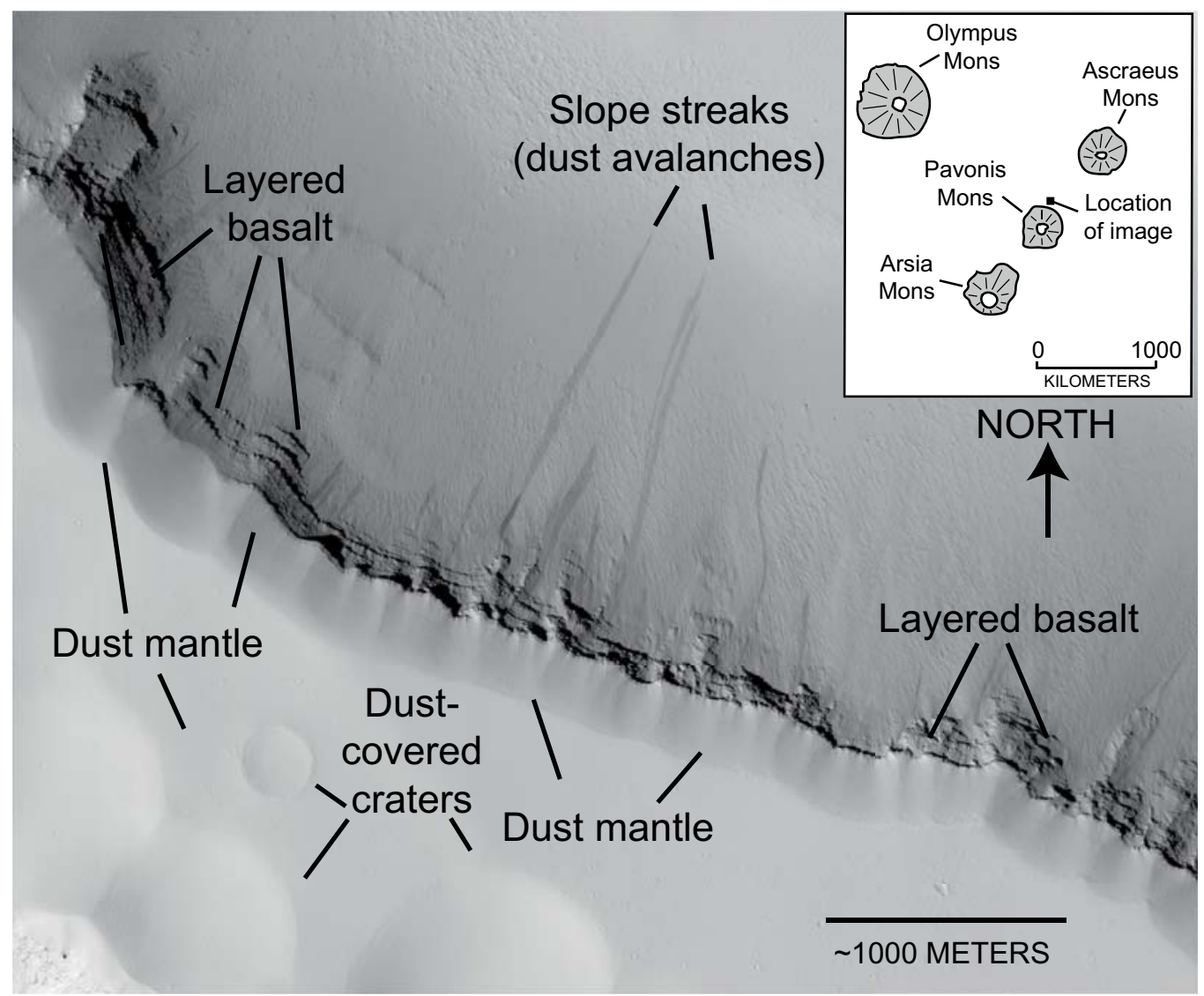

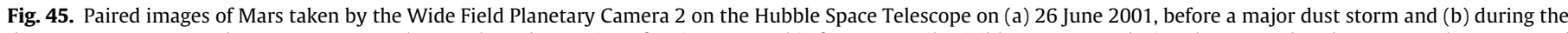

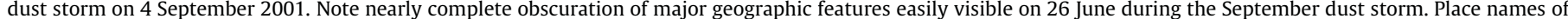

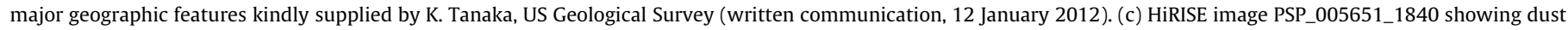
mantle over basalt on the northern flank of Pavonis Mons. Image courtesy of NASA/JPL/University of Arizona.

that could contribute to LRT dust flux, rather than using bulk loess. The result of this modeling effort shows an LGM world with significantly higher fluxes of dust globally, with many sources derived from glacial ice that do not appear on either the modern dust flux map (Fig. 44), or on the LGM map that does not consider glacial sources (see Mahowald et al., 2006, their Fig. 8a). When LGM glacial sources are included, expanded source areas of dust appear in central North America, Alaska, Europe, and Siberia (Fig. 44). 
Furthermore, dust flux from glacial sources in southern South America are expanded, both in terms of spatial extent and modeled distance of offshore transport. This latter finding is consistent with the model of the Patagonian LGM "dust machine" presented by Sugden et al. (2009). Thus, it seems likely that the dustier LGM world was due to a combination of both climatic and geologic factors, with the latter being dominated by greatly increased glaciogenic dust production.

The picture of an LGM world that is characterized as colder, drier, less vegetated and far dustier has interesting implications for a variety of climatic and paleoclimatic considerations. Greater dust flux in the atmosphere would have had significant effects on the planetary radiation balance. Over oceans and other dark surfaces, albedo would have increased, with a decrease (compared to an interglacial period) in the amount of incoming solar radiation. Over land, and particularly over highly reflective surfaces such as desert regions, snow-covered landscapes, or ice sheets, reflection of incoming solar radiation would actually have decreased, with a potential warming effect, a concept that has been modeled by Overpeck et al. (1996) and proposed for some regional warming (Roberts et al., 2003). Because of the greater surface area of the oceans compared to land, it is likely that the increased LGM dust flux had a net cooling effect, although warming could have been important regionally.

Another important effect of greater LGM dust flux would have been fertilization of marine organisms, particularly primary producers such as marine phytoplankton (Martin, 1990). Because such organisms are often Fe-limited, delivery of Fe-rich dust to the world's oceans would have enhanced phytoplankton growth, with perhaps a greater frequency of phytoplankton "blooms" such as those that can be observed at present when dust is carried to the ocean (Figs. 2 and 30). The importance of increased phytoplankton growth is that because these organisms photosynthesize, increased growth would also result in carbon dioxide drawdown in the atmosphere. Indeed, Falkowski et al. (1998) estimate that increased phytoplankton production during glacial periods due to dust could have lowered atmospheric $\mathrm{CO}_{2}$ concentrations from $\sim 275 \mathrm{ppm}$ to $\sim 245$ ppm, approximately $30 \%$ of the full, pre-industrial interglacial-glacial difference in atmospheric $\mathrm{CO}_{2}$ content.

Dust delivery to some regions on land could have also enhanced soil fertility. This effect would be most significant in those areas where pre-existing soils had minimal fertility. Lack of soil fertility could result from either of two climatic extremes and their effects on pedogenesis. One extreme is that of thick, well-developed, but extremely low-nutrient-status soils (Ultisols and Oxisols), such as those found in the humid tropics. For example, Swap et al. (1992) suggest that the productivity of the Amazon rain forest is dependent on nutrients delivered to the region from African dust. Koren et al. (2006) even ventured the idea that fully half of the dust reaching the Amazon rain forest comes from a single source in Afri$\mathrm{ca}$, the Bodélé depression. As alluded to earlier, this hypothesis needs far more testing, but studies by Muhs et al. (2007a) have shown that on islands near South America, such as Barbados, soil development has been influenced strongly by African dust inputs for much of the Quaternary. The contrasting environment where dust inputs could be important for soil fertility is in high-latitude or high-altitude environments, where cold temperatures and sometimes little moisture availability inhibit rock or sediment weathering, clay production, and nutrient release. Fine-grained inputs to otherwise minimally developed soils in cold climates can thus give soils a nutrient-holding capacity as well as a favorable nutrient status that they otherwise might not have.

Our current understanding of the difference in planetary dustiness on the Earth during interglacial and glacial periods has applications to other planets as well. Dust is common on Mars, with particle size diameters estimated to be $\sim 2 \mu \mathrm{m}$ to $\sim 5 \mu \mathrm{m}$, similar to LRT dust found on Earth (Kahn et al. 1992; Lemmon et al. 2004). Most dust on Mars is thought to have been produced by ancient volcanic, impact and fluvial processes, with perhaps some smaller contributions from glacial grinding (Bridges and Muhs, 2012). Most Martian dust particles generated by these processes likely were produced before $\sim 3.5$ to $\sim 1.8 \mathrm{Ga}$ (Tanaka et al., 1992). Although there may be little dust particle production now, dust storms do occur on Mars and can be spectacular. Dust storms that encircle the entire planet have been observed to occur on average about one out of every three Martian years (Zurek and Martin, 1993). A good example is the dust storm observed through the Hubble telescope during the summer of 2001 (Strausberg et al., 2005). Although it began as a series of smaller dust storms, through time this developed into a significant mass of dust that enveloped much of the planet (Fig. 45a and b).

There is increasing evidence that there are abundant geologic records of dust on Mars (Bridges et al., 2010). Bridges and Muhs (2012) point out that loess is becoming an appropriate analog for Martian "duststone" deposits (Fig. 45c). Such deposits can be quite thick and Bridges and Muhs (2012) speculate that duststone accumulation may actually be one of the major rock-forming processes today. Unlike terrestrial loess, however, which is stabilized primarily by increasing precipitation (which washes dust out of the atmosphere), vegetation colonization (which stabilizes deposited sediment) and removal of supply, Martian dust accumulation requires aggregation, cementation and burial, processes that do not necessarily require liquid water. Nevertheless, as pointed out by Bridges and Muhs (2012), during glacial times, when winds may have been stronger, many regions were more arid, vegetation cover was reduced, the hydrologic cycle was less intense, and dust supplies were greater, the Earth was more like Mars and was a dustier planet overall.

\section{Acknowledgments}

This review was inspired by a special session on dust organized by Art Bettis (University of Iowa), held at the 2010 annual meeting of the American Association for the Advancement of Science in San Diego. My work is supported by the Climate and Land Use Change Program of the US Geological Survey and this paper is a contribution to the "Impacts of climate change on coastal and eolian landscapes" project. The paper is also a contribution to the African Humid Period dust project of N. Mahowald (Cornell University), supported by NSF Grant \#1003509. I thank Tim Horscroft, Jeff Lee and Ted Zobeck for inviting me to do this review. Many thanks go to my dust and loess friends who have provided me with many of the thoughts and observations reviewed here. I also thank Eric Wolff (British Antarctic Survey), Ana Moreno (Universitat de Barcelona), and Gisela Winckler (Lamont-Doherty Earth Observatory) who kindly supplied digital files of their dust data from Greenland, the Canary Basin, and the central equatorial Pacific, respectively. Ken Tanaka (USGS, Flagstaff) and Nathan Bridges (Johns Hopkins University) helped me put together the figures for Mars. Thanks go to Josh Preston of Oh Boy Records/Red Pajamas Records/Blue Plate Music for allowing me to use the quote from Steve Goodman's great song. Jan-Berend Stuut (Universität Bremen), Jeff Pigati, Tom Judkins and Gene Ellis (all USGS), and an anonymous reviewer provided helpful comments on an earlier draft of this paper, which I appreciate.

\section{References}

Aleinikoff, J.N., Muhs, D.R., Sauer, R., Fanning, C.M., 1999. Late Quaternary loess in northeastern Colorado, Part II - Pb isotopic evidence for the variability of loess sources. Geological Society of America Bulletin 111, 1876-1883.

Aleinikoff, J.N., Muhs, D.R., Bettis III, E.A., Johnson, W.C., Fanning, C.M., Benton, R., 2008. Isotopic evidence for the diversity of late Quaternary loess in Nebraska: 
glaciogenic and non-glaciogenic sources. Geological Society of America Bulletin 120, 1362-1377.

Andersen, K.K., Armengaud, A., Genthon, C., 1998. Atmospheric dust under glacial and interglacial conditions. Geophysical Research Letters 25, 2281-2284.

Anderson, R.F., Fleisher, M.Q., Lao, Y., 2006. Glacial-interglacial variability in the delivery of dust to the central equatorial Pacific Ocean. Earth and Planetary Science Letters 242, 406-414.

Begét, J.E., Stone, D.B., Hawkins, D.B., 1990. Paleoclimatic forcing of magnetic susceptibility variations in Alaskan loess during the Quaternary. Geology 18, 40-43.

Bergametti, G., Gomes, L., Coude-Gaussen, G., Rognon, P., Le Coutumer, M.-N., 1989. African dust observed over Canary Islands: source-regions identification and transport pattern for some summer situations. Journal of Geophysical Research $94,14855-14864$

Berger, A., Loutre, M.F., 1991. Insolation values for the climate of the last 10 million years. Quaternary Science Reviews 10, 297-317.

Berryman, K.R., 1993. Distribution, age, and deformation of late Pleistocene marine terraces at Mahia Peninsula, Hikurangi subduction margin, New Zealand. Tectonics 12, 1365-1379.

Bettis III, E.A., Muhs, D.R., Roberts, H.M., Wintle, A.G., 2003. Last glacial loess in the conterminous USA. Quaternary Science Reviews 22, 1907-1946.

Betzer, P.R., Carder, K.L., Duce, R.A., Merrill, J.T., Tindale, N.W., Uematsu, M., Costello, D.K., Young, R.W., Feely, R.A., Breland, J.A., Bernstein, R.E., Greco, A.M., 1988. Long-range transport of giant mineral aerosol particles. Nature 336, 568-571.

Birkeland, P.W., 1999. Soils and Geomorphology. Oxford University Press, London, $430 \mathrm{pp}$.

Biscaye, P.E., Grousset, F.E., Revel, M., VanderGaast, S., Zielinski, G.A., Vaars, A. Kukla, G., 1997. Asian provenance of glacial dust (stage 2) in the Greenland Ice Sheet Project 2 Ice Core, Summit, Greenland. Journal of Geophysical Research 102 (C12), 26765-26781.

Blatt, H., 1987. Oxygen isotopes and the origin of quartz. Journal of Sedimentary Petrology 57, 373-377.

Bowler, J.M., 1976. Aridity in Australia: age, origins and expression in aeolian landforms and sediments. Earth-Science Reviews 12, 279-310.

Bowler, J.M., Wyrwoll, K.-H., Lu, Y., 2001. Variations of the northwest Australian summer monsoon over the last 300,000 years: the paleohydrological record of the Gregory (Mulan) Lakes system. Quaternary International 83-85, 63-80.

Bridges, N.T., Muhs, D.R., 2012. Duststones on Mars: source, transport, deposition, and erosion. In: Grotzinger, J., Milliken, R. (Eds.), Sedimentary Geology of Mars, vol. 102. SEPM Special Publication 5 pp.169-182.

Bridges, N.T., Banks, M.E., Beyer, R.A., Chuang, F.C., Noe Dobrea, E.Z., Herkenhoff, K.E., Keszthelyi, L.P., Fishbaugh, K.E., McEwen, A.S., Michaels, T.I., Thomson, B.J., Wray, J.J., 2010. Eolian bedforms, yardangs, and indurated surfaces in the Tharsis Montes as seen by the HiRISE camera: evidence for dust aggregates. Icarus 205, 165-182.

Bristow, C.S., Drake, N., Armitage, S., 2009. Deflation in the dustiest place on Earth: the Bodélé Depression, Chad. Geomorphology 105, 50-58.

Busacca, A.J., Begét, J.E., Markewich, H.W., Muhs, D.R., Lancaster, N., Sweeney, M.R., 2004. Eolian sediments. In: Gillespie, A.R., Porter, S.C., Atwater, B.F. (Eds.), The Quaternary Period in the United States. Elsevier, Amsterdam, pp. 275-309.

Butler, B.E., 1956. Parna - an aeolian clay. Australian Journal of Science 18, 145-151.

Butler, B.E., 1974. A contribution towards the better specification of parna and some other aeolian clays in Australia. Zeitschrift für Geomorphologie 20 (Suppl.), 106-116.

Caquineau, S., Gaudichet, A., Gomes, L., Legrand, M., 2002. Mineralogy of Saharan dust transported over northwestern tropical Atlantic Ocean in relation to source regions. Journal of Geophysical Research 107 (D15), 4251. http://dx.doi.org/ 10.1029/2000JD247

Carey, S.N., Sigurdsson, H., 1980. The Roseau ash: deep-sea tephra deposits from a major eruption on Dominica, Lesser Antilles arc. Journal of Volcanology and Geothermal Research 7, 67-86.

Carlson, T.N., Prospero, J.M., 1972. The large-scale movement of Saharan air outbreaks over the Northern Equatorial Atlantic. Journal of Applied Meteorology 11, 283-297.

Cattle, S.R., Greene, R.S.B., McPherson, A.A., 2009. The role of climate and local regolith-landscape processes in determining the pedological characteristics of aeolian dust deposits across south-eastern Australia. Quaternary International 209, 95-106.

Chiapello, I., Bergametti, G., Chatenet, B., Bousquet, P., Dulac, F., Santos Soares, E.S., 1997. Origins of African dust transported over the northeastern tropical Atlantic. Journal of Geophysical Research 102, 13701-13709.

Chuey, J.M., Rea, D.K., Pisias, N.G., 1987. Late Pleistocene paleoclimatology of the central equatorial Pacific: a quantitative record of eolian and carbonate deposition. Quaternary Research 28, 323-339.

COHMAP Members, 1988. Climatic changes of the last 18,000 years: observations and model simulations. Science 241, 1043-1052.

Coudé-Gaussen, G., Rognon, P., Bergametti, G., Gomes, L., Strauss, B., Gros, J.M., Le Coustumer, M.N., 1987. Saharan dust on Fuerteventura Island (Canaries): chemical and mineralogical characteristics, air mass trajectories, and probable sources. Journal of Geophysical Research 92, 9753-9771.

Crouvi, O., Amit, R., Enzel, Y., Porat, N., Sandler, A., 2008. Sand dunes as a major proximal dust source for late Pleistocene loess in the Negev Desert, Israel. Quaternary Research 70, 275-282.

Crouvi, O., Amit, R., Enzel, Y., Gillespie, A.R., 2010. Active sand seas and the formation of desert loess. Quaternary Science Reviews 29, 2087-2098.
Crusius, J., Schroth, A.W., Gassó, S., Moy, C.M., Levy, R.C., Gatica, M., 2011. Glacial flour dust storms into the Gulf of Alaska: hydrologic and meteorological controls and their importance as a source of bioavailable iron. Geophysical Research Letters 38. http://dx.doi.org/10.1029/2010GL046573.

Dan, J., Yaalon, D.H., 1971. On the origin and nature of the paleopedological formations in the coastal desert fringe areas of Israel. In: Yaalon, D.H. (Ed.), Paleopedology: Origin, Nature and Dating of Paleosols. Israel Universities Press, Jerusalem, pp. 245-260.

Dansgaard, W., Clausen, H.B., Gundestrup, N., Hammer, C.U., Johnsen, S.F. Kristinsdottir, P.M., Reeh, N., 1982. A new Greenland deep ice core. Science 218, 1273-1277.

Darwin, C., 1846. An account of the fine dust which falls upon vessels in the Atlantic Ocean. Quarterly Journal of the Geological Society of London 2, 26-30.

DeDeckker, P., Norman, M., Goodwin, I.D., Wain, A., Gingele, F.X., 2010. Lead isotopic evidence for an Australian source of aeolian dust to Antarctica at times over the last 170,000 years. Palaeogeography, Palaeoclimatology, Palaeoecology 285, 205-223.

Delmonte, B., Basile-Doelsch, I., Petit, J.-R., Maggi, V., Revel-Rolland, M., Michard, A., Jagoutz, E., Grousset, F., 2004. Comparing the Epica and Vostok dust records during the last 220,000 years: stratigraphical correlation and provenance in glacial periods. Earth-Science Reviews 66, 63-87.

Delmonte, B., Andersson, P.S., Hansson, M., Schoberg, H., Petit, J.R., Basile- Doelsch, I., Maggi, V., 2008. Aeolian dust in East Antarctica (EPICA-Dome C and Vostok): provenance during glacial ages over the last $800 \mathrm{ka}$. Geophysical Research Letters 35, L07703.

Delmonte, B., Andersson, P.S., Schöberg, H., Hansson, M., Petit, J.R., Delmas, R. Gaiero, D.M., Maggi, V., Frezzotti, M., 2010. Geographic provenance of aeolian dust in East Antarctica during Pleistocene glaciations: preliminary results from Talos Dome and comparison with East Antarctic and new Andean ice core data. Quaternary Science Reviews 29, 256-264.

DeMenocal, P.B., Ruddiman, W.F., Pokras, E.M., 1993. Influences of high- and lowlatitude processes on African terrestrial climate: Pleistocene eolian records from equatorial Atlantic Ocean Drilling Program site 663. Paleoceanography 8, 209-242.

DeMenocal, P., Ortiz, J., Guilderson, T., Adkins, J., Sarnthein, M., Baker, L., Yarusinsky, M., 2000. Abrupt onset and termination of the African Humid Period: rapid climate responses to gradual insolation forcing. Quaternary Science Reviews 19 347-361.

Dietrich, S., Seelos, K., 2010. The reconstruction of easterly wind directions for the Eifel region (Central Europe) during the period 40.3-12.9 ka BP. Climate of the Past 6, 145-154.

Ding, Z., Yu, Z., Rutter, N.W., Liu, T., 1994. Towards an orbital time scale for Chinese loess deposits. Quaternary Science Reviews 13, 39-70.

Ding, Z.L., Sun, J.M., Liu, T.S., Zhu, R.X., Yang, S.L., Guo, B., 1998. Wind-blown origin of the Pliocene red clay formation in the central Loess Plateau, China. Earth and Planetary Science Letters 161, 135-143.

Ding, Z.L., Derbyshire, E., Yang, S.L., Sun, J.M., Liu, T.S., 2005. Stepwise expansion of desert environment across northern China in the past 3.5 Ma and implications for monsoon evolution. Earth and Planetary Science Letters 237, 45-55.

Dodonov, A.E., 2007. Central Asia. In: Elias, S. (Ed.), The Encyclopedia of Quaternary Sciences. Elsevier, Amsterdam, pp. 1418-1429.

Dubief, J., 1979. Review of the north African climate with particular emphasis on the production of eolian dust in the Sahel zone and in the Sahara. In: Morales, C. (Ed.), Saharan Dust: Mobilization, Transport, Deposition. John Wiley \& Sons, Chichester, pp. 27-48.

Dyke, A.S., Andrews, J.T., Clark, P.U., England, J.H., Miller, G.H., Shaw, J., Veillette, J.J., 2002. The Laurentide and Innuitian ice sheets during the Last Glacial Maximum. Quaternary Science Reviews 21, 9-31.

Eden, D.N., Hammond, A.P., 2003. Dust accumulation in the New Zealand region since the last glacial maximum. Quaternary Science Reviews 22, 2037-2052.

EPICA Community Members, 2004. Eight glacial cycles from an Antarctic ice core. Nature 429, 623-628

EPICA Community Members, 2006. One-to-one coupling of glacial climate variability in Greenland and Antarctica. Nature 444, 195-198.

Falkowski, P.G., Barber, R.T., Smetacek, V., 1998. Biogeochemical controls and feedbacks on ocean primary production. Science 281, 200-206.

Filipsson, H.L., Romero, O.E., Stuut, J.-B.W., Donner, B., 2011. Relationships between primary productivity and bottom-water oxygenation off northwest Africa during the last deglaciation. Journal of Quaternary Science 26, 448-456.

Flint, R.F., 1971. Glacial and Quaternary Geology. John Wiley \& Sons, Inc., New York, $906 \mathrm{pp}$.

Forster, P., Ramaswamy, V., Artaxo, P., Berntsen, T., Betts, R., Fahey, D.W., Haywood, J., Lean, J., Lowe, D.C., Myhre, G., Nganga, J., Prinn, R., Raga, G., Schulz, M., Van Dorland, R., 2007. Changes in atmospheric constituents and in radiative forcing. In: Solomon, S., Qin, D., Manning, M., Chen, Z, Marquis, M., Averyt, K.B., Tignor, M., Miller, H.L. (Eds.), Climate Change 2007: The Physical Science Basis. Contribution of Working Group I to the Fourth Assessment Report of the Intergovernmental Panel on Climate Change. Cambridge University Press, Cambridge, United Kingdom and New York, NY, USA, pp. 129-234.

Frechen, M., Oches, E.A., Kohfeld, K.E., 2003. Loess in Europe - mass accumulation rates during the Last Glacial Period. Quaternary Science Reviews 22, 18351857

Frechen, M., Kehl, M., Rolf, C., Sarvati, R., Skowronek, A., 2009. Loess chronology of the Caspian Lowland in northern Iran. Quaternary International 198, 220-233.

Frye, J.C., Glass, H.D., Willman, H.B., 1968. Mineral zonation of Woodfordian loesses of Illinois. Illinois State Geological Survey Circular 427, 1-44. 
Fullerton, D.S., Bush, C.A., Pennell, J.N., 2003. Map of surficial deposits and materials in the eastern and central United States (east of 102 degrees West longitude). US Geological Survey Miscellaneous Investigations Series Map I-2789, scale 1: $2,500,000$.

Fullerton, D.S., Colton, R.B., Bush, C.A., Straub, A.W., 2004. Map showing spatial and temporal relations of mountain and continental glaciations on the Northern Plains, primarily in northern Montana and northwestern North Dakota. US Geological Survey Scientific Investigations Map 2843, scale 1: 1,000,000.

Gaiero, D.M., 2007. Dust provenance in Antarctic ice during glacial periods: from where in southern South America? Geophysical Research Letters 34, L17707.

Gaiero, D.M., Probst, J.-L., Depetris, P.J., Bidart, S.M., Leleyter, L., 2003. Iron and other transition metals in Patagonian riverborne and windborne materials: geochemical control and transport to the southern South Atlantic Ocean Geochimica et Cosmochimica Acta 67, 3603-3623.

Genthon, C., 1992. Simulations of desert dust and sea-salt aerosols in Antarctica with a general circulation model of the atmosphere. Tellus B 44, 371.

Gile, L.H., Grossman, R.B., 1979. The Desert Project Soil Monograph: Soils and Landscapes of a Desert Region Astride the Rio Grande Valley near Las Cruces, New Mexico. US Department of Agriculture, Soil Conservation Service, Lincoln, NE.

Gile, L.H., Peterson, F.F., Grossman, R.B., 1966. Morphological and genetic sequences of carbonate accumulation in desert soils. Soil Science 101, 347-360.

Gile, L.H., Hawley, J.W., Grossman, R.B., 1981. Soils and geomorphology in the Basin and Range area of Southern New Mexico: Guidebook to the Desert Project. Socorro, NM: New Mexico Bureau of Mines and Mineral Resources, Memoir 39.

Gillette, D.A., Hanson, K.J., 1989. Spatial and temporal variability of dust production caused by wind erosion in the United States. Journal of Geophysical Research 94, 2197-2206.

Glaccum, R.A., Prospero, J.M., 1980. Saharan aerosols over the tropical north Atlantic - mineralogy. Marine Geology 37, 295-321.

Goudie, A.S., Middleton, N.J., 2001. Saharan dust storms: nature and consequences. Earth-Science Reviews 56, 179-204.

Goudie, A.S., Middleton, N.J., 2006. Desert Dust in the Global System. Springer, Heidelberg, $287 \mathrm{pp}$.

Graham, I.J., Ditchburn, R.G., Whitehead, N.E., 2001. Be isotope analysis of a 0 500 ka loess-paleosol sequence from Rangitatau East. New Zealand. Quaternary International 76/77, 29-42.

Grainger, R.G., Highwood, E.J., 2003. Changes in stratospheric composition, chemistry, radiation and climate caused by volcanic eruptions. Geological Society of London Special Publications 213, 329-347.

Greene, R.S.B., Cattle, S.R., McPherson, A.A., 2009. Role of eolian dust deposits in landscape development and soil degradation in southeastern Australia. Australian Journal of Earth Sciences 56, S55-S65.

Grimley, D.A., 2000. Glacial and nonglacial sediment contributions to Wisconsin episode loess in the central United States. Geological Society of America Bulletin 112, 1475-1495.

Grimley, D.A., Follmer, L.R., McKay, E.D., 1998. Magnetic susceptibility and minera zonations controlled by provenance in loess along the Illinois and centra Mississippi River valleys. Quaternary Research 49, 24-36.

Grimley, D.A., Follmer, L.R., Hughes, R.E., Solheid, P.A., 2003. Modern, Sangamon and Yarmouth soil development in loess of unglaciated southwestern Illinois. Quaternary Science Reviews 22, 225-244.

Grootes, P.M., Stuiver, M., White, J.W.C., Johnsen, S.J., Jouzel, J., 1993. Comparison of oxygen isotope records from the GISP2 and GRIP Greenland ice cores. Nature 366, 552-554.

Grousset, F.E., Rognon, P., Coudé-Gaussen, G., Pédemay, P., 1992. Origins of periSaharan dust deposits traced by their $\mathrm{Nd}$ and $\mathrm{Sr}$ isotopic composition. Palaeogeography, Palaeoclimatology, Palaeoecology 93, 203-212.

Haase, D., Fink, J., Haase, G., Ruske, R., Pésci, M., Richter, H., Altermann, M., Jäger, K.D. 2007. Loess in Europe - its spatial distribution based on a European Loess Map, scale 1:2,500,000. Quaternary Science Reviews 26, 1301-1312.

Hallet, B., Hunter, L., Bogen, J., 1996. Rates of erosion and sediment evacuation by glaciers: a review of field data and their implications. Global and Planetary Change 12, 213-235.

Hamann, Y., Ehrmann, W., Schmiedl, G., Kuhnt, T., 2009. Modern and late Quaternary clay mineral distribution in the area of the SE Mediterranean Sea Quaternary Research 71, 453-464.

Hamann, Y., Ehrmann, W., Schmiedl, G., Krüger, S., Stuut, J.-B., Kuhnt, T., 2008 Sedimentation processes in the Eastern Mediterranean Sea during the Late Glacial and Holocene revealed by end-member modelling of the terrigenous fraction in marine sediments. Marine Geology 248, 97-114.

Harrison, S.P., Kohfeld, K.E., Roelandt, C., Claquin, T., 2001. The role of dust in climate changes today, at the last glacial maximum and in the future. EarthScience Reviews 54, 43-80.

Herrmann, L., Stahr, K., Jahn, R., 1999. The importance of source region identification and their properties for soil-derived dust: the case of Harmattan dust sources for eastern West Africa. Contributions to Atmospheric Physics 72, 141-150.

Hesse, P.P., 1994. The record of continental dust from Australia in Tasman Sea Sediments. Quaternary Science Reviews 13, 257-272.

Hesse, P.P., McTainsh, G.H., 1999. Last glacial maximum to early Holocene wind strength in the mid-latitudes of the Southern Hemisphere from aeolian dust in the Tasman Sea. Quaternary Research 52, 343-349.

Hesse, P.P., McTainsh, G.H., 2003. Australian dust deposits: modern processes and the Quaternary record. Quaternary Science Reviews 22, 2007-2035.
Holz, C., Stuut, J.-B.W., Henrich, R., 2004. Terrigenous sedimentation processes along the continental margin off NW Africa: implications from grain-size analysis of seabed sediments. Sedimentology 51, 1145-1154.

Holz, C., Stuut, J.-B.W., Henrich, R., Meggers, H., 2007. Variability in terrigenous sedimentation processes off northwest Africa and its relation to climate changes: Inferences from grain-size distributions of a Holocene marine sediment record. Sedimentary Geology 202, 499-508.

Hovan, S.A., Rea, D.K., Pisias, N.G., 1991. Late Pleistocene climate and oceanic variability recorded in northwest Pacific sediments. Paleoceanography 6, 349370.

Imbrie, J., Hays, J.D., Martinson, D.G., McIntyre, A., Mix, A.C., Morley, J.J., Pisias, N.G., Prell, W.L., Shackleton, N.J., 1984. The orbital theory of Pleistocene climate: support from a revised chronology of the marine $\delta^{18} \mathrm{O}$ record. In: Berger, A., Imbrie, J., Hays, H., Kukla, G., Saltzman, B. (Eds.), Milankovitch and Climate: Understanding the Response to Astronomical Forcing. D. Reidel Publishing, Dordrecht, p. 269

Jackson, M.G., Oskarsson, N., Trønnes, R.G., McManus, J.F., Oppo, D.W., Grönvold, K., Hart, S.R., Sachs, J.P., 2005. Holocene loess deposition in Iceland: evidence for millennial-scale atmosphere-ocean coupling in the North Atlantic. Geology 33, 509-512.

Jackson, M.L., Levelt, T.W.M., Syers, J.K., Rex, R.W., Clayton, R.N., Sherman, G.D., Uehara, G., 1971. Geomorphological relationships of tropospherically derived quartz in the soils of the Hawaiian islands. Soil Science Society of America Proceedings 35, 515-525.

Jickells, T.D., An, Z.S., Andersen, K.K., Baker, A.R., Bergametti, G., Brooks, N., Cao, J.J., Boyd, P.W., Duce, R.A., Hunter, K.A., Kawahata, H., Kubilay, N., LaRoche, J., Liss, P.S., Mahowald, N., Prospero, J.M., Ridgwell, A.J., Tegen, I., Torres, R., 2005. Global iron connections between desert dust, ocean biogeochemistry, and climate. Science 308, 67-71.

Joussaume, S., 1990. Three-dimensional simulations of the atmospheric cycle of desert dust particles using a general circulation model. Journal of Geophysical Research 95, 1909-1941.

Joussaume, S., 1993. Paleoclimatic tracers: an investigation using an atmospheric general circulation model under Ice Age conditions: 1. Desert dust. Journal of Geophyscial Research 98, 2767-2805.

Kahn, R.A., Martin, T.Z., Zurek, R.W., Lee, S.W., 1992. The Martian dust cycle. In: Kieffer, H.H., Jakosky, B.M., Snyder, C.W., Matthews, M.S. (Eds.), Mars. University of Arizona Press, Tucson, Arizona, pp. 1017-1053.

Kallos, G., Papadopoulos, A., Katsafados, P., Nickovic, S., 2006. Transatlantic Saharan dust transport: model simulation and results. Journal of Geophysical Research 111. http://dx.doi.org/10.1029/2005JD006207.

Kalu, A.E., 1979. The African dust plume: its characteristics and propagation across west Africa in winter. In: Morales, C. (Ed.), Saharan Dust: Mobilization, Transport, Deposition. John Wiley \& Sons, Chichester, pp. 95-118.

Kohfeld, K.E., Harrison, S.P., 2000. How well can we simulate past climates? Evaluating the models using global palaeoenvironmental datasets. Quaternary Science Reviews 19, 321-347.

Kohfeld, K.E., Harrison, S.P., 2001. DIRTMAP: the geological record of dust. EarthScience Reviews 54, 81-114.

Kohfeld, K.E., Tegen, I., 2007. Record of mineral aerosols and their role in the Earth system. In: Holland, H.D., Turekian, K.K. (Eds.), Treatise on Geochemistry. Elsevier, 26 p. <http://www.sciencedirect.com/science/referenceworks/ 9780080437514>

Kolla, V., Biscaye, P.E., Hanley, A.F., 1979. Distribution of quartz in late Quaternary Atlantic sediments in relation to climate. Quaternary Research 11, 261-277.

Koren, I., Kaufman, Y.J., Washington, R., Todd, M.C., Rudich, Y., Martins, J.V., Rosenfeld, D., 2006. The Bodélé depression: a single spot in the Sahara that provides most of the mineral dust to the Amazon forest. Environmental Research Letters 1. http://dx.doi.org/10.1088/1748-9326/1/1/014005.

Kukla, G., An, Z., 1989. Loess stratigraphy in central China. Palaeogeography, Palaeoclimatology, Palaeoecology 72, 203-225.

Kurtz, A.C., Derry, L.A., Chadwick, O.A., 2001. Accretion of Asian dust to Hawaiian soils: isotopic, elemental, and mineral mass balances. Geochimica et Cosmochemica Acta 65, 1971-1983.

Lemmon, M.T., Wolff, M.J., Smith, M.D., Clancy, R.T., Banfield, D., Landis, G.A., Ghosh, A., Smith, P.H., Spanovich, N., Whitney, B., Whelley, P., Greeley, R., Thompson, S., Bell III, J.F., Squyres, S.W., 2004. Atmospheric imaging results from the Mars Exploration Rovers: spirit and opportunity. Science 204, 1753-1756.

Leonard, A.B., 1952. Illinoian and Wisconsinan molluscan faunas in Kansas. University of Kansas Paleontological Contributions 4, 1-38.

Leonard, A.B., Frye, J.C., 1954. Ecological conditions accompanying loess deposition in the Great Plains region of the United States. Journal of Geology 62, 399-404.

Leonard, A.B., Frye, J.C., 1960. Wisconsinan molluscan faunas of the Illinois Valley region. Illinois State Geological Survey Circular 304, 1-32.

Liu, T., 1985. Loess in China, 2nd ed. China Ocean Press/Springer-Verlag, Beijing/ Berlin, $224 \mathrm{pp}$.

Lu, H., Vandenberghe, J., An, Z., 2001. Aeolian origin and palaeoclimatic implications of the 'Red Clay' (north China) as evidenced by grain-size distribution. Journal of Quaternary Science 16, 89-97.

Lu, Y.C., Wang, X.L., Wintle, A.G., 2007. A new OSL chronology for dust accumulation in the last $130,000 \mathrm{yr}$ for the Chinese Loess Plateau. Quaternary Research 67, $152-160$.

Maher, B.A., Thompson, R., Zhou, L.P., 1994. Spatial and temporal reconstructions of changes in the Asian palaeomonsoon: a new mineral magnetic approach. Earth and Planetary Science Letters 125, 461-471. 
Maher, B.A., Prospero, J.M., Mackie, D., Gaiero, D., Hesse, P., Balkanski, Y., 2010. Global connections between aeolian dust, climate and ocean biogeochemistry at the present day and at the last glacial maximum. Earth Science Reviews 99, 61-97.

Mahowald, N., Kohfeld, K., Hansson, M., Balkanski, Y., Harrison, S.P., Prentice, I.C., Schulz, M., Rodhe, H., 1999. Dust sources and deposition during the last glacial maximum and current climate: a comparison of model results with paleodata from ice cores and marine sediments. Journal of Geophysical Research 104, 15895-15916.

Mahowald, N.M., Muhs, D.R., Levis, S., Rasch, P.J., Yoshioka, M., Zender, C.S., Luo, C., 2006. Change in atmospheric mineral aerosols in response to climate: last glacial period, preindustrial, modern, and doubled carbon dioxide climates. Journal of Geophysical Research 111. http://dx.doi.org/10.1029/2005JD006653.

Mahowald, N.M., Engelstaedter, S., Luo, C., Sealy, A., Artaxo, P., Benitez-Nelson, C., Bonnet, S., Chen, Y., Chuang, P.Y., Cohen, D.D., Dulac, F., Herut, B., Johansen, A.M., Kubilay, N., Losno, R., Maenhaut, W., Paytan, A., Prospero, J.M., Shank, L.M., Siefert, R.L., 2009. Atmospheric iron deposition: global distribution, variability, and human perturbations. Annual Review of Marine Science 1, 245-278.

Martin, J.H., 1990. Glacial-interglacial $\mathrm{CO}_{2}$ change: the iron hypothesis. Paleoceanography 5, 1-13.

Martinson, D.G., Pisias, N.G., Hays, J.D., Imbrie, J., Moore Jr., T.C., Shackleton, N.J., 1987. Age dating and the orbital theory of the ice ages: development of a high-resolution 0 to 300,000-year chronostratigraphy. Quaternary Research 27, $1-29$.

Mason, J.A., 2001. Transport direction of Peoria Loess in Nebraska and implications for loess sources on the central Great Plains. Quaternary Research 56, 79-86.

Mason, J.A., Jacobs, P.M., Hanson, P.R., Miao, X., Goble, R.J., 2003. Sources and paleoclimatic significance of Holocene Bignell Loess, central Great Plains, USA. Quaternary Research 60, 330-339.

Mason, J.A., Swinehart, J.B., Hanson, P.R., Loope, D.B., Goble, R.J., Miao, X., Schmeisser, R.L., 2011. Late Pleistocene dune activity in the central Great Plains, USA. Quaternary Science Reviews 30, 3858-3870.

Matsu'ura, T., Miyagi, I., Furusawa, A., 2011. Late Quaternary cryptotephra detection and correlation in loess in northeastern Japan using cummingtonite geochemistry. Quaternary Research 75, 624-635.

Mayewski, P.A., Meeker, L.D., Twickler, M.S., Whitlow, S., Yang, Q.Z., Lyons, W.B., Prentice, M., 1997. Major features and forcing of high-latitude northern hemisphere atmospheric circulation using a 110,000-year-long glaciochemical series. Journal of Geophysical Research 102 (C12), 26345-26366.

Mayewski, P.A., Meeker, L.D., Whitlow, S., Twickler, M.S., Morrison, M.C., Alley, R.B., Bloomfield, P., Taylor, K.C., 1993. The atmosphere in the Younger Dryas. Science 261, 195-197.

Mayewski, P.A., Meeker, L.D., Whitlow, S., Twickler, M.S., Morrison, M.C., Bloomfield, P., Bond, G.C., Alley, R.B., Gow, A.J., Grootes, P.M., Meese, D.A., Ram, M., Taylor, K.C., Wumkes, W., 1994. Changes in atmospheric circulation and ocean ice cover over the North Atlantic during the last 41,000 years. Science 263, 1747-1751.

McKay, E.D., 1979. Wisconsinan loess stratigraphy of Illinois. In: Follmer, L.R., McKay, E.D., Lineback, J.A., Gross, D.L. (Eds.), Wisconsinan, Sangamonian, and Illinoian Stratigraphy in Central Illinois, Illinois State Geological Survey Guidebook, vol. 13. pp. 95-108.

McTainsh, G., 1984. The nature and origin of the aeolian mantles of central northern Nigeria. Geoderma 33, 13-37.

McTainsh, G., 1985. Dust processes in Australia and West Africa: a comparison. Search 16, 104-106.

McTainsh, G.H., 1989. Quaternary aeolian dust processes and sediments in the Australian region. Quaternary Science Reviews 8, 235-253.

McTainsh, G., Walker, P.H., 1982. Nature and distribution of Harmattan dust. Zeitschrift für Geomorphologie 26, 417-435.

Meco, J., Muhs, D.R., Fontugne, M., Ramos, A.J.G., Lomoschitz, A., Patterson, D., 2011. Late Pliocene and Quaternary Eurasian locust infestations in the Canary Archipelago. Lethaia 44, 440-454.

Meyer, I., Davies, G.R., Stuut, J.-B.W., 2011. Grain size control on Sr-Nd isotope provenance studies and impact on paleoclimate reconstructions: an example from deep-sea sediments offshore NW Africa. Geochemistry, Geophysics, Geosystems 12, Q03005. http://dx.doi.org/10.1029/2010GC003355.

Miao, X., Mason, J.A., Goble, R.J., Hanson, P.R., 2005. Loess record of dry climate and aeolian activity in the early- to mid-Holocene, central Great Plains, North America. The Holocene 15, 339-346.

Miao, X., Mason, J.A., Swinehart, J.B., Loope, D.B., Hanson, P.R., Goble, R.J., Liu, X., 2007. A 10,000 year record of dune activity, dust storms, and severe drought in the central Great Plains. Geology 35, 119-122.

Middleton, N.J., Goudie, A.S., 2001. Saharan dust: sources and trajectories. Transactions of the Institute of British Geographers NS 26, 165-181.

Minnis, P., Harrison, E.F., Stowe, L.L., Gibson, G.G., Denn, F.M., Doelling, D.R., Smith Jr., W.L., 1993. Radiative climate forcing by the Mount Pinatubo eruption. Science 259, 1411-1415.

Moreno, A., Targarona, J., Henderiks, J., Canals, M., Freudenthal, T., Meggers, H. 2001. Orbital forcing of dust supply to the North Canary Basin over the last 250 kyr. Quaternary Science Reviews 20, 1327-1339.

Moreno, A., Nave, S., Kuhlmann, H., Canals, M., Targarona, J., Freudenthal, T. Abrantes, F., 2002. Productivity response in the North Canary Basin to climate changes during the last $250000 \mathrm{yr}$ : a multi-proxy approach. Earth and Planetary Science Letters 196, 147-159.

Muhs, D.R., 2007. Loess deposits, origins, and properties. In: Elias, S. (Ed.), The Encyclopedia of Quaternary Sciences. Elsevier, Amsterdam, pp. 1405-1418.
Muhs, D.R., in press. Loess and its geomorphic, stratigraphic and paleoclimatic significance in the Quaternary. In: Sherman, D., Baas, A., Lancaster, N. (Eds.), Treatise on Geomorphology. Elsevier.

Muhs, D.R., Bettis III, E.A., 2000. Geochemical variations in Peoria Loess of western Iowa indicate paleowinds of midcontinental North America during last glaciation. Quaternary Research 53, 49-61.

Muhs, D.R., Bettis III, E.A., 2003. Quaternary loess-paleosol sequences as examples of climate-driven sedimentary extremes. Geological Society of America Special Paper 370, 53-74.

Muhs, D.R., Bettis III, E.A., Been, J., McGeehin, J., 2001. Impact of climate and parent material on chemical weathering in loess-derived soils of the Mississippi River Valley. Soil Science Society of America Journal 65, 1761-1777.

Muhs, D.R., Ager, T.A., Bettis III, E.A., McGeehin, J., Been, J.M., Begét, J.E., Pavich, M.J. Stafford Jr., T.W., Pinney, D., 2003a. Stratigraphy and paleoclimatic significance of late Quaternary loess-paleosol sequences of the last interglacial-glacial cycle in central Alaska. Quaternary Science Reviews 22, 1947-1986.

Muhs, D.R., Ager, T.A., Been, J., Bradbury, J.P., Dean, W.E., 2003b. A late Quaternary record of eolian silt deposition in a maar lake, St. Michael Island, western Alaska. Quaternary Research 60, 110-122.

Muhs, D.R., McGeehin, J.P., Beann, J., Fisher, E., 2004. Holocene loess deposition and soil formation as competing processes, Matanuska Valley, southern Alaska. Quaternary Research 61, 265-276.

Muhs, D.R., Budahn, J., Prospero, J.M., Carey, S.N., 2007a. Geochemical evidence for African dust inputs to soils of western Atlantic islands: Barbados, the Bahamas and Florida. Journal of Geophysical Research 112, F02009. http://dx.doi.org/ 10.1029/2005JF000445

Muhs, D.R., Budahn, J., Reheis, M., Beann, J., Skipp, G., Fisher, E., 2007b. Airborne dust transport to the eastern Pacific Ocean off southern California: evidence from San Clemente Island. Journal of Geophysical Research 112, D13203. http:// dx.doi.org/10.1029/2006JD007577.

Muhs, D.R, Bettis III, E.A. Aleinikoff, J., McGeehin, J.P., Beann, J. Skipp, G, Marshall, B.D., Roberts, H.M., Johnson, W.C., Benton, R., 2008a. Origin and paleoclimatic significance of late Quaternary loess in Nebraska: evidence from stratigraphy, chronology, sedimentology, and geochemistry. Geological Society of America Bulletin 120, 1378-1407.

Muhs, D.R., Ager, T.A., Skipp, G., Beann, J., Budahn, J.R., McGeehin, J.P., 2008b. Paleoclimatic significance of chemical weathering in loess-derived paleosols of subarctic central Alaska. Arctic, Antarctic, and Alpine Research 40, 396-411.

Muhs, D.R., Budahn, J., Johnson, D.L., Reheis, M., Beann, J., Skipp, G., Fisher, E., Jones, J.A., 2008c. Geochemical evidence for airborne dust additions to soils in Channel Islands National Park, California. Geological Society of America Bulletin 120, 106-126.

Muhs, D.R., Budahn, J., Skipp, G., Prospero, J.M., Patterson, D., Bettis III, E.A., 2010 Mineralogical and geochemical evidence for Sahara and Sahel dust additions to Quaternary soils on Lanzarote, eastern Canary Islands, Spain. Terra Nova 22, 399-410.

Mulitza, S., Prange, M., Stuut, J.-B., Zabel, M., von Dobeneck, T., Itambi, A.C., Nizou, J., Schulz, M., Wefer, G., 2008. Sahel megadroughts triggered by glacial slowdowns of Atlantic meridional overturning. Paleoceanography 23, PA4206. http:// dx.doi.org/10.1029/2008PA001637.

Murray, R.W., Knowlton, C., Leinen, M., Mix, A.C., Polsky, C.H., 2000. Export production and carbonate dissolution in the central equatorial Pacific Ocean over the past 1 Myr. Paleoceanography 15, 570-592.

Neff, J.C., Ballantyne, A.P., Farmer, G.L., Mahowald, N.M., Conroy, J.L., Landry, C.C., Overpeck, J.T., Painter, T.H., Lawrence, C.R., Reynolds, R.L., 2008. Increasing eolian dust deposition in the western United States linked to human activity. Nature Geoscience 1, 189-195.

NGRIP Members, 2004. High-resolution record of Northern Hemisphere climate extending into the last interglacial period. Nature 431, 147-151.

Olivarez, A.M., Owen, R.M., Rea, D.K., 1991. Geochemistry of eolian dust in Pacific pelagic sediments: implications for paleoclimatic interpretations. Geochimica et Cosmochimica Acta 55, 2147-2158.

Overpeck, J., Rind, D., Lacis, A., Healy, R., 1996. Possible role of dust-induced regional warming in abrupt climate change during the last glacial period. Nature 384 447-449.

Perry, K.D., Cahill, T.A., Eldred, R.A., Dutcher, D.D., Gill, T.E., 1997. Long-range transport of North African dust to the eastern United States. Journal of Geophysical Research 102, 11225-11238.

Petit, J.-R., Briat, M., Royer, A., 1981. Ice age aerosol content from East Antarctic ice core samples and past wind strength. Nature 293, 391-394.

Petit, J.-R., Jouzel, J., Raynaud, D., Barkov, N.I., Barnola, J.M., Basile, I., Bender, M. Chappellaz, J., Davis, J., Delaygue, G., Delmotte, M., Kotlyakov, V.M., Legrand, M., Lipenkov, V., Lorius, C., Pépin, L., Ritz, C., Saltzman, E., Stievenard, M., 1999. Climate and atmospheric history of the past 420,000 years from the Vostok Ice Core, Antarctica. Nature 399, 429-436.

Péwé, T.L., 1975. Quaternary geology of Alaska. US Geological Survey Professional Paper 835, 1-145.

Péwé, T.L., Journaux, A., 1983. Origin and character of loesslike silt in unglaciated south-central Yakutia, Siberia, USSR. US Geological Survey Professional Paper 1262, $46 \mathrm{pp}$.

Pigati, J.S., Rech, J.A., Nekola, J.C., 2010. Radiocarbon dating of small terrestrial gastropod shells in North America. Quaternary Geochronology 5, 519-532.

Porter, S.C., 2001. Chinese loess record of monsoon climate during the last glacialinterglacial cycle. Earth-Science Reviews 54, 115-128.

Porter, S.C., An, Z., 1995. Correlation between climate events in the North Atlantic and China during the last glaciation. Nature 375, 305-308. 
Porter, S.C., Hallet, B., Wu, X., An, Z., 2001. Dependence of near-surface magnetic susceptibility on dust accumulation rate and precipitation on the Chinese Loess Plateau. Quaternary Research 55, 271-283.

Prins, M.A., Weltje, G.J., 1999. End-member modeling of siliciclastic grain-size distributions: the late Quaternary record of eolian and fluvial sediment supply to the Arabian Sea and its paleoclimatic significance. SEPM Special Publications 63, 91-111.

Prospero, J.M., 1999. Long-term measurements of the transport of African mineral dust to the southeastern United States: implications for regional air quality. Journal of Geophysical Research 104, 15917-15927.

Prospero, J.M., Carlson, T.N., 1972. Vertical and areal distribution of Saharan dust over the western equatorial North Atlantic Ocean. Journal of Geophysical Research 77, 5255-5265.

Prospero, J.M., Nees, R.T., 1977. Dust concentration in the atmosphere of the equatorial North Atlantic: possible relationship to the Sahelian drought. Science 196, 1196-1198.

Prospero, J.M., Nees, R.T., 1986. Impact of the North African drought and El Nino on mineral dust in the Barbados trade winds. Nature 320, 735-738.

Prospero, J.M., Nees, R.T., 1987. Deposition rate of particulate and dissolved aluminum derived from Saharan dust in precipitation at Miami, Florida. Journa of Geophysical Research 92, 14723-14731.

Prospero, J.M., Lamb, P.J., 2003. African droughts and dust transport to the Caribbean: climate change implications. Science 302, 1024-1027.

Prospero, J.M., Glaccum, R.A., Nees, R.T., 1981. Atmospheric transport of soil dust from Africa to South America. Nature 289, 570-572.

Prospero, J.M., Bonatti, E., Schubert, C., Carlson, T.N., 1970. Dust in the Caribbean atmosphere traced to an African dust storm. Earth and Planetary Science Letters 9, 287-293.

Prospero, J.M., Ginoux, P., Torres, O., Nicholson, S.E., Gill, T.E., 2002. Environmental characterization of global sources of atmospheric soil dust identified with the Nimbus 7 Total Ozone Mapping Spectrometer (TOMS) absorbing aeroso product. Reviews of Geophysics 40, 1002. http://dx.doi.org/10.1029/ 2000RG000095.

Prospero, J.M., Charlson, R.J., Mohnen, V., Jaenicke, R., Delany, A.C., Moyers, J., Zoller W., Rahn, K., 1983. The atmospheric aerosol system: an overview. Reviews of Geophysics and Space Physics 21, 1607-1629.

Pye, K., 1987. Aeolian Dust and Dust Deposits. Academic Press, San Diego, CA, 334 pp.

Pye, K., 1995. The nature, origin and accumulation of loess. Quaternary Science Reviews 14, 653-657.

Ratmeyer, V., Fischer, G., Wefer, G., 1999. Lithogenic particle fluxes and grain size distributions in the deep ocean off northwest Africa: implications for seasona changes of aeolian dust input and downward transport. Deep-Sea Research I 46 1289-1337.

Rea, D.K., 1990. Aspects of atmospheric circulation: the late Pleistocene (0$950,000 \mathrm{yr}$ ) record of eolian deposition in the Pacific Ocean. Palaeogeography, Palaeoclimatology, Palaeoecology 78, 217-227.

Rea, D.K., 1994. The paleoclimatic record provided by eolian deposition in the deep sea: the geologic history of wind. Reviews of Geophysics 32 159-195.

Rea, D.K., 2007. Eolian records, deep-sea sediments. In: Elias, S. (Ed.), The Encyclopedia of Quaternary Sciences. Elsevier, Amsterdam, pp. 643-649.

Rea, D.K., Snoeckx, H., Joseph, L.H., 1998. Late Cenozoic eolian deposition in the North Pacific: Asian drying, Tibetan uplift, and cooling of the Northern Hemisphere. Paleoceanography 13, 215-224.

Reheis, M.C., 2003. Dust deposition in Nevada, California, and Utah, 1984-2002. US Geological Survey Open-File Report 03-138, version 1.0. <http://pubs.usgs.gov/ of/2003/ofr-03-138/>.

Reheis, M.C., 2006. A 16-year record of eolian dust in Southern Nevada and California, USA: controls on dust generation and accumulation. Journal of Arid Environments 67, 487-520.

Reheis, M.C., Kihl, R., 1995. Dust deposition in southern Nevada and California, 1984-1989: relations to climate, source area, and source lithology. Journal of Geophysical Research 100, 8893-8918.

Reheis, M.C., Budahn, J.R., Lamothe, P.J., 2002. Geochemical evidence for diversity of dust sources in the southwestern United States. Geochimica et Cosmochimica Acta 66, 1569-1587.

Reheis, M.C., Budahn, J.R., Lamothe, P.J., Reynolds, R.L., 2009. Compositions of modern dust and surface sediments in the Desert Southwest, United States. Journal of Geophysical Research 114, F01028. http://dx.doi.org/10.1029/ 2008JF001009.

Reheis, M.C., Goodmacher, J.C., Harden, J.W., McFadden, L.D., Rockwell, T.K., Shroba R.R., Sowers, J.M., Taylor, E.M., 1995. Quaternary soils and dust deposition in southern Nevada and California. Geological Society of America Bulletin 107, 1003-1022.

Revel-Rolland, M., De Dekker, P., Delmonte, B., Hesse, P., Magee, J.W., BasileDoelsch, I., Grousset, F., Bosch, D., 2006. Eastern Australia: a possible source of dust in East Antarctica interglacial ice. Earth and Planetary Science Letters 249, $1-13$.

Rex, R.W., Syers, J.K., Jackson, M.L., Clayton, R.N., 1969. Eolian origin of quartz in soils of Hawaiian islands and in Pacific pelagic sediments. Science 163, $277-$ 279.

Reynolds, R., Belnap, J., Reheis, M., Lamothe, P., Luiszer, F., 2001. Aeolian dust in Colorado Plateau soils: nutrient inputs and recent change in source. Proceedings of the National Academy of Sciences of the United States of America 98, 71237127.
Roberts, H.M., 2008. The development and application of luminescence dating to loess deposits: a perspective on the past, present and future. Boreas 37, 483507.

Roberts, H.M., Muhs, D.R., Bettis III, E.A., 2007. North America. In: Elias, S. (Ed.), The Encyclopedia of Quaternary Sciences. Elsevier, Amsterdam, pp. 1456-1466.

Roberts, H.M., Muhs, D.R., Wintle, A.G., Duller, G.A.T., Bettis III, E.A., 2003. Unprecedented last glacial mass accumulation rates determined by luminescence dating of loess from western Nebraska. Quaternary Research 59, 411-419.

Rognon, P., Coudé-Gaussen, G., Revel, M., Grousset, F.E., Pedemay, P., 1996. Holocene Saharan dust deposition on the Cape Verde Islands: sedimentological and $\mathrm{Nd}-\mathrm{Sr}$ isotopic evidence. Sedimentology 43, 359-366.

Romero, O.E., Kim, J.-H., Donner, B., 2008. Submillennial-to-millennial variability of diatom production off Mauritania, NW Africa, during the last glacial cycle. Paleoceanography 23, PA3218. http://dx.doi.org/10.1029/2008PA001601.

Rossignol, J., Moine, O., Rousseau, D.-D., 2004. The Buzzard's Roost and Eustis mollusc sequences: comparison between the paleoenvironments of two sites in the Wisconsinan loess of Nebraska, USA. Boreas 33, 145-154.

Rousseau, D.-D., Kukla, G., 1994. Late Pleistocene climate record in the Eustis loess section, Nebraska, based on land snail assemblages and magnetic susceptibility. Quaternary Research 42, 176-187.

Rousseau, D.-D., Derbyshire, E., Antoine, P., Hatté, C., 2007. Europe. In: Elias, S. (Ed.), The Encyclopedia of Quaternary Sciences. Elsevier, Amsterdam, pp. 1440-1456.

Rousseau, D.-D., Wu, N., Guo, Z., 2000. The terrestrial mollusks as new indices of the Asian paleomonsoons in the Chinese loess plateau. Global and Planetary Change 26, 199-206.

Ruddiman, W.F., 1997. Tropical Atlantic terrigenous fluxes since 25,000 yrs BP. Marine Geology 136, 189-207.

Ruhe, R.V., 1967. Geomorphic surfaces and surficial deposits in southern New Mexico. New Mexico Bureau of Mines and Mineral Resources Memoir 18, 65 p.

Ruhe, R.V., 1969. Quaternary Landscapes in Iowa. Iowa State University Press, Ames, Iowa, 255 pp.

Ruth, U., Bigler, M., Röthlisberger, R., Siggaard-Andersen, M.-L., Kipfstuhl, S., GotoAzuma, K., Hansson, M.E., Johnsen, S.J., Lu, H., Steffensen, J.P., 2007. Ice core evidence for a very tight link between North Atlantic and east Asian glacial climate. Geophysical Research Letters 34. http://dx.doi.org/10.1029/ 2006 GL027876.

Sarnthein, M., Tetzlaff, G., Koopman, B., Wolter, K., Pflaumann, U., 1981. Glacial and interglacial wind regimes over the eastern subtropical Atlantic and North-West Africa. Nature 293, 193-196.

Schaetzl, R.J., Anderson, S., 2005. Soils: Genesis and Geomorphology. Cambridge University Press, Cambridge, $817 \mathrm{pp}$

Schirrmeister, L., Kunitsky, V., Grosse, G., Wetterich, S., Meyer, H., Schwamborn, G., Babiy, O., Derevyagin, A., Siegert, C., 2011. Sedimentary characteristics and origin of the Late Pleistocene Ice Complex on north-east Siberian Arctic coastal lowlands and islands - a review. Quaternary International 241, 3-25.

Schwanghart, W., Schütt, B., 2008. Meteorological causes of Harmattan dust in West Africa. Geomorphology 95, 412-428.

Shackleton, N.J., Opdyke, N.D., 1976. Oxygen-isotope and paleomagnetic stratigraphy of Pacific core V28-239 late Pliocene to latest Pleistocene. Geological Society of America Memoir 145, 449-464.

Shao, Y., Wyrwoll, K.-H., Chappell, A., Huang, J., Lin, Z., McTainsh, G.H., Mikami, M., Tanaka, T.Y., Wang, X., Yoon, S., 2011. Dust cycle: an emerging theme in Earth system science. Aeolian Research 2, 181-204.

Singer, M.J., Verosub, K.L., 2007. Mineral magnetic analysis. In: Elias, S. (Ed.), The Encyclopedia of Quaternary Sciences. Elsevier, Amsterdam, pp. 2096-2102.

Singhvi, A.K., Porat, N., 2008. Impact of luminescence dating on geomorphological and palaeoclimate research in drylands. Boreas 37, 536-558.

Smalley, I.J., 1966. The properties of glacial loess and the formation of loess deposits. Journal of Sedimentary Petrology 36, 669-676.

Smalley, I.J., 1995. Making the material: the formation of silt-sized primary mineral particles for loess deposits. Quaternary Science Reviews 14, 645-651.

Smalley, I.J., Vita-Finzi, C., 1968. The formation of fine particles in sandy deserts and the nature of 'desert' loess. Journal of Sedimentary Petrology 38, 766-774.

Smalley, I.J., O'Hara-Dhand, K., Wint, J., Machalett, B., Jary, Z., Jefferson, I., 2009. Rivers and loess: the significance of long river transportation in the complex event-sequence approach to loess deposit formation. Quaternary International 198, 7-18.

Smith, B.J., Wright, J.S., Whalley, W.B., 2002. Sources of non-glacial, loess-size quartz silt and the origins of "desert loess". Earth-Science Reviews 59, 1-26.

Spell, T.L., McDougall, I., 1992. Revisions to the age of the Brunhes-Matuyama boundary and the Pleistocene geomagnetic polarity timescale. Geophysical Research Letters 19, 1181-1184.

Stein, R., Sarnthein, M., 1984. Late Neogene events of atmospheric and oceanic circulation offshore northwest Africa: high-resolution record from deep-sea sediments. Palaeoecology of Africa and the Surrounding Islands 16, 9-36.

Strausberg, M.J., Wang, H., Richardson, M.I., Ewald, S.P., Toigo, A.D., 2005 Observations of the initiation and evolution of the 2001 Mars global dust storm. Journal of Geophysical Research 110, E02006. http://dx.doi.org/10.1029/ 2004JE00236.

Stuut, J.-B.W., Lamy, F., 2004. Climate variability at the southern boundaries of the Namib (southwestern Africa) and Atacama (northern Chile) coastal deserts during the last 120,000 yr. Quaternary Research 62, 301-309.

Stuut, J.-B.W., Kasten, S., Lamy, F., Hebbeln, D., 2007. Sources and modes of terrigenous sediment input to the Chilean continental slope. Quaternary International 161, 67-76. 
Stuut, J.-B.W., Prins, M.A., Schneider, R.R., Weltje, G.J., Jansen, J.H.F., Postma, G., 2002. A 300-kyr record of aridity and wind strength in southwestern Africa: inferences from grain-size distributions of sediments on Walvis Ridge, SE Atlantic. Marine Geology 180, 221-233.

Stuut, J.-B., Zabel, M., Ratmeyer, V., Helmke, P., Schefuß, E., Lavik, G., Schneider, R., 2005. Provenance of present-day eolian dust collected off NW Africa. Journal of Geophysical Research 110, D04202. http://dx.doi.org/10.1029/2004JD005161.

Sugden, D.E., McCulloch, R.D., Bory, A.J.-M., Hein, A.S., 2009. Influence of Patagonian glaciers on Antarctic dust deposition during the last glacial period. Nature Geoscience 2, 281-285.

Sun, D., Shaw, J., Zhisheng, A., Minyang, C., Leping, Y., 1998. Magnetostratigraphy and paleoclimatic interpretation of a continuous 7.2 Ma Late Cenozoic sediments from the Chinese Loess Plateau. Geophysical Research Letters 25, 85-88.

Sun, J., 2002a. Source regions and formation of the loess sediments on the high mountain regions of northwestern China. Quaternary Research 58, 341-351.

Sun, J., 2002b. Provenance of loess material and formation of loess deposits on the Chinese Loess Plateau. Earth and Planetary Science Letters 203, 845-859.

Sun, J., Zhu, X., 2010. Temporal variations in Pb isotopes and trace element concentrations within Chinese eolian deposits during the past $8 \mathrm{Ma}$ : implications for provenance change. Earth and Planetary Science Letters 290, $438-447$.

Sun, J., Zhang, M., Liu, T., 2001. Spatial and temporal characteristics of dust storms in China and its surrounding regions, 1960-1999: relations to source area and climate. Journal of Geophysical Research 106, 10325-10333.

Swap, R., Garstang, M., Greco, S., Talbot, R., Kallberg, P., 1992. Saharan dust in the Amazon Basin. Tellus 44B, 133-149.

Tanaka, K.L., Scott, D.H., Greeley, R., 1992. Global stratigraphy. In: Kieffer, H.H. Jakosky, B.N., Snyder, C.W., Matthews, M.S. (Eds.), Mars. Arizona, University of Arizona Press, Tucson, pp. 345-382.

Taylor, S.R., McLennan, S.M., 1985. The Continental Crust: Its Composition and Evolution. Blackwell Scientific Publications, Oxford, $312 \mathrm{pp}$.

Tegen, I., 2003. Modeling the mineral dust aerosol cycle in the climate system. Quaternary Science Reviews 22, 1821-1834.

Tetzlaff, G., Peters, M., 1986. Deep-sea sediments in the eastern equatorial Atlantic off the African coast and meteorological flow patterns over the Sahel. Geologische Rundschau 75, 71-79.

Thompson, L.G., Davis, M.E., Mosley-Thompson, E., Sowers, T.A., Henderson, K.A. Zagorodnov, V.S., Lin, P.-N., Mikhalenko, V.N., Campen, R.K., Bolzan, J.F., ColeDai, J.F., Francou, B., 1998. A 25,000-year tropical climate history from Bolivian ice cores. Science 282, 1858-1864.

Thompson, L.G., Mosely-Thompson, E., Davis, M.E., Lin, P.-N., Henderson, K.A., ColeDai, J., Bolzan, J.F., Liu, K.-B., 1995. Late glacial stage and Holocene tropical ice core records from Huascarán, Peru. Science 269, 46-50.

Thompson, L.G., Mosley-Thompson, E., Davis, M.E., Bolzan, J.F., Dai, J., Yao, T., Gundestrup, N., Wu, X., Klein, L., Xie, Z., 1989. Holocene-Late Pleistocene climatic ice core records from Qinghai-Tibetan Plateau. Science 246, 474-477.

Tjallingii, R., Claussen, M., Stuut, J.-B.W., Fohlmeister, J., Jahn, A., Bickert, T., Lamy, F., Röhl, U., 2008. Coherent high- and low-latitude control of the northwest African hydrological balance. Nature Geoscience 1, 670-675.

Tsoar, H., Pye, K., 1987. Dust transport and the question of desert loess formation. Sedimentology 34, 139-153.

Vallelonga, P., Gabrielli, P., Balliana, E., Wegner, A., Delmonte, B., Turetta, C., Burton, G., Vanhaecke, F., Rosman, K.J.R., Hong, S., Boutron, C.F., Cescon, P., Barbante, C., 2010. Lead isotopic compositions in the EPICA Dome C ice core and Southern Hemisphere Potential Source Areas. Quaternary Science Reviews 29, 247-255.

Velichko, A.A., Bogucki, A.B., Morozova, T.D., Udartsev, V.P., Khalcheva, T.A. Tsatskin, A.I., 1984. Periglacial landscapes of the East European Plain. In: Velichko, A.A., Wright, H.E., Jr., Barnosky, C.W. (Eds.), Late Quaternary Environments of the Soviet Union. University of Minnesota Press, Minneapolis, pp. 94-118.

Velichko, A.A., Morozova, T.D., Nechaev, V.P., Rutter, N.W., Dlusskii, K.G., Little, E.C., Catto, N.R., Semenov, V.V., Evans, M.E., 2006. Loess/paleosol/cryogenic formation and structure near the northern limit of loess deposition, East European Plain, Russia. Quaternary International 152 (153), 14-30.

Verosub, K.L., Fine, P., Singer, M.J., TenPas, J., 1993. Pedogenesis and paleoclimate: interpretation of the magnetic susceptibility record of Chinese loess-paleosol sequences. Geology 21, 1011-1014.
Von Suchodoletz, H., Kühn, P., Hambach, U., Dietz, M., Zöller, L., Faust, D., 2009. Loess-like and palaeosol sediments from Lanzarote (Canary Islands/Spain) indicators of palaeoenvironmental change during the Late Quaternary. Palaeogeography, Palaeoclimatology, Palaeoecology 278, 71-87.

Wada, T., Chikita, K.A., Kim, Y., Kudo, I., 2011. Glacial effects on discharge and sediment load in the subarctic Tanana River Basin, Alaska. Arctic, Antarctic, and Alpine Research 43, 632-648.

Wan, S., Li, A., Clift, P.D., Stuut, J.-B.W., 2007. Development of the East Asian monsoon: mineralogical and sedimentologic records in the northern South China Sea since 20 Ma. Palaeogeography, Palaeoclimatology, Palaeoecology 254, 561-582.

Wang, X., Dong, Z., Zhang, J., Zhao, A., 2002. Relations between morphology, air flow, sand flux and particle size on transverse dunes, Taklimakan Sand Sea, China. Earth Surface Processes and Landforms 27, 515-526.

Washington, R., Todd, M., Middleton, N.J., Goudie, A.S., 2003. Dust-storm source areas determined by the total ozone monitoring spectrometer and surface observations. Annals of the Association of American Geographers 93, 297-313.

Wells, P.V., Stewart, J.D., 1987. Cordilleran-boreal taiga and fauna on the central Great Plains of North America, 14,000-18,000 years ago. American Midland Naturalist 118, 94-106.

Weltje, G.J., Prins, M.A., 2003. Muddled or mixed? Inferring palaeoclimate from size distributions of deep-sea clastics. Sedimentary Geology 162, 39-62.

Wieder, M., Gvirtzman, G., Porat, N., Dassa, M., 2008. Paleosols of the southern coastal plain of Israel. Journal of Plant Nutrition and Soil Science 171, 533-541.

Winckler, G., Anderson, R.F., Fleisher, M.Q., McGee, D., Mahowald, N., 2008. Covariant glacial-interglacial dust fluxes in the equatorial Pacific and Antarctica. Science 320, 93-96.

Wintle, A.G., 2008. Luminescence dating: where it has been and where it is going. Boreas 37, 471-482.

Wolff, E.W., Chappellaz, J., Blunier, T., Rasmussen, S.O., Svensson, A., 2010. Millennial-scale variability during the last glacial: the ice core record. Quaternary Science Reviews 29, 2828-2838.

Wright, J.S., 2001a. "Desert" loess versus "glacial" loess: quartz silt formation, source areas and sediment pathways in the formation of loess deposits. Geomorphology 36, 231-256.

Wright, J., 2001b. Making loess-sized quartz silt: data from laboratory simulations and implications for sediment transport pathways and the formation of 'desert' loess deposits associated with the Sahara. Quaternary International 76 (77), 719.

Wright, J., Smith, B., 1993. Fluvial comminution and the production of loess-sized quartz silt: a simulation study. Geografiska Annaler 75A, 25-34.

Wright, J., Smith, B.J., Whalley, W.B., 1998. Mechanisms of loess-sized quartz silt production and their relative effectiveness: laboratory simulations. Geomorphology 23, 15-34.

Xiao, J., Inouchi, Y., Kumai, H., Yoshikawa, S., Kondo, Y., Liu, T., An, Z., 1997. Eolian quartz flux to Lake Biwa, Japan, over the past 145,000 years. Quaternary Research 48, 48-57.

Xiao, J.L., An, Z.S., Liu, T.S., Inouchi, Y., Kumai, H., Yoshikawa, S., Kondo, Y., 1999. East Asian monsoon variation during the last 130,000 years: evidence from the Loess Plateau of central China and Lake Biwa of Japan. Quaternary Science Reviews 18 147-157.

Yaalon, D.H., Ganor, E., 1973. The influence of dust on soils during the Quaternary. Soil Science 116, 146-155.

Yung, Y.L., Lee, T., Wang, C.-H., Shieh, Y.-T., 1996. Dust: a diagnostic of the hydrologic cycle during the last glacial maximum. Science 271, 962-963.

Zárate, M.A., 2003. Loess of southern South America. Quaternary Science Reviews 22, 1987-2006.

Zárate, M.A., 2007. South America. In: Elias, S. (Ed.), The Encyclopedia of Quaternary Sciences. Elsevier, Amsterdam, pp. 1466-1479.

Zhou, S.Z., Jijun, L., Zhang, S.Q., Zhao, J.D., Cui, J.X., 2004. Quaternary glaciations in China. In: Ehlers, J., Gibbard, P.L. (Eds.), Quaternary Glaciations-Extent and Chronology, Part III. Elsevier, Amsterdam, pp. 105-113.

Zurek, R.W., Martin, L.J., 1993. Interannual variability of planet-encircling dust storms on Mars. Journal of Geophysical Research 98, 3247-3259. 